\title{
Bases para o estudo da genética de po- pulações dos Hymenoptera em geral e dos Apinae sociais em particular $r^{(*)}$
}

\author{
WARWICK E. KERR
}

Livre Docente e Assistente da Cadeira de Citologia e Genética Geral da Escola Superior de Agricultura "Luiz de Queiroz" Universidade de São Paulo

(*) Entrégúe pará a publicação em 1 de Março de 1950.

(**) Ţese pạra concurso para obtenção do título de Livre Bocente, apressentada à .Escola Superior de Agricultura "Luiz de Queiroz", em 30 de Janeiro de 1950 e defendida em 17 de Junho de 1950 . 


\section{fNDICE}

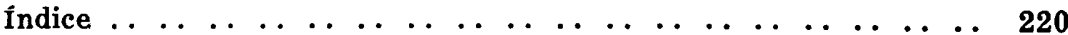

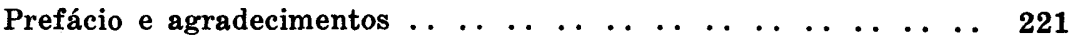

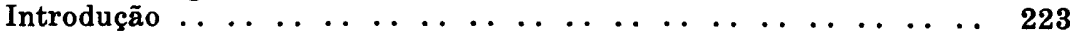

1. Parte : Modelos matemáticos . . . . . . . . . . . . . . 224

I - Processos básicos de reprodução $\ldots \ldots \ldots$. . . . . . . . . $\quad 225$

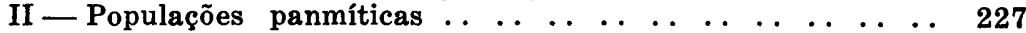

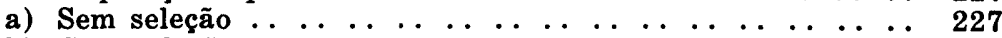

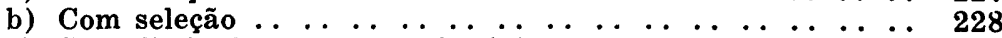

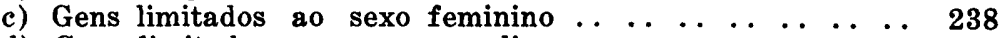

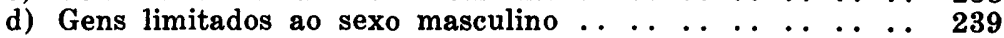

e) Duração do ciclo biológico - Fator tempo $\ldots \ldots \ldots \ldots$

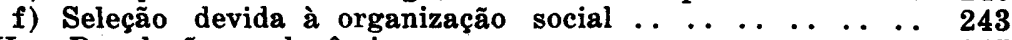

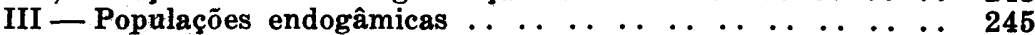

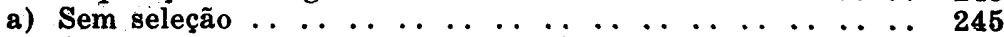

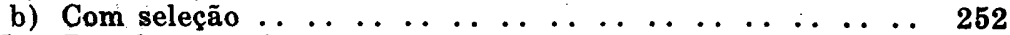

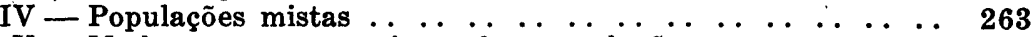

$\mathrm{V}$ - Mudanças no mecanismo de reprodução ... . . . . . . 265

$2^{a}$. Parte - Informações biológicas sôbre os Apinae sociais, es-

pecialmente sôbre os Meliponini, necessárias ao estudo parti-

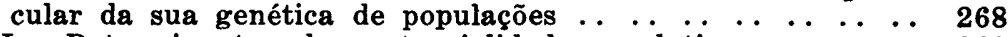

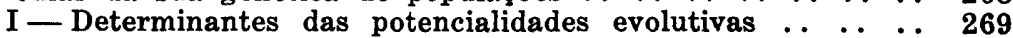

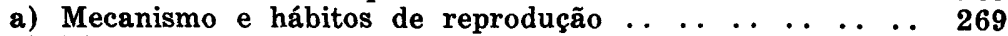

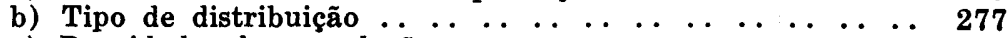

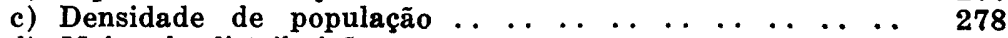

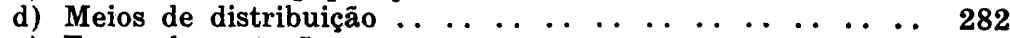

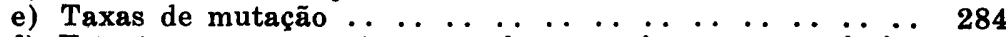

f) Estrutura e comportamento do mecanismo cromossômico 288

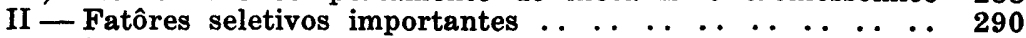

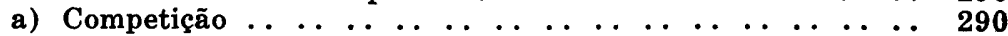

b) Predação $\ldots \ldots \ldots \ldots \ldots$

$3^{\text {a }}$. Parte - Consideraçōes gerais . . . . . . . . . . . . . . . 301

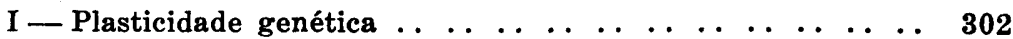

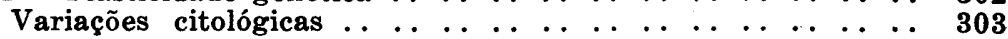

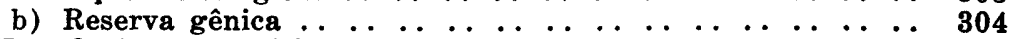

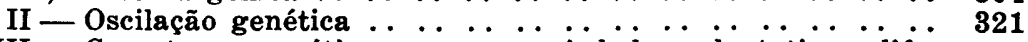

III - Caracteres genéticos com propriedades adaptativas diferentes $\ldots \ldots \ldots \ldots \ldots \ldots$

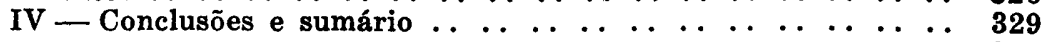

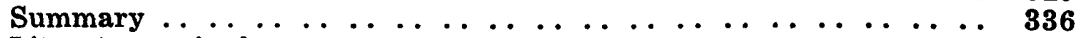

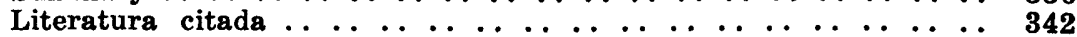

Explicação das figuras . . . . . . . . . . . . . . . . . . . . . . . 350

Explicação dos gráficos $\ldots \ldots \ldots \ldots \ldots$ 


\section{PREFACIO E AGRADECIMENTOS}

A primeira sugestão que nos levou a pesquisar o terreno da genética de populações nos himenópteros veio-nos de uma série de aulas especializadas versando sôbre o assunto da genética em populações, ministradas pelo Prof. F. G. B.ieger no período de 26-3-48 a 21-5-48. Nesse mesmo tempo iniciámos nossos estudos, que se foram ampliands até chegar ao ponto em que os apresentamos agora.

Para a execução da primeira parte dêstes estudos tivemos a orientação constante e segura do Pl zf. F. G. Erieger. Aproveitamos esta oportunidade ímpar para demonstrar a nossa gratidâo ao Prof. F. G. Brieger, decicando-lhe êste trabalho.

Querem:ss consignar ao Prof: Th. I) ibzhansky nossos agradecimentos po: várias sugestões feitras e aprovejtadas por nós nesta tese.

Para conseguir parte das informações biológicas contidas nesta tese, tivemos de fazer duas viagens, uma, ao Norte do país, (Maranhão, Pará e Amapá), de 10-10-48 a 5-11-48, e outra, ao Oeste, na região do Sul de Mato Grosso e Bolívia, de 22-6-49 a 22-7-49. Para a primeira dessas viagens tivemos o auxílio imprescindível do Prof. José de Mello Moraes, DD. Diretor da Escola Superior de Agricultura "Luiz de Queiroz", do Prof. F. G. Brieger e do Dr. Paulo Nogueira Neto; para a segunda, tivemos, além das citadas autoridades, o apôio do Dr. José T. A. Gurgel, que, na ocasião, substituia o Prof. F. G. Brieger. Em Belém, Pará, tivemos as maiores atenções do Dr. Felisberto de Camargo e do Dr. George O'Neill Addison que tornaram nossa viagem ao Norte a mais proveitosa possível. Com o auxílio e apresentações do Major Jorge de Arruda Proença pudemos estender nossa viagem ao Norte, até a frontiira com a Guiana Francêsa, no Território Federal do Amapá. A todos êstes senhores, os nossos sinceros agradecimentos.

Exceptuando-se umas poucas espécies, quase tôdas as nossas abelhas, tanto sociais como solitárias, foram classificadas pelo Revmo. Pe. Jesus Santiago Moure, C. M. F., a quem, mais uma vez, somas agradecidos.

Necessitámos, para diversas experiências, de numerosas colónias de Melipona marginata LEPELETIER e Melipona quadrifasciata LEPELETIER. Para tanto, recebemos um inestimável auxílio de noss o pai. Sr. Américo Caldas Kerr, que nos conseguiu, entre os seus empregados e amigos, um número de colônias dessas duas espécies, o que nos seria impossivel de outra 
forma; deixamos-lhe, portanto, registrados, nossos grandes agradecimentos por tal apôio.

$\mathrm{Na}$ tarefa de conseguir material fomos auxiliados grandemente pelo nosso amigo Dr. Paulo Nogueira Neto, que, de tempos em tempos, nos enviou colônias preciosas para os nossos estudos. Assim, pudemos verificar os tipos de $M$. quadrifasciata LEPELETIER existentes em Goiaz e em Santa Catarina, e estudar uma subespécie de $M$. marginata LEPELETIER de Santa Catarina, por colônias que nos enviou.

Para o levantamento da distribuição geográfica da espécie Melipona quadrifasciata LEPELETIER necessitámos de amostras de operárias de diversas zonas. Devemos nossos agradecimentos aos Srs.: Dr. Nilson Ramos Righi, que nos enviou amostras de Avaré; Dr. Carlos Ventura Cerqueira, que nos enviou de Salvador, Bahia; Dr. A. da Costa Lima que nos permitiu estudar sua coleção, com exemplares do Estado do Rio de Janeiro; Dr. Frederico Lane, que nos permitiu observar a coleção do Departamento de Zoologia, de onde coletámos, aproximadamente, a metade das anotações; Dr. Lauro Travassos, que nos permitiu observar a coleção do Inst. Osvaldo Cruz; Dr. Eduardo Navajas, que nos facilitou os estudos da coleção do Inst. Biológico; Pe. Jesus Santiago Moure, C. M. F., que nos enviou os dados da sua enorme coleção; Dr. Paulo Nogueira Neto, que nos remeteu informações de Campinas e abelhas de Pariquera-Assú, Brotas, Cafelândia (E. S. Paulo), Piracanjuba (E. de Goiáz) \& Taunay (Santa Catarina); Sr. Teodoro Mendes, que nos mandou exemplares de Três Lagoas (Mato Grosso); Sr. David de Paiva Cortes, que nos facilitou a aquisição de material de Poços de Caldas (Minas Gerais) e arredores; Sr. Antonio Loiola Junqueira e Dr. Osmani Junqueira, que puseram à nossa disposição colmeias de S. José do Rio Pardo (E. São Paulo); Dr. Helio Monfrinato, que nos trouxe exemplares de colônias de Ipanema (E. S. Paulo).

Pela oportunidade de coletar abelhas na zona servida pela Estrada de Ferro Brasil-Bolívia devemos favores aos Srs.: Dr. José Bardauil, Rachid Bardauil, Wadib Bardauil e Dr. M. da Silva Torres; os três primeiros Senhores e mais o $\mathbf{S r}$. José Xavier facilitaram-nos a obtenção de abelhas de Corumbá (Mato Grosso) e arredores; por essa cooperação estendemos-lhes nossos agradecimentos.

Somos gratos ao Dr. H. Osorno, de Bogotá, Colômbia, por nos ter enviado da sua região, exemplares de fêmeas e machos de·Bombus rubicundus SMITH.

Somos obrigados aos Dr. Liders Pareja e Dr, Osvaldo Pa- 
reja pelas facilidades que nos proporcionaram em Santa Cruz de la Sierra, Bolívia, e ao primeiro pミlo envio de abelhas dos arredores dessa cidade.

Deixamos, também, os nossos agradecimentos ao nosso amigo Sr. Estêvão Barroso por diversas colônias de meliponíneos que nos forneceu, especialmente por uma colônia híbrida de Trigona Plebeia mosquito F. SMITH que nos foi de muita valia. Também, por exemplares de uma colônia híbrida entre duas subespécies de Melipona quadrifasciata LEPELETIER somos gratos ao Sr. Schiller Torres.

Na primeira parte de nossa tese tivemos, na resolução de alguns problemas, o auxílio precioso do Dr. Frederico Pimentel Gomes, a quem agradecemos.

Agradecemos ao Dr. Charles D. Michener, Chairman of Department, Kansas University, pela autorização de transcrevermos um quadro de sua publicação "Notes on the habits of some Panamanian stingless bees (Hymenoptera, Apidade)".

Ao Prof. Silvio de Souza agradecemos o auxílio que nos deu executando a revisão gramatical dêste trabalho.

Aos amigos Sr. João Zandoval, Sr. Walter Bortolazzo, Sr. Sebastião Coelho Fischer, Sr. Adalberto Gorga e Sr. Oswaldo Perez agradecemos o interêsse e esforços dispendidos na confecção dêste trabalho.

Em diversas partes da execução desta tese tivemos o auxilio inestimável de nossa espôsa Lygia F. S. Kerr, tanto datilografando os originais como organizando a bibliografia e outros detalhes; per tudo isso e pelo seu grande apôio moral, somos-lhe imensamente gratos.

Aos Drs. Lindolfo Guimarães e Prof. Salvador de Toledo Piza Jr. consignamos nossos agradecimentos por informáações sôbre nomenclatura de aves e mamiferos e literatura científica.

Durante e após a defesa desta tese recebemos sugestões dos membros da banca examinadora que nos foram de muita utilidade, e portanto somos agradecidos.

\section{INTRODUÇAOO}

Em nossa tese para doutoramento (1947) fizemos um estudo geŕal sôbre o gênero Melipona, tendo aproveitado as conclusões para traçarmos um esquema para a evolução do gênero. Esse estudo final sôbre a evolução foi feito sôbre as seguintes bases: determinação das castas, bionomia, fósseis, distribuição geográfica, anatomia interna e externa e variação intra-especffica. claro que um estudo dessa natureza não po- 
de ser generalizado e nem dêle podemos tirar conclusóes para outros grupos de Hymenoptera. Não podemos, também, evidenciar quais os mecanismos seguidos nos seus processos de evolução e especiação.

Resolvemos, portanto, pesquisar quais as fórmulas teóricas que uma determinada população de himenópteros teria de obedecer, conhecidos os seus métodos de reprodução e outros dados biológicos. O nosso problema é, então, o de aplicar os conhecimentos de genética de populações para o caso especial dos Hymenoptera, que com o seu sistema reprodutivo haplo-diplóide, afasta-se extraordinariamente da diplóidia comumente encontrada entre os animais. Nas segunda e terceira partes dêste trabalho colecionamos diversos dados importantes para o estudo da genética de populações dos Apinae sociais.

O único trabalho que, até o momento em que escrevemos esta tese, veio ter às nossas mãos e que trata, sob alguns aspectos, da aplicação de modelos matemáticos à genética de população em himenópteros, é o de $H$. Kalmus e C. A.B. Smith (1948): "Production of pure lines in bees", baseado, essencialmente, em duas publicações de Haldane $(1936,1937)$. Sôbre êsse estudo de Kalmus e Smith nos reportaremos diversas vezes na primeira parte desta tese.

A nomenclatura dos Meliponini que adotámos para agrupamentos superiores a gênero consta do trabalho de Michener (1944). Para o gênero Melipona (ILLIGER) seguimos o trabalho de Schwarz (1932), aceitando as modificaçōes sugeridas por Moure e Kerr (1950). Para o gênero Trigona (JURINE) e Lestrimelitta (FRIESE) utilizamo-nos de denominações genéricas e subgenéricas de Schwarz (1948), com excepções nos seguintes sub-gêneros: Friesella (MOURE), Tetragonisca (MOURE), e Schwarzula (MOURE), em que concordamos com as denominações subgenéricas de Moure (1946 a e b).

\section{1a. Parte}

\section{MODELOS MATEMATICOS}

Ultimamente tem-se desenvolvido muito o ramo da genética de populações que procura encontrar esquemas matemáticos que correspondam às situações genéticas encontradas em diversos organismos através de um grande número de gerações. Assim, vemos os estudos de Dobzhansky, Paterson e outros em Drosophila, de Brieger e Crow em milho, Dahlberg em 
populações humanas, de Lerner em galinhas e outros, e os que estudaram êsse problema sob um ponto de vista mais geral, como Sewall Wright, Fischer, Haldane, Hogben, Mather e outros. Para podermos elaborar alguns esquemas matemáticos para as populações de himenópteros, temos, em primeiro lugar, que examinar qual o processo de reprodução do grupo.

\section{I - PROCESSOS BÁSICOS DE REPRODUÇÃO}

Em tôdas as deduções que serão feitas nesta tese não levaremos em conta a poliembrionia; também nos restringiremos, devido ao maior interêsse que apresentam, do ponto de vista da genética de populações, aos himenópteros arrenótocos.

Temos que considerar dois processos básicos de reprodução: endogamia e panmixia. Endogamia - quando o acasalamento se dá obrigatoriamente entre parentes; Panmíxia quando o acasalamento é completamente livre.

Tanto um como outro processo pode ser afetado por diversos fatôres, como, por exemplo:

1) para endogamia: postura de duas fêmeas num mesmo hospedeiro, fêmea fecundada ocasionalmente, após abandonar o hospedeiro, por macho estranho (ambos se aplicam a himenópteros parasitas), enxames sincrônicos (formigas), etc.

2) Para panmixia: Distâncias e densidade relativa de populações, número de machos por colmeia, maior probabilidade dos machos irmãos fecundarem a rainha virgem, etc...

Chamamos tipo de reprodução mista quando ambos os processos básicos citados são afetados por diversos fatôres que introduzem, na endogamia e na panmixia, respectivamente, uma taxa de fecundação livre ou uma taxa de endogamia. Pensamos serem dêste tipo os casos mais frequentes entre os Hymenoptera.

A endogamia dá-se em alguns himenópteros parasitas como Telenomus fariai LIMA, estudado por Dreyfus e Breuer (1944), e Melittobia chalybii ASMEAD estudado por Schmieder (1938), Whiting (1947) e Schmieder e Whiting (1947) onde as fêmeas são fecundadas por seus irmãos dentro, ainda, da vitima que parasitaram. Também temas verificado que nas enxameações de Atta sp. é relativamente raro haver enxames sincrônicos dentro da área em que as içás são fecundadas, dando-se portanto, a endogamia.

A panmixia é encontrada em diversos himenópteros superiores. Assim, entre algumas abelhas solitárias, segundo fo- 
mos informados pelo especialista da matéria, Pe. J. S. Moure C. M. F., os machos, quando se tornam adultos, abandonam o sítio em que nasceram e não voltam mais, indo esperar as fêmeas nas flores da pređileção do grupo. Confirmando essa observação, vimos, em Janeiro de 1949, muitos machos de Halictidae esperando as fêmeas em flores de Portulaca oleracea L.

Em muitas espécies do gênero Anthidium, os machos esperam as fêmeas dentro das flores de Anthirrinum, majus L. Em diversos Anthophoridae os machos esperam as fêmeas dentro de Convolvalaceae. Nêstes casos, é claro que a panmixia é práticamente total.

Nos himenópteros sociais, a não ser em colônias isoladas, a reprodução é mista, com maior porcentagem de panmixia. E' sabido que uma operária de Apis mellifera LINNAEUS, a não ser em condições muito particulares, (sendo nova e bem alimentada), não tem permissão de entrar em colónia que não seja a sua. Porém, o mesmo não se dá com os machos dessa espécie, que possuem um livre trânsito em tôdas as colmeias, principalmente naquelas em que está prestes a nascer uma rainha. Assim, é fato conhecido dos apicultores, que uma colônia com rainha e sem muitos machos se encherá de uma legião dêstes em poucos dias, após matarmos a rainha.

O mesmo observámos em Melipona. Em uma colônia de Melipona quadrifasciata anthidioides LEP., que houvera ficado órfã de rainha, notámos, dentro e fora da colmeia, diversos exemplares de $M$. quadrifasciata quadrifasciata LEP. Suspeitando de saque, coletámos algumas dessas abelhas e verificámos serem machos que, portanto, tiveram livre entrada à colmeia que dêles ia necessitar. Verificámos, também, em colónias de $M$. quadrifasciata LEP., um ardil utilizado pelos machos para terem acesso a qualquer colônia da sua espécie. Vão ter às flores, onde se empoam de pólen, e, depois, procuram entrar em qualquer colmeia, o que com facilidade conseguem. E' sabido que operárias carregadas de pólen geralmente não são impedidas de entrar em colônias estranhas da mesma espécie, e êsse mesmo processo é utilizado pelos machos, para poderem introduzir-se em diversas colmeias.

Apesar de o processo de reprodução ser aparentemente panmítico, verificaremos, no fim dêste trabalho, que, devido à baixa densidade de população dos Meliponini deverá, forçosamente, haver uma certa taxa de endogamia. Se não houver outra colmeia num raio de 3 a 7 quilómetros aproximadamente, dever-se-á processar a endogamia, porém, nas nossas matas, essa situação não é muito comum. Do processo generalizado de 
reprodução dos Meliponini, vamos cuidar, com mais detalhe, na segunda parte.

\section{II - POPULAÇÕES PANMITICAS}

Entre os himenópteros sociais o processo de reprodução é misto, porém com predominância de panmixia. Temos, porisso, grande interêsse em conhecer as regras que regem as populações panmíticas.

Desconsideraremos, nesta parte, a possibilidade da ocor.rência de novas mutações ou da existência de uma taxạ de migração, para facilitar os cálculos.

\section{a) Sem seleção}

Sewall Wright, em diversas de suas publicações, aconselha-nos a estudar genética de populações em modêlos bastante simples, para podermos tirar conclusões apreciáveis.

Suporemos, portanto, uma população totalmente heterozigota para um par de gens onde teremos fêmeas Aa e machos $\mathrm{A}$ e a. $\mathrm{Na}$ 1a. geração, teremos :

$$
\begin{aligned}
& \mathrm{Aa} \times \mathrm{A}=\uparrow \uparrow \mathrm{AA}+\mathrm{Aa} ; \delta \mathrm{A}+\mathrm{a} \\
& \mathrm{Aa} \times \mathrm{a}=\varnothing q \mathrm{Aa}+\mathrm{a} ; \delta^{\star} \delta \mathrm{A}+\mathrm{a}
\end{aligned}
$$

Portanto, somando, teremos:

$$
\begin{aligned}
P_{1} \text { } \bigcirc & =\frac{1}{4} \mathrm{AA}+\frac{2}{4} \mathrm{Aa}+\frac{1}{4}, \mathrm{aa} \\
ठ^{\top} & =\frac{1}{2} \mathrm{~A}+\frac{1}{2} \mathrm{a}
\end{aligned}
$$

Passemos, agora, ao cálculo da segunda geração. Levaremos em conta a segregação gônica da população, pois todos os gônes têm oportunidades iguais de unir-se : 
Segregação gônica dos machos : $\frac{1}{2} \mathrm{~A}+\frac{1}{2} \mathrm{a}$

Segregação gônica das fêmeas : $\left\{\begin{array}{l}\frac{1}{4} \mathrm{~A}+\frac{1}{4} \mathrm{~A}=\frac{1}{2} \mathrm{~A} \\ \frac{1}{4} \mathrm{a}+\frac{1}{4} \mathrm{a}=\frac{1}{2} \mathrm{a}\end{array}\right.$ ração :

Combinando êsses gônes entre si, teremos a segunda ge-

$$
\mathrm{P}_{2}\left\{\begin{array}{l}
q q=\frac{1}{4} \mathrm{AA}+\frac{2}{4} \mathrm{Aa}+\frac{1}{4} \mathrm{aa} \\
\sigma^{\top}=\frac{1}{2} \mathrm{~A}+\frac{1}{2} \mathrm{a}
\end{array}\right.
$$

O mesmo acontecerá para as populações subseqüentes; vemos, por aí, que as populações panmíticas de himenópteros seguem perfeitamente o teorema de Hardy-Weinberg, e, portanto, sua fórmula geral poderia ser escrita da seguinte maneira, indicando as freqüências gônicas dos gens com as letras $\mathrm{p}$ e $\mathrm{q}$ :

$$
\begin{aligned}
& f q=\mathrm{p}^{2}(\mathrm{AA})+2 \mathrm{pq}(\mathrm{Aa})+\mathrm{q}^{2}(\mathrm{aa}) ; \delta \delta=p \\
& (\mathrm{~A})+\mathrm{q} \text { (a) ou, se seguirmos a maneira de Brieger } \\
& \text { (1948), empregando as letras u, v e w para as fre- } \\
& \text { qüências zigóticas: }
\end{aligned}
$$

$$
\begin{aligned}
& q Q=\left(u+\frac{v}{2}\right)^{2} \mathrm{AA}+2\left(\mathrm{u}+\frac{\mathrm{v}}{2}\right)\left(\mathrm{w}+\frac{\mathrm{v}}{2}\right)(\mathrm{Aa})+\left(\mathrm{w}+\frac{\mathrm{v}}{2}\right)^{2}(\mathrm{aa}) \\
& \delta \sigma=\left(\mathrm{u}+\frac{\mathrm{v}}{2}\right) \mathrm{A}+\left(\mathrm{w}+\frac{\mathrm{v}}{2}\right) \mathrm{a} \\
& \text { b) Com seleção }
\end{aligned}
$$

Para entrarmos neste assunto precisamos decidir sôbre 
a nomenclatura e processo que determinem o valor de seleção a ser utilizado.

Examinemos algumas delas :

1) Sewall Wright (1931) utiliza-se como índices de seleção, dos seguintes valores : 1 para os homozigotos dominantes, (1-s) para os homozigotos recessivos e (1-hs) para os heterozigotos.

Achamos muito razoável êsse método de dar ao "gên selvagem" o valor unitário, porém, para não complicar as operações matemáticas com o aparecimento de valores assimétricos, não o seguiremos.

2) Wright, num rodapé (pg. 102) da mesma publicação de 1931, sugere uma forma mais simétrica, concluindo que as razões da reprodução dos três genotípos sejam (*) :

\section{homozigoto dominante: 1 - $S_{A}$ heterozigoto :1 \\ homozigoto recessivo : $1-S_{0}$}

3) Fisher (1930, pg. 100) supõe que as três fases de uma população aparecem, em uma geração qualquer, na razão p2 : 2pq : $\mathrm{q}^{2}$, e que suas vantagens seletivas relativas estão respectivamente na razão a : b : c, e portanto as três fases, nessa geração, reproduzir-se-ão segundo a razão ap2 : $2 \mathrm{bpq}$ : $\mathrm{cq}^{2}$ sendo que no equilíbrio teremos

$$
\frac{p}{q}=\frac{b-c}{b-a}
$$

Este método que achamos melhor que os precedentes, foi simplificado por Brieger, como veremos em seguida.

4) Brieger $(1948,1950)$ admite que, se houver seleção, o número de indivíduos ficará reduzido de uma certa fração, e a população restante se tornará :

$$
\mathrm{xAA}+\mathrm{yAa}+\mathrm{zaa}
$$

onde $\mathrm{x}, \mathrm{y}$ e $\mathrm{z}$ têm o mesmo sentido dos índices $\mathrm{a}, \mathrm{b}$ e $\mathrm{c}$ de Fisher. Para dar as frequências em função dos heterozigotos, Brieger dividiu todos os termos por $\mathrm{y}$, dando, portanto:

$$
\frac{x}{y}(A A)+\frac{y}{y}(A a)+\frac{z}{y}(a a)
$$

(*) Mais tarde, Wright substituiu os valores SA por \& e Sa por $t$ que, evidentemente, facilitou a grafia das fórmulas. 
Ao valor $\frac{x}{y}$ chamou RA e ao valor $\frac{z}{y}$ chamou $R$. Tais va-

Iores de sobrevivência podem ser maiores ou menores que um, segundo a viabilidade dos homozigotos seja maior ou menor, em relação ao heterozigoto. Devido à simplicidade e às facilidades nos cálculos subseqüentes, adotámos esta última nomenclatura, se bem que não haja diferença de aplicação entre as fórmulas de Brieger, as de Fisher e as de Wright, pois :

$$
\begin{aligned}
& R_{A}=\frac{a}{b}=1-S_{A} \\
& R_{a}=\frac{c}{b}=1-S_{a}
\end{aligned}
$$

Os termos RA e Ra de Brieger são estimativas médias que incluem o resultado de todos os processos de seleção.

Queremos deixar claro, aquí, que os índices de sobrevivência $R A$ e $R a$ não estão relacionados com a dominância ou recessividade dos gens, mas sim com o maior ou menor valor da seleção. Por definição, RA será sempre o índice de sobrevivência do alele, dominante ou recessiv'o, menos sujeito à ação seletiva, ou seja, com maior capacidade adaptativa.

Não vamos admitir, inicialmente, diversas modalidades de alimentação (ou seleção) como o faz Brieger (reprodutiva e vegetativa, sendo ambas passíveis de mais subdivisões) para não complicarmos êste estudo; consideraremos, aquí, sòmente a eliminação de indivíduos após a fecundação da oosfera ("eliminação vegetativa" segundo Brieger, 1948).

Para encontrarmos uma fórmula bem geral suporemos inicialmente que os índices de sobrevivência das fêmeas sejam diferentes dos índices de sobrevivência dos machos. Assim teremos :

Indice de sobrevivência RA para fêmeas $A A$ Indice de sobrevivência 1 para fêmeas $\mathrm{Aa}$

fndice de sobrevivência $\mathrm{Ra}$ para fêmeas aa

fndice de sobrevivência R'A para machos A

Indice de sobrevivência $R$ 'a para machos a

sendo, portanto, todos os índices" tomados em relação a sobrevivência das fêmeas heterozigotas. 
Quando temos uma população panmítica de himenópteros, ideal, as fôrmulas gerais que a regem são:

$$
\begin{aligned}
& \left.\begin{array}{l}
q Q=p^{2}[A A]+2 p q[A a]+q^{2}[a d] \\
\delta^{\prime} \delta^{\prime}=p[A]+q[a]
\end{array}\right\} \text { Sem Seleçäo } \\
& \left.\begin{array}{l}
q q=P^{2} R_{A}[A A]+2 p q[A a]+q^{2} R_{a}[00] \\
\delta^{\prime} \sigma^{\prime}=P R_{A}^{\prime}[A]+q R_{0}^{\prime}[a]
\end{array}\right\} \text { com Selogäo }
\end{aligned}
$$

Para o cálculo das gerações subseaüentes teremos, sempre, que nos utilizar das segregações gônicas da geração anterior, isto é, tomar em consideracão a segregação mendeliana entre os óvulos produzidos por cada fêmea e a segregação entre os machos haploides e combiná-las. Do resultado que obtivermos, multiplicaremos os homozigotos por seus respectivos valores de seleção.

Interessam-nos, especialmente, quais serão as fórmulas de equílibrio para uma população de himenópteros com fecundação livre.

Encontramos, na literatura sôbre genética de populações, o tratamento de equilíbrio sob dois aspectos: - 1) quando todos os aleles existentes na geração inicial permanecem dentro da população nas gerações futuras e 2) quando os aleles existentes na geração inicial atigem valores constantes para a sua freqüencia. Parece-nos, porém, mais indicado, manter apenas a segunda condição, o que nos permitirá, como foi demonstrado por Brieger (1948), tratar todos os casos uniformemente. Assim, não importa que valores atingidos no equilibrio variem entre zero e qualquer valor positivo.

Para calcular as fórmulas do equilíbrio, utilizar-nos-emos da enézima e da $(n+1)$ geração de uma população, pois, se tivermos alcançado o equilíbrio, é claro que ambas serão iguais. Podemos, portanto, igualar suas gerações gônicas. Como aqui os machos são o produto da segregação gônica da $(n-1)$ população, não os conhecemos; porisso, chamaremos de $r$ e $s$ as frequências com que ocorrem os genótipos $A$ e $a$, entre us machos, sendo que $r+s=1$.

Assim temos : 


$$
\begin{aligned}
& \text { Gametas do geração } P_{n-1} \text { : } \\
& q q=p+q \quad \delta \delta=r+s \\
& \text { Zigotos da geraçäo } P_{n} \text { : } \\
& \text { onfes da seleçöo }\left\{\begin{array}{l}
q q=\operatorname{pr}[A A]+(p s+q r)[A a]+q s[0 a] \\
\delta \delta=p[A]+q[a]
\end{array}\right. \\
& \text { opós a seleçōo }\left\{\begin{array}{l}
q Q=p r \cdot R_{A}[A A]+(p s+q r)[A a]+q s \cdot R_{a}[0 \sigma] \\
\sigma \sigma=p \cdot R_{A}^{\prime}[A]+q \cdot R_{a}^{\prime}[a]
\end{array}\right. \\
& \text { Gameias da geração } P_{n} \text { : } \\
& q q=\left(p r \cdot R_{A}+\frac{p s+q r}{2}\right)[A]+\left(q s . R_{a}+\frac{p s+q r}{2}\right)|a| \\
& \delta \delta=p \cdot R_{A}^{\prime}[A]+q \cdot R_{0}^{\prime}[0] \\
& \text { No equilibrio: } \\
& \text { proporçōo de gamefos }\left[P_{n+1}\right]=\text { proporçöo de gamefos }\left|P_{n}\right|
\end{aligned}
$$

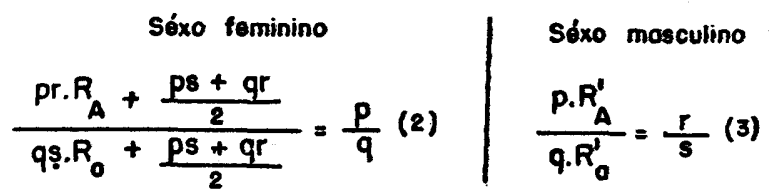

$$
\begin{aligned}
& r=\frac{p \cdot R_{A}^{\prime}}{p \cdot R_{A}^{\prime}+q \cdot R_{a}^{\prime}}(4) \cdot \text { tombem } s=\frac{q \cdot R_{a}^{\prime}}{p \cdot R_{A}^{\prime}+q \cdot R_{0}^{\prime}}(5)
\end{aligned}
$$




$$
\begin{aligned}
& \text { Substituindo } r \in S \text { em (2): } \\
& \frac{2 p \cdot R_{A} R_{A}^{\prime}+q\left(R_{A}^{\prime}+R_{a}^{\prime}\right)}{2 q \cdot R_{Q} R_{a}^{\prime}+q\left(R_{A}^{\prime}+R_{a}^{1}\right)}=1 \\
& \therefore 2 p \cdot R_{A} R_{A}^{\prime}-2 q \cdot R_{0} R_{0}^{\prime}+(q-p)\left(R_{A}^{\prime}+R_{0}^{\prime}\right)=0 \\
& q=1-p \\
& 2 p \cdot R_{A} R_{A}^{\prime}+2 p \cdot R_{a} R_{a}^{\prime}-2 R_{a} R_{0}^{\prime}+(t-2 p)\left(R_{A}^{\prime}+R_{0}^{\prime}\right)=0 \\
& \text { - } P=\frac{R_{A}^{\prime}+R_{a}^{\prime}-2 R_{a} R_{a}^{\prime}}{2\left(R_{A}^{\prime}+R_{a}^{\prime}-R_{A} R_{A}^{\prime}-R_{a} R_{a}^{\prime}\right)} \\
& q=\frac{R_{A}^{\prime}+R_{a}^{\prime}-2 R_{A} R_{A}^{\prime}}{2\left(R_{A}^{\prime}+R_{0}^{\prime}-R_{A} R_{A}^{\prime}-R_{a} R_{0}^{\prime}\right)} \\
& \therefore \frac{p}{q}=\frac{R_{A}^{\prime}+R_{a}^{\prime}-2 R_{a} R_{a}^{\prime}}{R_{A}^{\prime}+R_{a}^{\prime}-2 R_{A} R_{A}^{\prime}} \text { (8) }
\end{aligned}
$$

Para facilitar nossas considerações sôbre essas fórmulas de equilíbrio suporemos que os índices de sobrevivência das fêmeas sejam idênticos aos dos machos, isto é : RA $=$ R'A e $\mathrm{Ra}=\mathrm{R}$ "a. Assim as fórmulas (6) e (7) tornar-se-ão :

$$
\begin{aligned}
& P=\frac{R_{A}+R_{a}-2 R_{a}^{2}}{2\left(R_{A}+R_{0}-R_{A}^{2}-R_{0}^{2}\right)} \\
& q=\frac{R_{A}+R_{0}-2 R_{A}^{2}}{2\left(R_{A}+R_{0}-R_{A}^{2}-R_{0}^{2}\right)}
\end{aligned}
$$

Para o uso destas fórmulas devemos deixar mencionado que, quando seus numeradores ou denominadores adquirem valores inferiores a zero, elas deixam de ter significado biológico, pois, matematicamente, podemos obter resultados nega- 
tivos; porém, biologicamente, um determinado genotipo só pode descer até seu desaparecimento, isto é, até zero.

Agora que temos estas fórmulas, podemos considerar diversos casos, de acôrdo com o tipo de mutação ocorrido em determinado alele.

Podemos distinguir os seguintes casos: bilidade.

1) $\mathrm{RA}=\mathrm{Ra}=1$, "gens neutros", sem efeito sôbre a via-

2) $\mathrm{RA}=1>$ Ra. Se a mutação tiver índice de sobrevivência $R a$, teremos os "gens recessivos subviáveis", onde a viabilidade do híbrido não é afetada; se, porém, a mutação tiver índice de sobrevivência RA, teremos os "gens superviáveis dominantes", cujo híbrido terá o mesmo valor de sobrevivência que o homozigoto dominante.

3) $\mathrm{RA}>1>\mathrm{Ra}$. Também temos dois casos: quando a mutação tiver valor de sobrevivência Ra teremos os "gens subviáveis semi-dominantes", e, quando tiver valor de sobrevivência RA, teremos os "gens superviáveis semi-dominantes". Em ambos os casos, os heterozigotos terão viabilidade intermediária entre os dois homozigotos.

4) RA > $1=\mathrm{Ra}$. Teremos, quando o mutante tiver índice de sobrevivência $\mathrm{Ra}$, os "gens subviáveis dominantes", porém, se o índice de sobrevivência, for RA, teremos os "gens superviáveis recessivos".

5) $\mathrm{RA}>\mathrm{Ra}>1$ e 6) $\mathrm{RA}=\mathrm{Ra}>1$. Chamaremos a êsses tipos de mutantes, onde os híbridos possuem viabilidade inferior a ambos os homozigotos, de "gens de isolamento", pois, com acúmulo de gens desta natureza, teremos a dicotomia da população em duas espécies.

7) $1>\mathrm{RA} \geqq$ Ra. E' o caso dos "gens heteróticos", em que ambos os homozigotos apresentam índices de sobrevivência inferiores aos dos híbridos.

Estudaremos, agora, cada um desses casos, procurando aplicar, quando fôr necessário, as fórmulas (9) e (10) :

1) Quando $\mathrm{RA}=\mathrm{Ra}=1$

Ambos os aleles permanecem na população nas proporções iniciais (equilíbrio de Hardy-Weinberg), como ilustrado pelo gráfico 1, em que consideramos a frequiência inicial do gen A igual a $90 \%$ e de a $10 \%$.

2) Quando $\mathrm{RA}=1>\mathrm{Ra}$

Obtem-se o equilíbrio com o desaparecimento do gen menos viável. (veja no gráfico 2 que a tendência da curva de $A A$ (femeas) e de $A$ (machos) é alcançar $100 \%$ e a da curva de 
$a a$ e $a$ é alcançar zero). Esta é uma das situações em que nossa fórmula apresenta valores negativos; neste caso, $p$ apresentará um valor positivo e q um valor negativo; porém, como já nos referimos acima, o valor biológico de q não pode ser inferior a zero.

3) RA > $1>$ Ra. Neste caso, o gen menos viável será eliminado rapidamente, quaisquer que sejam as frequências iniciais. Ilustrando este caso construimos o Gráfico n.o 3.

4) $\mathrm{RA}>1=\mathrm{Ra}$. O gen com valor de sobrevivência $\mathrm{RA}$ suplantará seu aléle em poucas gerações, acabando por eliminálo completamente.

No gráfico 4 está ilustrado êste caso, onde verificamos a acentuada tendência de ser o gen a eliminado da população.

5) RA > Ra> 1. Aplicando as fórmulas (9) e (10), quando temos ambos os valores de $R$ superiores a 1 , verificamos que, tanto o numerador como o denominador tem valor negativo, dando-nos portanto um valor de equílibrio positivo. Para o caso dos gens heteróticos, que estudaremos mais adiante, podemos, dentro de certos limitミs, ter uma população inicial com qualquer proporção entre p e q, que será alcançado, ao fim de algumas gerações, um equilíbrio com todos os gens na população. Nêste caso, dos g€ns de isolamento, essa situação não acontece, pois, se a população inicial não estiver exatamente na proporção de equilíbrio teremos a eliminação do aléle cuja frequência estiver abaixo da frequência de equilíbrio.

Fizemos, para exemplificar êste caso, 3 gráficos em que RA é igual a 3 e $\mathrm{Ra}$ é igual a 2, sendo as proporções gênicas de equílibrio, para êste exemplo, as seguintes:

$$
p(A)=\frac{3}{16}, q(a)=\frac{13}{16}, r(A)=\frac{9}{35}, s(a) \frac{26}{35}
$$

No primeiro gráfico (gráfico 5) escolhemos uma frequência gênica inicial em que o gen mais viável (A) estivesse abaixo do equílibrio $(P=10 \%)$. Não obstante $c$ índice de sobrevivência de (A) ser superior ao de (a) nota-se que o alele A, ao fim de um certo número de gerações, será eliminado.

Isto vem dımonstrar que uma mutação para o gen de isolamento não tem chance de suplantar o seu alele, a não ser em populações muito pequenas, de um ou dois individuos por área reprodutiva, nas quais essa mutação poderá alcançar, no momento em que ocorrer, uma frequiência superior a do ponto de equilíbrio.

No segundo gráfico (gráfico 6) escolhemos exatamente as freqüências de equilíbrio, e podemos vêr que as gerações seguintes são sempre iguais as anteriores, dando, na represen- 
tação gráfica, uma linha reta, paralela ao eixo das ordenadas. Esta situação só pode ocorrer na zona de contato entre duas distribuições geográficas de subespécies adaptadas à condições ecológicas diferentes.

No gráfico 7 escolhemos um exemplo em que a freqüência inicial de A, o gen de maior índice de sobrevivência, seja maior que a frequência de equilíbrio $(\mathrm{P}=50 \%)$, demonstrando a rápida eliminação do alele menos adatado.

A razão pela qual o alele mais freqüente (em relação ao ponto de equilíbrio), suplanta o seu parceiro é por a variação nas gerações seguintes ser exponencial; assim sendo qualquer diferença pequena ficará exagerada em cada geração adicional.

6) Quando $\mathrm{RA}=\mathrm{Ra}>1$. E' um caso particular do que foi estudado sob o número 5. Aplicando as fórmulas 9 e 10 vemos que o ponto de equilíbrio é alcançado quando $\mathrm{p}=\mathrm{q}=\frac{1}{2}$ Portanto, se as frequências iniciais dos gens forem as mesmas, ambos os aléles se manterão na população; porém, se a frequência inicial de um fôr muito maior que a de outro, então o aléle menos freqüente será eliminado, como podemos vêr pelo seguinte esquema, substituindo RA e Ra por um valor qualquer maior que 1 no nosso caso tomámos o valor 2):

$\mathrm{P} 0 \mathrm{Q} Q=\left(\mathrm{p}^{2}\right) \mathrm{AA}+(2 \mathrm{pq}) \mathrm{Aa}+\left(\mathrm{q}^{2}\right) \mathrm{aa} ; \delta^{\top}=(\mathrm{p}) \mathrm{A}+(\mathrm{q}) \varepsilon$ $\mathrm{P} 1 \mathrm{q} q=\left(2 \mathrm{p}^{2}\right) \mathrm{AA}+(2 \mathrm{pq}) \mathrm{Aa}+\left(2 \mathrm{q}^{2}\right) \mathrm{aa}$;

$$
\sigma^{\pi} \sigma^{\pi}=(2 p) A+(2 q) a
$$

$\mathrm{P} 2$ 우 $=\left[2\left(2 \mathrm{p}^{3}+2 \mathrm{p}^{2}\right)\right] \mathrm{AA}+[6 \mathrm{pq}] \mathrm{Aa}+\left[2\left(2 \mathrm{q}^{3}+2 \mathrm{q}^{2}\right)\right]$ a $\sigma^{x}=\left[2\left(\mathrm{p}^{2}+\mathrm{q}\right)\right] \mathrm{A}+\left[2\left(\mathrm{q}^{2}+\mathrm{q}\right)\right] \mathrm{a}$

Vemos, por aí, que os valores de $p$ e $q$ variam exponencialmente; portanto, qualquer diferença entre êles será extremamente aumentada, acarretando a eliminação do alele inicialmente menos freqüente.

Fizemos um gráfico (gráfico 8) para exemplificar a situação dêste caso quando a freqüência de um gen for maior que a de outro. Verificamos pelas curvas de a, que êsse alele, de frequiência inicial menor, será rapidamente eliminado.

Pelo que vimos acima, um gen de isolamento em uma população estática, só tem chance de sobrevivência eliminando seu alele; concluimos que, para haver acúmulo de gens dessa natureza, de modo que venham a formar uma nova espécie, necessário se torna um isolamento geográfico ou ecológico. 
7) 1 > RA > Ra. o caso dos gens heteróticos, que vêm sendo muito estudados ultimamente devido a seu alto valor a plasticidade genética de uma população. Em populações diploides panmíticas é já sabido que tais gens permanecem, em todos os seus aleles, nas populações, atingindo proporções fixas entre os genotipos. Também para populações com autofecundação obrigatória foi demonstrado (Brieger, 1948) que teremos situação idêntica quando ambos os gens heteróticos possuirem índices de sobrevivência para ambos os genotipos homozigotos, inferiores a $\mathbf{0 , 5}$.

Estudando o caso dos gens heteróticos para populações panmíticas de himenópteros, chegámos ao seguinte resultado: ambos os gens permanecerão indefinidamente na população em proporções determinadas entre os tais genotipos, desde que os valores de RA não sejam muito maiores que $R a$.

$$
\text { quando } \begin{aligned}
& R_{A}+R_{a}-2 R_{A}^{2}=0 \\
& \frac{P}{q}=\frac{R_{A}+R_{0}-2 R_{a}^{2}}{R_{A}+R_{0}-2 R_{A}^{2}}=\infty
\end{aligned}
$$

teremos na população sòmente o gen mais viável, sendo eliminado o gen com índice de seleção igual a $R a$.

Porisso, para cada determinado valor de Ra, temos determinado limite de variação para RA, que podemos calcular resolvendo a equação do segundo grau:

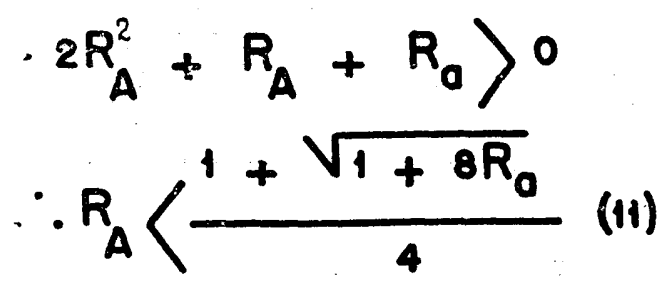

sendo que a outra raiz não nos interessa, por ser negativa. Usando sòmente a fórmula com raiz positiva, podemos calcular para cada valor de $\mathrm{Ra}$, um valor limitante para RA.

Determinaremos, como exemplo, para alguns valores de $\mathrm{Ra}$, qual o valor máximo que pode ter RA, para que ambos os gens se conservem na população: 


$$
\begin{array}{ll}
\mathrm{Ra}=0,90 \mathrm{RA}<0,96 & \mathrm{Ra}=0,40 \mathrm{RA}<0,76 \\
\mathrm{Ra}=0,80 \mathrm{RA}<0,93 & \mathrm{Ra}=0,30 \mathrm{RA}<0,71 \\
\mathrm{Ra}=0,70 \mathrm{RA}<0,89 & \mathrm{Ra}=0,20 \mathrm{RA}<0,65 \\
\mathrm{Ra}=0,60 \mathrm{RA}<0,85 & \mathrm{Ra}=0,10 \mathrm{RA}<0,63 \\
\mathrm{Ra}=0,50 \mathrm{RA}<0,81 & \mathrm{Ra}=0,00 \mathrm{RA}<0,50
\end{array}
$$

Com estas considerações podemos dizer que, em populações panmíticas de himenópteros, devido ao mecanismo haplodiploide que rege seu sistema sexual-nuclear, para cada valor de Ra haverá um valor máximo de RA, o qual, se for ultrapassado, acarretará a eliminação do gen menos viável.

Ilustrámos o caso dos gens heteróticos com dois gráficos:

Gráfico 9 - em que o valor de RA está dentro do limite imposto pela fórmula 11. Verificamos que os diversos genotipos mantem-se dentro da população tendendo assintóticamente para seus limites de equilibrio.

Gráfico 10 - 0 valor de RA escolhido $(0,9)$ é acima de seu limite $(0,71)$ e o resultado é que o gen a tende a ser rápidamente eliminado.

c) Gens limitados ao sexo feminino

Quando temos gens limitados a um dos sexos, a formula de equilíbrio muda-se, dando resultados bastante diferentes coniorme seja limitado ao sexo feminino ou masculino. Fstudemos, primeiramente, o caso que consideramos mais importante entre os Hymenoptera: os gens limitados ao sexo feminino.

Neste caso a dedução das fórmulas para o equilíbrio segue a mesma marcha inicialmente como no caso das fórmulas (2) e (5). Porém temos agora para o equilíbrio a seguinte proporção entre os gametas dos machos:

$$
\therefore \frac{r}{s}=\frac{p}{q} \therefore \frac{r}{s+r}=\frac{p}{p+q}
$$

Logo: $r=p$, e igualmente, $s=q$

Fazendo a proporção com os gametas das fêmeas e substituindo $\mathbf{r}$ por $\mathbf{p}$ e $\mathbf{s}$ por $\mathbf{q}$ temos: 


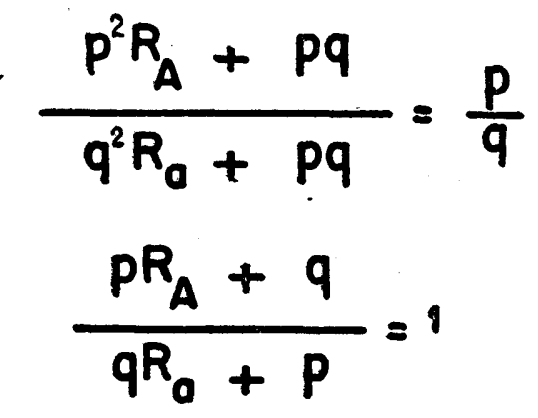

Daí extraimos as fórmulas do equilibrio para gens limitados ao sexo em populações de himenópteros com fecundação cruzada:

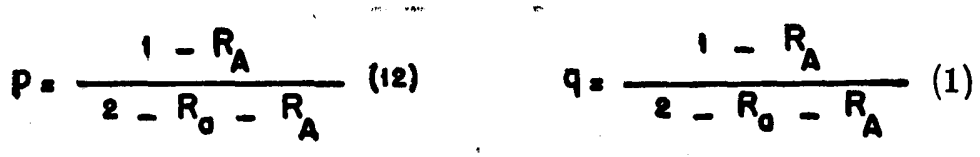

portanto, igual ao equilíbrio das populações diploides com fecundação cruzada. Tôdas as consideraçōes concernentes a essa fórmula já foram discutidas por Fischer (1930) e por Brieger (1948), para populações diploides e aplicam-se, integralmente, ao caso de gens limitados ao sexo feminino em popu-

lações panmiticas de himenópteros, com a diferença que, no caso dos himenópteros, os valores tendem para os limites um pouco mais lentamente.

d) Gens limitados ao sexo masculino

Consideraremos, aquí, os gens que possuem os seus efeitos ou a sua seleção, limitados aas machos.

Tomando por base as equações entre as geraçōes Pn e Pn+1, teremos:

(1) Uma outra maneira de derivar as fórmulas (12) e (13) é igualando R'A e R'a a um nas fórmulas (6) e (7). 


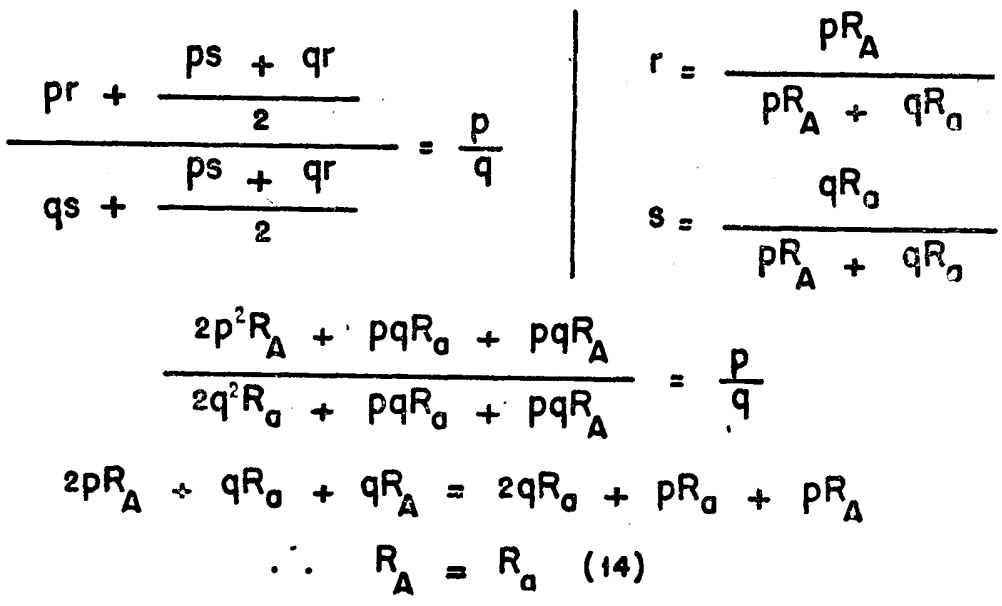

Portanto, a condição essencial para que dois aleles (A) e (a) permaneçam na população, quando forem limitados, em seus efeitos seletivos, ao sexo masculino, é que seus respectivos valores de sobrevivência (RA) e (Ra) sejam iguais entre si, podendo ser menores, iguais ou maiores que a unidade. $\mathrm{E}^{\prime}$ facil de ver que a maioria dos gens limitados a sexo masculino deverão ser monotípicos, ou mantidos pela pressão de novas mutações devido ao fato de serem raras as mutações de aleles com idêntico valor de sobrevivência.

e) Duração do ciclo biológico - Fator tempo

Temos visto, nas diversas publicações que manuseámos sôbre o assunto da genética de populações, pouca ou nenhuma referência sôbre o fator tempo relacionado com o coeficiente de seleção, em termos da duração das diferentes fases do ciclo biológico de um indivíduo. Achamos, no entanto, que, para o caso de indivíduos com vida adulta relativamente muito longa, êsse fator não deve ser desprezado. E, para o caso especial dos himenópteros sociais, êsse fator tem muita importância devido a dois pontos:

1) A fase adulta das fêmeas férteis dos himenópteros sociais é extremamente maior que a fase preadulta, exagerando 
- que acontece em outros organismos, como podemos verificar, comparando:

a) o homem - fase adulta aproximadamente 2 vezes maior que a pré-adulta.

b) Drosophila melanogaster MEIGEN - fase adulta aproximadamente 3 vezes maior que a fase pré-adulta.

c) Mamíferos - fase adulta é, na maioria dos casos, aproximadamente 4 a 7 vezes maior que a fase pré-adulta.

d) Apis melifera L. e alguns Meliponini (rainha) - fase adulta de 30 a 50 vezes maior que a fase pré-adulta. Apesar dos machos durarem poucas semanas, para efeito da genética de populações, sua vida é tão longa quanto a da rainha, devido ao fato de sua carga de espermatozoides ser depositada na espermatica daquela, enquanto a mesma durar.

Deveríamos aquí, para proceder a uma comparação de dados mais homogêneos, relatar a duração da vida de sutras abelhas, para verificar se há tendência de, nas espécies mais evoluidas, a vida dos indivíduos férteis ser mais longa. Infelizmente não temos dados neste sentîto.

2) Os fatôres de seleção atingirão o genótipo menos viável de maneira um tanto mais favorável nas populações de himenópteros sociais, que nas populações diplóides, como verificaremos em um exemplo concréto, mais abaixo.

Brieger (1948) considera $R$ como sendo o valor de sobrevivência final, passível de ser dividido em duas classes, sendo o valor de $\mathbf{R}$ o produto das duas classes. Assim, $\mathbf{R v} \times \mathbf{R r}=\mathbf{R}$, onde $R v$ é o valor de sobrevivência vegetativa e $R r$ o valor de sobrevivência reprodutiva. Por sua vez, Rv pode ser subdividido em diversas porções, de acôrdo com o organismo:

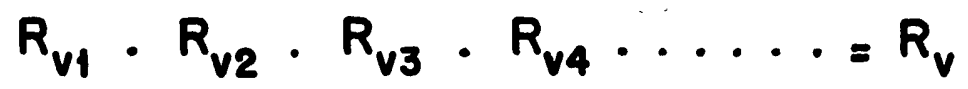

Para o caso especial dos apíneos sociais, podemos considerar Rv1 x Rv2 x Rv3 = Rv onde Rv1 representa o índice de seleção na fase larval, Rv2 na fase pupal e Rv3 na fase adulta. Como as larvas e pupas das fêmeas dos Apini e Meliponini são criados em células isoladas, admitamos que Rv1 e Rv2 sejam iguais a 1 devido a seleção ser desprezível, ao contrário do que acontece com outros organismos, como a Drosophila, por exemplo, em que a competição entre larvas já foi demonstrada (Dobzhansky 1947, pg. 148). A seleção na fase adulta deve ser 
relacionada a uma unidade de tempo; assim, a fórmula nossa se tornará:

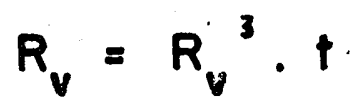

pois a seleção caracterizada pelo índice Rv3, num segundo período de tempo (t), se dará sôbre os indivíduos que restam do primeiro período. Num terceiro período de tempo dar-se-á sôbre os indivíduos que restaram do segundo, e assim por diante.

Assim, o valor de Rv3 será, para nós, o índice de seleção na unidade de tempo, supondo, para simplificar os cálculos, que os valores de Rv3, em anos seguidos, sejam da mesma ordem.

Ainda para o caso dos apíneos sociais achamos que a unidade de tempo para a fase adulta deve ser um ano, pois só no fim de um ano se completará um ciclo das variações climáticas, pelas quais os himenópteros sociais, como a maioria dos organismos, são muito a fetados.

Vejamos um exemplo prático da importância dêsse fator tempo: Suponhamos que, para um par de aleles, tenhamos: RAv3 $=0,90$ e Rav3 $=0,70$ e que a nossa unidade de tempo seja um ano.

Se os genótipos AA, Aa e aa estiverem em concorrência apenas durante um ano, os valores de $R v$ seriam iguais aos de Rv3 e o equilíbrio para o qual "tenderia" a população seria alcançado com a eliminação do genotipo menos viável devido ao valor máximo permitido a $R A$ ser 0,89 , neste caso de $R a=0,70$.

Se os genótipos AA, Aa e aa, estiverem em concorrência por dois anos, os valores de $R v$ seriam:

$$
\mathrm{RAV}=(0,90)^{2}=0,81 ; \mathrm{RaV}=(0,70)^{2}=0,49
$$

e o equilíbrio para o qual tenđeria a população seria, também, a eliminação do genótipo menos viável, pois, para $\mathrm{Ra}=0,49 \mathrm{o}$ valor máximo permitido a RA para termos ambos os gens na população é 0,805 .

Se o tempo fôr 3 anos, os valores de Rv serão:

$$
\mathrm{RAV}=(0,90)^{3}=0,729 \quad \mathrm{RaV}=(0,70)^{3}=0,343
$$

em que já haverá equilíbrio, pois quanđo $R a=0,343, \mathrm{RA}$ deverá ter um valor inferior a 0,74 (segurdo nossa fórmula (11) para que todos os genótipos permaneçam na população. Assim o equilíbrio para o qual tenđeria a população seria, agora: 


$\mathrm{AA}=0,978557$
$\mathrm{Aa}=0,021327$
aa $=0,000116$$\quad$ ou, após a seleção, $\quad \begin{aligned} & \mathrm{AA}=0,978557 \times 0,729 \\ & \mathrm{Aa}=0,021327 \times 1,000 \\ & \text { aa }=0,000116 \times 0,343\end{aligned}$

Talvez um fator desta natureza possa ter influenciado umá seleção favorável no sentido de prolongação da vida dos organismos haplodiploides culminando com os apíneos sociais em que a vida adulta é extremamente longa, quando comparada com a pré-adulta.

\section{f) Seleção devido à organização social}

Nos himenópteros sociais a rainha sofre dois tipos de seleção: uma, individual, que chamaremos de $\mathrm{Ri}$ (índice de sobrevivência individual) e outra, devido à sua progênie, social. que chamaremos de Rs, (índice de sobrevivência devido à sua progênie) sendo o índice de sobrevivência global :

$\mathrm{R}=\mathrm{Ri} \times \mathrm{Rs}$. (16)

Êsse fator Rs, por sua vez, é o produto de duas classes de seleção: Rrs, que é a eliminação devida às diferentes capacidades de postura dos diversos genótipos das rainhas e Rvs, que é devida às diferentes capacidades de trabalho dos diversos genótipos de operárias.

Se os gens heteróticos tiverem um grande papel nos himenópteros sociais, como parece, teremos a seguinte situação: as rainhas e operárias $\mathrm{AA}^{\prime}$ serão melhores que as rainhas e operárias, os heterozigotas AA ou A'A'. Vamos considerar um terceiro alele, A", fazendo que AA', A'A" e A"A tenham valor seletivo igual a um, e os homozigotos, quaisquer índices de sobrevivência inferiores a um.

Portanto, se essa hipótese for satisfeita, teremos maior viabilidade nas colônias de combinação tipo $\mathrm{AA}^{\prime} \times \mathrm{A}^{\prime}$, em que tanto operárias como rainhas serão heterozigotas, vindo. em segundo lugar os tipos $\mathrm{AA}^{\prime} \mathrm{x}$ A (rainhas e metade das operárias heterozigotas), em terceiro os tipos $\mathrm{AA} \times \mathrm{A}^{\prime}$ (rainha homozigota e operárias heterozigotas) e, em último, combinações tipo AA x A (rainha e operárias serão homozigotas). Uma tal situação já foi reconhecida pelos melhoristas norteamericanos de Apis mellifera L., que, para produzirem colônias híbridas com máxima produtividade, cruzam uma linhagem pura (AA) com outra (A'A') para obter descendentes híbridos (AA'). As colméias assim obtidas conterão operárias ativas e fortes devido à sua heterose, porém, pouco numerosas devido ao fato de as rainhas dessas colmeias serem ainda puras (AA). 
As rainhas virgens heterózigotas (AA') produzidas por essa colméia são, por sua vez, cruzadas com machos de uma terceira linhagem pura (A"A"), resultando colméias com rainhas híbridas (A'A) e operárias híbridas (A'A") e AA"). Com êsse sistema foi obtido um estoque altamente produtivo, que deu uma média de $120 \mathrm{~kg}$. de mel disponível por colméia (Farrar, 1947, pg. 684).

O método seguido por Farrar, Mackensen e Roberts (em Farrar 1947, pg. 683) corresponde, exatamente, ao processo de híbridos triplos em milho, em que os descendentes do primeiro cruzamento são heteróticos; porém, seu número é relativamente pequeno, pois provem de sementes de espigas produzidas ainda nas plantas das linhas puras, igualmente como as operárias no primeiro cruzamento citado. são descendentes de uma rainha de linhagem pura. No $2^{\circ}$. cruzamento, do milho híbrido como fêmea com uma terceira linhagem pura, obteremos, agora sementes híbridas em plantas híbridas.

O processo chamado "híbrido duplo", em milho, que resulta da combinação de 4 linhagens puras, não pode ser imitido nas abelhas, em virtude da natureza haploide dos machos,

Nos detalhes biológicos, porém, os dois casos (milho e a abelha) não são idênticos. No milho, precisamos de um indivíduo mãe, muito robusto, que produza bastante sementes, e descendentes semelhantes ou mais fortes. Nas abelhas, precisamos de uma rainha híbrida, para ser bastante prolífica, e, na mesma colónia, necessitamos de operárias robustas em número suficiente para bem alimentar a colméia. Poderiamos considerar a colméia como um organismo social, atribuindo-lhe seus próprios índiceś de sobrevivência, definidos. agora, em relação à sociedade e não à rainha individual. Precisaríamos dos mesmos índices que já mencionámos no início, isto é, um índice (Rrs) que meça o número de ovos produzidos e outro (Rsv) que meça a atividade das operárias; em terceiro lugar, necessitariamos de rainhas com altos índices de sobrevivência (Ri).

A sobrevivência total para uma colméia seria, portanto, o produto de todos os índices parciais sendo o seu máximo, para gens heteróticos, por definição, o valor um. Esse valor poderá ser um, só quando todos os índices parciais forem por sua vez iguais a um, isto é, quando todos os componentes de uma colméia, sem excepção, forem heterozigotos (excepto os machos que não entram em discussão).

Podemos aventar a hipótese de que tal sistema (AA' $x$ A"), sendo freqüente em uma espécie selvagem, favorecerá a existência de numerosos aléles múltiplos. 


\section{III -POPULAÇÕES ENDOGÂMICAS}

a) Sem seleção

Suporemos, inicialmente, para facilidade de compreensão, ${ }_{1}^{u m a}$ população $(\mathrm{Po})$ que dê uma segregação gônica $\left(\frac{1}{2} \mathrm{~A}\right.$ e - a).

2

Lembraremos, ainda, que os machos dos himenopteros são haploides (excetuando-se poucos casos), oriundos por arrenotoquia. Portanto, temos que separar os machos e as fêmeas para efeito de cálculo.

Como estamos adiante de uma população inicial (Po) híbrida e endogâmica, teremos, dentro de uma mesma vítima (lagarta, ovo, etc.), fêmeas Aa e machos $\mathrm{A}$ e a. A primeira geração (P1) de fêmeas resultantes dêsse acasalamento será :

$\frac{1}{4} \mathrm{AA}+\frac{2}{4} \mathrm{Aa}+\frac{1}{4}$ aa (veja o Quadro I), ao passo que a geração de machos corresponderá à segregação gônica das fêmeas, portanto: $\frac{1}{2} \mathrm{~A}+\frac{1}{2}$ a.

Como cada fêmea escolhe uma vítima própria para sua desova, temos de considerar cada progênie em separado, segundo o seu tipo de acasalamento, para o cálculo da segunda 1 geração (P2). Assim $\frac{1}{4} \mathrm{AA}$ (fêmeas) podem acasalar-se com machos $\mathrm{A}$ ou a, porém, só produzirão machos $\mathrm{A}$, devido à sua segregação gônica (2a. coluna do Quadro I). Colocando em linhas seguidas as vítimas parasitadas, segundo os acasalamentos, teriamos :

$$
\begin{aligned}
& { }^{\circ} O=\frac{1}{8} \mathrm{AA}+\frac{1}{8} \mathrm{Aa} ; \quad \delta^{x}=\frac{1}{4} \mathrm{~A} \\
& { }^{\circ}=\frac{1}{8} \mathrm{AA}+\frac{2}{8} \mathrm{Aa}+\frac{1}{8} \mathrm{aa} ; \delta^{\top}=\frac{1}{4} \mathrm{~A}+\frac{1}{4} \text { ? } \\
& q q=\frac{1}{8} \mathrm{Aa}+\frac{1}{8} \mathrm{aa} ; \quad \cdots \quad \sigma^{x}=\frac{1}{4} \mathrm{Aa}
\end{aligned}
$$


Prosseguindo assim, completamos o Quadro I, seguindo sempre, o processo indicado pelas flexas; vemos que poderão existir 7 tipos de acasalamentos, sendo que os únicos que não segregam são os das extremidades marginais do Quadro I.

Como podemos verificar pelo Quadro I, temos, nas 5 colunas centrais, nos numeradores, diversas sucessões, cuja lei de formação verificamos ser $\mathrm{An}=\mathrm{An}-1+\mathrm{An}-2$, porém, como não nos foi possível determinar o termo geral por indução, entregámos o problema ao Dr. Frederico Pimentel Gomes, Livre Docente da Cadeira de Matemática, que nos disse estarmos diante da "sucessão de Fibonacci" e, por sua indicação, encontramos as fórmulas dessa sucessão no livro de Hogben (1946). Tendo a fórmula da sucessão da coluna central, foi-nos fácil calcular os outros termos em questão que se encontram na penúltima linha do Quadro $I$.

Nesse Quadro I temos, na primeira linha o genótipo das fêmeas e na segunda o genótipo dos machos (irmãos das fêmeas) que podem ser encontrados dentro de um hospedeiro qualquer.

Os símbolos que colocámos em cada linha, P1, P2, etc., até $\mathrm{Pn}$, não querem dizer precisamente a constituição genética da população, mas representam a constituição genética dos "tipos de cruzamento". Em uma população Pn qualquer obtivemos as seguintes fórmulas gerais para os diversos tipos de cruzamento :

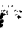

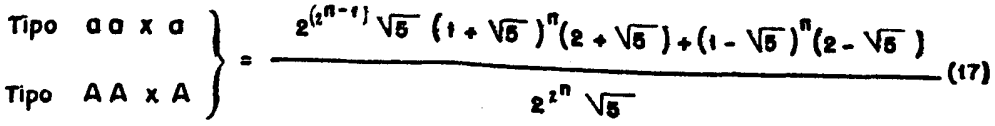

$$
\begin{aligned}
& \left.\begin{array}{l}
\text { Tipo } A A \times(A \text { ou } 0) \\
\text { Tipo a a } \times(A \text { ou } a)
\end{array}\right\}=\frac{(1+\sqrt{5})^{n}-(1-\sqrt{5})^{n}}{2^{2^{n}} \sqrt{5}} \text { (18) } \\
& \left.\begin{array}{l}
\text { Tipo Ao } \times A \\
\text { Tipo Ao } \times 0
\end{array}\right\}=\frac{(1+\sqrt{5})^{n-1}-(1-\sqrt{5})^{n-1}}{2^{2^{n}} \sqrt{5}} \text { (19) } \\
& \text { Tipo Aa } \times(A \text { ou } a)=\frac{(1+\sqrt{5})^{n}-(1-\sqrt{5})^{n}}{2^{2^{n}} \sqrt{5}} \text { (20) }
\end{aligned}
$$


Na última linha do Quadro I colocámos o limite para o qual tenderão nossos grupos de a casalamentos quando o núme. ro de gerações fôr muito grande. Constatámos matematicamente o que a simples indução já nos indicara, isto é, que não havendo seleção teremos ao fim de um grande número de gerações sòmente fêmeas $\mathrm{AA}$ fecundadas por machos $\mathrm{A}$ e fêmeas aa fecundadas por machos a.

Resultados semelhantes a estes que chegamos, porém, corn outras finalidades e por outros métodos, alcançaram, tambẻm Kalmus e Smith. Em sua publicação (1948), Kalmus e Smith analisaram o problema da obtenção de linhas puras em abelhas, sendo que, para isso, consideraram três métodos: a) cruzamento entre mãe e filho; b) cruzamento entre irmão e irmã e c) cruzamento entre tia e sobrinho. Esses estudos tiveram o fim de verificar, por esquemas matemáticos, por quais dos três métodos se obteriam mais ràpidamente, linhagens puras.

Como poderemos vêr, o segundo caso, considerado pelos autores, cruzamento entre irmão e irmã, cai no caso que estudámos agora como existente em populações de himenópteros endogâmiccs; por isso, vamos dar aquí o método e resultados daqueles autores, já que têm relação com o que fizemos.

Kalmus e Smith distinguiram 4 tipos de cruzamentos, cada um dêsses tipos ocorrendo com uma ceria probabilidade na enesima geração, considerando a existência de três aléles $\left(A, A^{\prime}\right.$ e $\left.A^{\prime \prime \prime)}\right)$ :

Cruzamento tipo $\mathrm{P}=\mathrm{AA} \times \mathrm{A}, \mathrm{A}^{\prime} \mathrm{A}^{\prime} \mathrm{x} \mathrm{A}^{\prime}$ e $\mathrm{A}^{\prime \prime} \mathrm{A}^{\prime \prime} \mathrm{x} \mathrm{A}^{\prime}$ ocorrendo com uma probabilidade pn.

Cruzamento tipo $Q=A A \times A^{\prime}, A^{\prime} A^{\prime} \times A$, ou A"A" $\times A$, etc. ... ocorrendo com uma probabilidade qn.

Cruzamento tipo $\mathrm{R}=\mathrm{AA}^{\prime} \times \mathrm{A}, \mathrm{AA}^{\prime} \times \mathrm{A}^{\prime}, \mathrm{AA}^{\prime \prime} \times \mathrm{A}$, 'etc.... ocorrendo com uma probabilidade $\mathrm{rn}$.

Cruzamento tipo $\mathrm{S}=\mathrm{AA}^{\prime} \times \mathrm{A}^{\prime}$ ocorrendo com uma probabilidade $\mathrm{sn}$.

Assim, os autores, aplicando o método de Haldane (1937a) para gens ligados ao sexo, acharam que as probabilidades correspondentes na geração $(n+1)$ são: 


$$
\begin{aligned}
& P_{n+1}=P_{n}+\frac{1}{4} \\
& q_{n+1}=\frac{1}{4} r_{n} \\
& r_{n+1}=q_{n}+\frac{1}{4} r_{n}+\frac{1}{2} s_{n} \\
& s_{n+1}=\frac{1}{2} s_{n}
\end{aligned}
$$

Essas equações foram resolvidas e a fórmula encontrada para pn, que é a probabilidade de haver fêmeas AA fecundadas por machos A, a partir do pior caso, isto é, de um cruzamento tipo S, foi :

$$
P_{n}=1-\frac{(15+7 \sqrt{5})}{20}\left(\frac{1+\sqrt{5}}{4}\right)^{n}-\frac{(15-7 \sqrt{5})}{20}\left(\frac{1-\sqrt{5}}{4}\right)^{n}+2^{-(n+1)}
$$

Apesar das equações apresentadas por Kalmus e Smith satisfazerem o caso das abelhas, achamos que, para o caso das populações de himenópteros endogâmicos terão de ser deduzidas do seguinte esquema, baseado no Quadro I, seguindo o método de Haldane (1) :

Cruzamento tipo $\mathrm{P}=\mathrm{AA} \times \mathrm{A}$ ou aa $\times$ a ocorrendo numa probabilidade pn.

Cruzamento tipo $\mathrm{Q}=\mathrm{AA} \times(\mathrm{A}$ ou a) ou aa $\times \mathrm{A}$ ou a), ocorrendo numa probabilidade qn.

Cruzamento tipo $\mathrm{R}=\mathrm{Aa} \times \mathrm{A}$ ou $\mathrm{Aa} \times \mathrm{x}$ a ocorrendo numa probabilidade $\mathrm{rn}$.

Cruzamento tipo $\mathrm{S}=\mathrm{Aa} \times$ (A ou a) ocorrendo numa probabilidade sn.

(1) Como não pudemos dispôr da publicação de Haldane (1937a.) em tempo, utilizamo-nos, aquí, de outra, que também descreve o método de Haldane e Waddington (1931) e do livro de Hogben (1946). 
Sendo as equações :

$$
\begin{aligned}
& P_{n+1}=P_{n}+\frac{1}{2} q_{n} \\
& q_{n+1}=\frac{1}{2} r_{n}+\frac{1}{2} s_{n} \\
& r_{n+1}=\frac{1}{2} q_{n} \\
& s_{n+1}=\frac{1}{2} r_{n}+\frac{1}{2} s_{n}
\end{aligned}
$$

Essas equações, considerando-se a frequência inicial dos gens como sendo iguais para darem valores simétricos, nos dariam o mesmo resultado obtido pelo método por nós utilizado.

Para obtermos os valores de pn, qn, rn e sn a partir das 4 equações enunciadas, teriamos que proceder da maneira descrita abaixo, conforme nos foi indicado pelo Dr. Frederico Pimentel Gomes, de acôrdo com sua publicação de 1950a. Vamos verificar sómente o valor de qn, ùnicamente para provarque dá o mesmo resultado que o método por nós utilizado;

Verifica-se, em primeiro lugar, que

$$
\begin{gathered}
s_{n}=q_{n} \\
r_{n}=\frac{1}{2} q_{n-1} \\
\therefore p_{n+1}=p_{n}+\frac{1}{2} q_{n} \\
q_{n+1}=\frac{1}{4} q_{n-1}+\frac{1}{2} q_{n} \quad(21) \\
q_{n+1}=\frac{1}{2} q_{n}-\frac{1}{4} q_{n-1}=0
\end{gathered}
$$

Esta equação linear de diferenças, ou também equação recorrente de Haldane, pode ser resolvida por meio do métudo da função geratriz, introduzido por Laplace.

Esse método das funções geratrizes consiste em determi- 
nar o termo geral de uma função desenvolvida em série. Para achar essa função combinam-se 3 funções cujos coeficientes sejam os termos da sucessão em pesquiza.

Admitamos uma função $f(x)$ que, desenvolvida em sêrie, nos dê :

$$
\begin{gathered}
f(x)=q_{1}+q_{2} x+q_{3} x^{2}-\cdots \\
-\frac{1}{2} x \cdot f(x)=-\frac{1}{2} q_{1} x-\frac{1}{2} q_{2} x^{2}-\frac{1}{2} q_{3} x^{3}-\cdots \\
-\frac{1}{4} x^{2} \cdot f(x)=-\frac{1}{4} q_{1} x^{2}-\frac{1}{4} q_{2} x^{3}-\frac{1}{4} q_{3}^{4} x^{4}-\cdots \\
\therefore f(x) \cdot\left[1-\frac{1}{2} x-\frac{1}{4} x^{2}\right]=q_{1}+x\left(q_{2}-\frac{1}{2} q_{1}\right) \\
+x^{2}\left(q_{3}-\frac{1}{2} q_{2}-\frac{1}{4} q_{1}\right) \\
+x^{3}\left(q_{4}-\frac{1}{2} q_{3}-\frac{1}{4} q_{2}\right) \\
+\cdots
\end{gathered}
$$

Os coeficientes de $\mathrm{x}^{2}, \mathrm{x}^{3}, \mathrm{x}^{4} \ldots$ são nulos em virtude da equação (22) cuja solução buscamos.

Logo, tem-se :

$$
\begin{gathered}
{\left[1-\frac{1}{2} x-\frac{1}{4} x^{2}\right] f(x)=q_{1}+x\left(q_{2}-\frac{1}{2} q_{1}\right)} \\
\therefore f(x)=\frac{q_{1}+x\left(q_{2}-\frac{1}{2} q_{1}\right)}{1-\frac{1}{2} x-\frac{1}{4} x^{2}}
\end{gathered}
$$

Substituindo-se os valores de q1 e q2 pelos seus valores iniciais, (veja-se Quadro I, coluna central ou a soma das 2a. e 6a. colunas) :

$$
\begin{aligned}
q_{1}=\frac{2}{4} & q_{2}=\frac{2}{8} \\
f(x) & =\frac{\frac{2}{4}+x\left(\frac{2}{8}-\frac{1}{2} \cdot \frac{2}{4}\right)}{1-\frac{1}{2} x-\frac{1}{4} x^{2}} \\
& =\frac{2}{4-2 x-x^{2}}(24)
\end{aligned}
$$


Resolvendo a equação obtida quando se iguala o denominador a zero, encontram-se as duas raizes, com os seguintes valores :

$$
\begin{aligned}
& \alpha=1+\sqrt{5} \\
& \beta=1-\sqrt{5}
\end{aligned}
$$

Precisamos, agora, desenvolver $\mathrm{f}(\mathrm{x})$ em série para buscar o termo geral. Para tanto fazemos:

$$
\begin{aligned}
& f(x)=\frac{-2}{(x-\alpha)(x-\beta)}=(-2)(x-\alpha)^{-1}(x-\beta)^{-1} \\
& (x-\alpha)^{-1}=(-\alpha)^{-1}+\frac{-1}{1}(-\alpha)^{-2} x+\frac{(-1)(-2)}{1.2}(-\alpha)^{-3} x^{2}+\cdots \\
& =-\frac{1}{a}-\frac{1}{a^{2}} x-\frac{1}{a^{3}} x^{2}-\cdots \\
& -(x-\beta)^{-1} \cdot \frac{1}{\beta}+\frac{1}{\beta^{2}} x+\frac{1}{\beta^{2}} x^{2}+\cdots \\
& \text { Sendo entāo a fungâo eorotriz } \\
& f(x)=2\left[-\frac{1}{\alpha \beta}+x\left(-\frac{1}{a^{2} \beta}-\frac{1}{a \beta^{2}}\right)\right. \\
& +x^{2}\left(-\frac{1}{a^{3} \beta}-\frac{1}{a^{2} \beta^{2}}-\frac{1}{a \beta^{3}}\right) \\
& +x^{n}\left(-\frac{1}{a^{n+1} \beta}-\frac{1}{a^{n} \beta^{2}}+\cdots+\frac{1}{a \beta^{n+1}}\right)
\end{aligned}
$$

$O$ valor qn +1 será igual ao coeficiente do termo geral da série resultante do desenvolvimento em sẹrie da função geratriz :

$$
q_{n+1}=-2\left[\frac{1}{a^{n+1} \beta}+\frac{1}{a^{n} \beta^{2}}+\cdots+\frac{1}{a \beta^{n+1}}\right]
$$

Para condensar êste termo podemos utilizar a fórmula da soma de uma série onde a1 é o primeiro termo, an o último termo considerado, e $\mathrm{r}$ a razão. 


$$
\begin{aligned}
& q_{n+1}=-2\left[\frac{\frac{1}{a^{n+1} \beta}-\frac{1}{a \beta^{n+1}}-\frac{a}{\beta}}{1-\frac{a}{\beta}}\right]=-2\left[\frac{\frac{1}{\alpha^{n+1} \beta}-\frac{1}{\beta^{n+2}}}{1-\frac{a}{\beta}}\right] \\
& =-2\left[\frac{\frac{1}{a^{n+1}}-\frac{1}{\beta^{n+1}}}{\beta-\alpha}\right]=-2\left[\frac{\frac{1}{(-1+\sqrt{5})^{n+1}}-\frac{1}{(-1-\sqrt{5})^{n+1}}}{-1-\sqrt{5}+1-\sqrt{6}}\right] \\
& =2\left[\frac{\frac{1}{(\sqrt{5}-1)^{n-1}}-\frac{1}{(-\sqrt{5}-1)^{n+1}}}{2 \sqrt{5}}\right]=\frac{\frac{1}{(\sqrt{5}-1)^{n+1}}-\frac{1}{(-\sqrt{5}-1)^{n+1}}}{\sqrt{5}} \\
& q_{n}=\frac{\frac{1}{(\sqrt{5}-1)^{n}}-\frac{1}{(-\sqrt{5}-1)^{n}}}{\sqrt{5}}=\frac{\frac{1}{(\sqrt{5}-1)^{n}}-\frac{1}{(-\sqrt{5}-1)^{n}}}{\sqrt{5}} \\
& =\frac{\frac{(-1)^{n}(-1-\sqrt{5})^{n}-(-1)^{n}(-1+\sqrt{5})^{n}}{(-1)^{n}(\sqrt{5}-1)(-\sqrt{5}-1)^{n}}}{\sqrt{5}}=\frac{(1+\sqrt{5})^{n}-(1-\sqrt{5})^{n}}{2^{2 n} \sqrt{5}} \text { (26) }
\end{aligned}
$$

Essa fórmula (26) para qn é igual à que foi dada no Quadro I, na coluna central, como se pode verificar facilmente.

b) Com seleção

Quando há seleção, interessa-nos saber as fórmulas de equilíbrio, sendo que êsse equilíbrio poderá dar-se permanecendo todos os genótipos na população ou com a eliminação completa de um deles.

Para determinar as diversas fórmulas de equilíbrio, raciocinámos da seguinte maneira: se a população está em equilíbrio, então a geração $(n)$ será igual à geração $(n+1)$. Por isso analisemos separadamente os 7 casos possíveis de cruzamentos (seguindo o método de Haldane, 1937a), que já ilustramos no Quadro I :

$$
\text { 1) } \left.\mathrm{AA} \times \mathrm{A}, \text { 2) } \mathrm{AA} \times \frac{1}{2} \mathrm{~A} \text { ou } \frac{1}{2} \mathrm{a}, 3\right) \mathrm{Aa} \times \mathrm{A} \text {, }
$$

4) $\mathrm{Aa} \times \frac{1}{2} \mathrm{~A}$ ou $\frac{1}{2} \mathrm{a}$, 5) $\left.\mathrm{Aa} \mathrm{xa}, 6\right)$ aa $\mathrm{x} \frac{1}{2} \mathrm{~A}$ ou $\frac{1}{2} \mathrm{a}$,

7) aa $x$ a, cada caso acontecendo, respectivamente, com uma probabilidade: pn, qn, rn, sn, tn, un e vn.

Portanto, esquematizando, temos : 


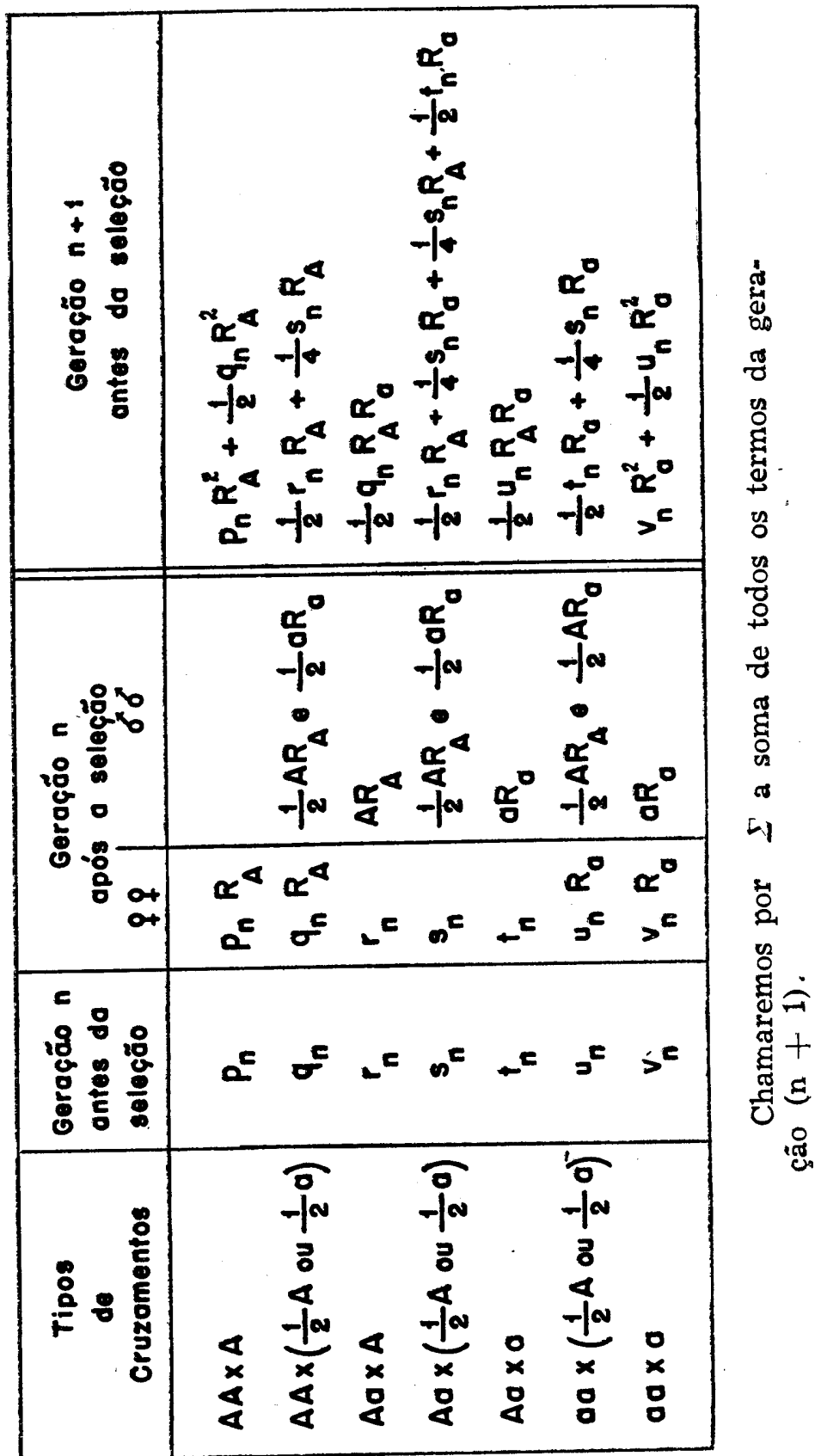


Igualando a geração $(n)$ à geração $(n+1)$, teremos a seguinte série de equações, que, resolvidas, nos darão as fórmulas de equilíbrio para cada caso :

$$
\begin{aligned}
& p=\left(p R_{A}^{2}+\frac{1}{2} q R_{A}^{2}\right): \Sigma \\
& q=\left(\frac{1}{2} r R_{A}+\frac{1}{4} s R_{A}\right): \Sigma \\
& r=\left(\frac{1}{2} q R_{A} R_{a}\right): \Sigma \\
& s=\left(\frac{1}{2} r R_{A}+\frac{1}{4} s R_{0}+\frac{1}{4} s R_{A}+\frac{1}{2}+R_{0}\right): \Sigma \\
& t=\left(\frac{1}{2} u R_{A} R_{0}\right): \Sigma \\
& u=\left(\frac{1}{2} t R_{0}+\frac{1}{4} s R_{0}\right): \Sigma \\
& v=\left(v R_{0}^{2}+\frac{1}{2} u R_{0}^{2}\right): \Sigma
\end{aligned}
$$

A necessidade de dividir por $I \quad$ vem da introdução dos valores de seleção $R A$ e $R a$ que fazem a soma dos termos da geração $(n+1)$ diferente de 1 . Para restabelecer essa igualdade a um, dividimos por $\Sigma$. Deixaremos sòmente indicadas essas equações, pois sua resolução implica numa equação de $5^{\circ}$ gráo, na maioria das vezer muito complexa.

Conseguimos, assim, com o auxílio do Dr. Frederico Pimentel Gomes, chegar a um resultado importante. Suponhamos, para facilidade de cálculo, que $R A$ seja igual a $R a$, e, para não haver confusão de termos, designaremos êsse valor de sobrevivência pela letra $B$.

Podemos extrair o valor de $\Sigma$ da equação (29) :

$$
r \Sigma=\frac{1}{2} q \cdot R_{A} R_{0} \quad \therefore \Sigma=\frac{O B^{2}}{2 r}
$$


Utilizar-nos-emos, agora, sòmente das equações (28), (30), (31) e, (32), substituindo $\Sigma$ pelo seu valor achado em (34), teremos :

$$
\left\{\begin{aligned}
\mathrm{q} & =\left(\frac{1}{2} \mathrm{Br}+\frac{1}{4} \mathrm{Bs}\right) \frac{2 \mathrm{r}}{\mathrm{qB} 2} \\
\mathrm{~s} & =\left(\frac{1}{2} \mathrm{Br}+\frac{1}{4} \mathrm{Bs}+\frac{1}{4} \mathrm{Bs}+\frac{1}{2} \mathrm{Bt}\right) \frac{2 \mathrm{r}}{\mathrm{qB} 2} \\
\mathrm{t} & =\frac{1}{2} \mathrm{~B} 2 \text { u. } \frac{2 \mathrm{r}}{\mathrm{B} 2 \mathrm{q}} \\
\mathrm{u} & =\left(\frac{1}{2} \mathrm{Bt}+\frac{1}{4} \mathrm{Bs}\right) \frac{2 \mathrm{r}}{\mathrm{B} 2 \mathrm{q}}
\end{aligned}\right.
$$

Simplificando, temos :

$$
\left\{\begin{array}{l}
\mathrm{q}=\left(r+\frac{s}{2}\right) \frac{r}{\mathrm{~Bq}} \\
\mathrm{~s}=(\mathrm{r}+\mathrm{s}+\mathrm{t}) \frac{\mathrm{r}}{\mathrm{Bq}} \\
\mathrm{t}=\frac{\mathrm{ru}}{\mathrm{q}} \\
\mathrm{u}=\left(\mathrm{t}+\frac{\mathrm{s}}{2}\right) \frac{\mathrm{r}}{\mathrm{Bq}}
\end{array}\right.
$$$$
\text { Fazendo: } \mathrm{Q}=\frac{\mathrm{q}}{\mathrm{q}}, \mathrm{S}=\frac{\mathrm{s}}{\mathrm{q}} \mathrm{R}=\frac{\mathrm{r}}{\mathrm{q}}, \mathrm{U}=\frac{\mathrm{u}}{\mathrm{q}}
$$

e fazendo-se as substituições nas equações acima, chegamos ao seguinte :

$$
1=\left(R+\frac{S}{2}\right) \frac{R}{B}
$$




$$
\begin{aligned}
& \mathrm{S}=(\mathrm{R}+\mathrm{S}+\mathrm{T}) \frac{\mathrm{R}}{\mathrm{B}} \\
& \mathrm{T}=\mathrm{RU} \\
& \mathrm{U}=\left(\mathrm{T}+\frac{\mathrm{S}}{2}\right) \frac{\mathrm{R}}{\mathrm{B}}
\end{aligned}
$$

Substituindo o valor de $T$ encontrado em (37), nas equäções (36) e (38), temos :

$$
\begin{aligned}
& S=(R+S+R U) \frac{R}{B} \\
& U=\left(R U+\frac{S}{2}\right) \frac{R}{B}
\end{aligned}
$$

Somando (35) com 38), obtemos:

$$
1+U=\frac{R}{B}(R+S+R U)
$$

Porém, verificámos, pela equação (36), que o segundo membro da equação (41) é igual a S.

Portanto :

$$
1+\mathrm{U}=\mathrm{S}
$$

Da equação (35), (39) e (40) extraimos, respectivamente:

$$
\begin{aligned}
& \frac{B}{R}=R+\frac{S}{2} \\
& \frac{B S}{R}=R+S+R U
\end{aligned}
$$




$$
\frac{R U}{R}=R U+\frac{S}{2}
$$

Substituindo S nas equações (43) e (44) pelo seu valor encontrado em (42), temos:

$$
\begin{aligned}
& \frac{B}{R}=R+\frac{1+U}{2} \\
& \frac{R U}{R}=R U+\frac{1+U}{2}
\end{aligned}
$$

que, simplïficadas, dão:

$2 \mathrm{~B}=2 \mathrm{R}^{2}+\mathrm{R}+\mathrm{RU}, \therefore 2 \mathrm{~B}-2 \mathrm{R}^{2}=\mathrm{RU}$

$2 B U=2 R^{2} U+R+R U, \therefore U(2 B-2 R 2)=R+R U$

Dividindo (46) por (47), achamos:

$$
\mathrm{U}=1
$$

Substituindo êsse valor de U na equação (46), temos:

$$
\therefore R=\frac{\begin{array}{c}
2 \mathrm{~B}-2 \mathrm{R}^{2}=\mathrm{R}+\mathrm{R} \\
\therefore \mathrm{R}^{2}+\mathrm{R}-\mathrm{B}=0 \\
-1+\mathrm{V} 1+4 \mathrm{~B}
\end{array}}{2}
$$

A raiz com sinal negativo não nos interessa por dar resultado absurdo biológicamente; portanto:

$$
R=\frac{-1 \mathrm{~V} \overline{1+4 \mathrm{~B}}}{2}
$$

Voltando à equação e substituindo U por 1, temas:

$$
s=2
$$


O valor de Q já é, por hipótese inicial:

$Q=\frac{q}{q}=1$

Como $U$ é igual a um e $T$ é igual a $R U$, temos que $T=R$,

$$
\therefore \mathrm{T}=\frac{-1+\mathrm{V} 1+4 \overline{\mathrm{B}}}{2}
$$

Falta-nos calcular os valores para $\dot{P}$ e V, que, devido ao fato de termos feito por hipótese, $\mathrm{RA}=\mathrm{Ra}$ serão iguais: $\therefore \mathbf{P}=\mathrm{V}$. Recorremos, para acharmos o valor de $\mathrm{P}$, à equação inicial (27):

$\mathrm{p}=\left(\mathrm{pB}^{2}+\frac{1}{2} \mathrm{qB}^{2}\right) \frac{1}{\Sigma}$

Simplificando e substituindo $\Sigma$ por seu valor em (34), temos:

$p=\left(p+\frac{1}{2} q\right) \frac{2 r}{q}$

$p=(2 p+q) \frac{r}{q}$

Portanto, dividindo ambos os membros da equação (53) por q, temos:

$P=(2 P+1) R$

$\therefore \bar{P}=2 \mathrm{PR}+\mathrm{R}$

$\therefore P=\frac{R}{1-2 R}$

Substituindo $\mathrm{R}$ pelo seu valor em (50), temos: 


$$
\begin{aligned}
P & =\frac{-1+\sqrt{1+4 B}}{2} \\
\therefore P & =\frac{1}{2} \cdot \frac{-1+\sqrt{1+4 B}}{2(2-\sqrt{1-4 B})}
\end{aligned}
$$

Encontramos, na equação (55), uma limitação que reputamos importantíssima: para que $\mathrm{P}$ seja positivo (condição para haver equilíbrio sem eliminação dos demais genotipos, é necessário que o denominador seja positivo; logo, surge a seguinte limitação para $\mathrm{B}$ :

$$
\begin{aligned}
v \overline{1+4 B} & <2 \\
1+4 B & <4 \\
\therefore \quad B & <0,75
\end{aligned}
$$

Isto significa que, para existirem gens heteróticos nas populações endogâmicas de Hymenópteros do tipo que estudámos, (porque veremos adiante que poderăo existir outros tipos de populações endogâmicas, que não são encontrados na natureza), de maneira a permanecerem na população todos os genótipos, é nec:ssário que êsses valores de sobrevivência sejam inferiores a $\mathbf{0 , 7 5}$.

Agora que temos as valores de $P, Q, R, S, T, U$ e $V$, podemos, facilmente, obter os valores de $p, q, r, s, t, u \in v$, multiplicando cada um dos primeiros por $q$. $O$ valor de $q$ pode ser obtido da seguinte relação:

$$
\begin{array}{r}
p+q+r+s+1+U+V=1 \\
q=\frac{1}{p+Q+R+S+T+U+V}
\end{array}
$$

Como $P=V, Q=U, R=T$

e substituindo $P$ por seu valor em (55), U por seu valor em (48) $R$ por seu valor em (50) e $S$ por seu valor em (51), temos: 


$$
\begin{aligned}
\therefore q & =\frac{1}{2 P+2 U+2 V+S}= \\
& =\frac{i}{\frac{-1+\sqrt{1+4 B}}{2-\sqrt{1+4 B}}+2+(-1+\sqrt{1+4 B})+2}= \\
& =\frac{1}{4} \frac{3-4 B}{(1-B)(2+\sqrt{1+4 B})} \quad(60)
\end{aligned}
$$

Para darmos um exemplo concreto da apliaação dessas fórmulas, demonstrando a sua perfeita validade, calculámos um caso em que $\mathrm{B} \doteq \mathrm{RA}=\mathrm{Ra}=0,11$.

Esse valor 0,11 foi escolhido por duas razões:

a) por ser inferior a 0,75 e b) porque nos permite extrair

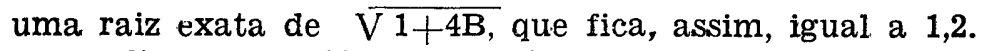

Aplicando as fórmulas e fazendo os cálculos para as frequências dos sete tipos de acasalamentr citados à página 27, quando o equilíbrio for alcançado, obteremos o seguinte:

\section{QUADRO II}

\begin{tabular}{l|l}
\hline Frequência no equilíbrio & Tipo de acasalamento \\
\hline $\mathrm{q}=\frac{1}{4,45} \quad 0,22472$ & AA $\times\left(\frac{1}{2} \mathrm{~A}\right.$ ou $\left.\frac{1}{2} \mathrm{a}\right)$ \\
$\mathrm{p}=\frac{0,125}{4,45}=0,02809$ & AA $\times \mathrm{A}$ \\
$\mathrm{s}=\frac{0,1}{4,45}=0,02247$ & Aa $\times \mathrm{A}$ \\
$\mathrm{t}=\frac{4,45}{0,1}=0,44944$ & Aa $\times\left(\frac{1}{2} \mathrm{~A}\right.$ ou $\left.\frac{1}{2} \mathrm{a}\right)$ \\
$\mathrm{u}=\frac{1}{4,45}=0,02247$ & Aa $\times \mathrm{a}$ \\
$\mathrm{v}=\frac{0,125}{4,45}=0,02809$ & aa $\times\left(\frac{1}{2} \mathrm{~A}\right.$ ou $\left.\frac{1}{2} \mathrm{a}\right)$ \\
\hline
\end{tabular}

Podemos verificar que a soma dos valores encontrados é igual a 1. 
Esses valores encontrados dāo-nos a constituição genética de uma população endogâmica de himenópteras, no equilíbin, com ambos os valores de sobrevivência igual a 0,11.

Essa frequência de equilíbrio é para os tipos de acasalamento; se, no entanto, quizermos a frequência das fêmeas $\mathbf{A A}$ teremas que somar as frequências dos acasalamentos tipos $p$ e q, se quizermos a frequência das fêmeas Aa teremos que somar as frequências dos acasalamentos tipos $r$, $s$ e $t$, e finalmente, se desejarmos a frequência das fêmeas aa precisaremos somar as frequências dos acasalamentos tipos $u$ e v.

E' claro que, para nossas considerações serem válidas, é preciso que existam heterozigutos, pois se somente houver acasalamentos tipos $\mathrm{p}$ ou $\mathrm{v}$, não haverá oportunidade para estabelecer-se o nosso esquema.

Para elucidar melhor êstes pontos fizemos o gráfico 11, em que demonstramos gráficamente a validade das demonstrações e fórmulas expostas nêste capítulo. Nêsse gráfico fizemos $\mathrm{B}=\mathrm{RA}=\mathrm{Ra}=0,11$ (caso calculado acima) e desenhámos a curva seguida pelos diversos tipos de acasalamento por 6 gerações. Para cada tipo de acasalamento calculámos duas curvas, com frequências iniciais diferentes; verifica-se que tanto as curvas pontilhadas como as curvas cheias aproximam-se aos mesmos limites, que são os calculados nos Quadros II.

Após demonstrado um caso em que escolhemos arbitrariamente os valores de sobrevivência, passaremos a fazer algumas considerações de ordem geral. Poderiamos substituir os indices de sobrevivência por valores que correspondam aos diferentes tipos de mutação possiveis, porém, queremos citar apenas os gens heteróticos.

Talvez a principal conclusão que podemos tirar dos estudos dêste capítulo é que há a possibilidade de existirem gens heteróticos em populações endogâmicas de himenópteros.

Para gens heteróticos temos, em geral, a situação seguinte:

a) em plantas ou animais que se reproduzem por autofecundaçāo, para um par de gens heteróticos poder conservar-se na população, é necessário que ambos os indices de sobrevivência sejam inferiores a 0,5 (Brieger 1948).

b) em plantas ou animais diploides, que se reproduzem por fecundação cruzada (panmixia), para os gens poderem ser mantidos na população é necessário que ambos os índices sejam abaixo de 1 .

c) em populações panmíticas de himenópteros as condições para haver gens heteróticos nas populaçōes são: $1^{\circ}$.) ambos os índices de sobrevivência devem ser menores que 1 e. $2^{\circ}$ ) pa- 
ra cada valor de $R a$, o valor máximo que $R A$ poderá alcançar é restringido pela fórmula:

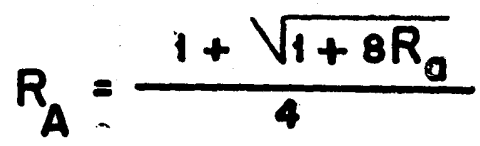

(veja página 238)

d) em populações endogâmicas de himenópteros, para existirem gєns heteróticos passíveis de permanecer em proporções definidas numa população, é necessário que satisfaçam duas condições:

1) Serem, ambos os seus indices de sobrevivência, inferiores a $\mathbf{0 , 7 5}$ (veja fórmula (56)).

Para ilustrar esta conclusão construimos dois gráficos: Gráfico 12 e Gráfico 13. Para o Gráfico 12 escolhemos valores de RA e Ra abaixo de 0,75 e para o Gráfico 13 escolhemos valores para os índices de sobrevivência acima de 0,75. Apesar de os índices de sobrevivência do gráfico 12 diferirem, proporcionalmente, mais entre si $(R A=0,5 \mathrm{Ra}=0,4)$ do que os indices do gráfico 13 ( $\mathrm{RA}=0,9 \mathrm{Ra}=0,8$ ) verificamos que, no gráfico 12, as curvas tendem para um equilíbrio com tôdos os tipos de cruzamento na população, quaisquer que sejam as proporções iniciais entre êsses tipos de cruzamento, ao passo que no gráfico 13 o gen mais viável (A) tende a eliminar o seu alele (a).

A razão dessa eliminação é que, com índices acima de 0,75 , os segregados do tipo $s$ (Aa $\times$ A ou a) são em maior proporção que a contribuição que o tipo $s$ recebe dos demais tipos de acasalamento, e portanto tende a desaparecer. Desaparecendo os híbridos, os gens homozigotos de maior viabilidade rapidamente eliminarão seus aleles devido a que quaisquer pequenas diferenças de viabilídade entre êles serem, agora, aumentadas exponencialmente.

2) Esta segunda condição foi verificada recentemente pelo Dr. Frederico Pimentel Gomes (1950) e pode ser resumida da seguinte maneira: Para haver equilíbrio com todos os tipos de cruzamento na população, para cada valor de $\mathrm{Ra}$, o valor máximo que RA poderá alcançar é restringido pela fórmula: 


$$
\begin{aligned}
4 R_{A}^{5} & +8 R_{0} R_{A}^{4}-4 R_{a} R_{A}^{3}+8 R_{a}^{3}\left(R_{0}-1\right) R_{A}^{2}- \\
& -R_{0}^{2}\left(4 R_{0}^{2}+4 R_{0}-1\right) R_{A}+2 R_{0}^{3}<0
\end{aligned}
$$

Fórmula n.o 3,09 da publicação de Pimentel Gomes, (1950).

Com auxílio dessa fórmula de Pimentel Gomes determinamos, para alguns valores de $\mathrm{Ra}$, qual o valor máximo correspondente que RA poderá ter para que todos os tipos de cruzamentos possam conservar-se na população: São êles :

$$
\begin{array}{ll}
\mathrm{Ra}=0,00 \mathrm{RA}<0,75 & \mathrm{Ra}=0,50 \mathrm{RA}: 0,47 \\
\mathrm{Ra}=0,10 \mathrm{RA}<0,73 & \mathrm{Ra}=0,60 \mathrm{RA}: 0,38 \\
\mathrm{Ra}=0,20 \mathrm{RA}<0,67 & \mathrm{Ra}=0,70 \mathrm{RA}<0,27 \\
\mathrm{Ra}=0,30 \mathrm{RA}: 0,61 & \mathrm{Ra}=0,74 \mathrm{RA}=0,00 \\
\mathrm{Ra}=0,40 \mathrm{RA}<0,54 &
\end{array}
$$

Para demonstrar gráficamente a veracidade dêsses valores limites executamos o Gráfico 14, em que um dos índices cle sobrevivência (Ra) é 0,4 e outro (RA) é 0,7. Apesar de ambas os valores serem inferiores a 0,75 , verificamos, pela tendência dos gráficos, que o tipo de cruzamento AA x A em poucas gerações suplantará os demais.

\section{IV - POPULAÇÕES MISTAS}

Como postulou Bateman (1949), populações verdadiciramente panmíticas, definidas como sendo aquelas nas quais a correlação entre os genotípos de reunirem seus gametas é zero, são necessáriamente muito raras. Portanto, o caso mais comum entre os himenópteros não deve ser o de encontrarmos populações endogâmicas ou panmíticas, mas sim populaçües mistas com preferência a endogamia ou a panmíxia.

Deixaremos, aqui, indicadas as equações que regerão ums população mista.

Além dos acasalamentos considerados no capítulo anterior, teremos que admitir mais dois, $A A \times$ a e aa $\times A$, que no caso de endogamia, não acontece.

Portanto, teremos os seguintes tipos de cruzamentos:

$A A \times A$

$A A \times\left(\frac{1}{2} A+\frac{1}{2} a\right)$

$A A \times 0$
Ao $\times A$

$$
A 0 \times\left(\frac{1}{2} A+\frac{1}{2} a\right)
$$

Ao $\times 0$
$00 \times A$

$$
\cos \left(\frac{1}{2} A+\frac{1}{2} a\right)
$$

$00 \times a$ 
que acontecerão, respectivamente, numa probabilidade pn, qn, rn, sn, tn, un, vn, wn, xn. Admitiremos que haja uma fração $(\alpha)$ de endogamia e uma fração $(\beta)$ de fecundação livre, sendo que:

$$
\alpha+\beta=1 \text {. }
$$

Para calcular a equação do equilibrio dessa população teremos que calcular a porção de endogamia separadamente da porção de cruzamento livre. Para a primeira, procedemos como no capítulo anterior, isto é: os tipos de cruzamento entre dois homozigotos, pn e $x n$, contribuem sòmente para $p(n+1)$ e $x(n+1)$; o tipo qn contribue para $p(n+1)$ com $\frac{1}{2}$ qn e para $\mathrm{s}(\mathrm{n}+1)$ com $\frac{1}{2} \mathrm{qn}$, e assim por diante segundo o esquema que faremos abaixo, sendo cada termo multiplicado pelo fator de endogamia (a).

Para calcular a porção com cruzamento livre fizemos a seguinte suposição: ainda dentro do hospedeiro (se for, por exemplo o caso de alguns himenópteros parasitas) ou na vizinhança de uma mesma colónia (como no caso de algumas formigas), teremos que considerar os machos de acôrdo com a segregação gônica da fêmea mãe, e, porisso, teremos três casos:

$$
1 \quad 1
$$

(A), (a) e (-A ou -a), porém, após sair do hospedeiro ou,

no outro caso da vizinhança do próprio formigueiro, ou se houver enxames sincrônicos, só precisaremos considerar a frequência com que ocorrem os machos $\mathrm{A}$ e a.

A frequência dos machos $\mathrm{A}$, ou a e de fêmeas $\mathrm{AA}, \mathrm{Aa}$ e aa será :

$$
\begin{aligned}
\delta \delta A=y= & p_{n}+q_{n}+r_{n}+\frac{1}{2}\left(s_{n}+t_{n}+u_{n}\right) \\
\delta \delta a=z= & v_{n}+w_{n}+x_{n}+\frac{1}{2}\left(s_{n}+t_{n}+u_{n}\right) \\
& \text { Iq } A A=p_{n}+q_{n}+r_{n} \\
& \text { I } A a=s_{n}+t_{n}+u_{n} \\
& \text { iq Oa }=v_{n}+w_{n}+x_{n}
\end{aligned}
$$


Portanto, basta-nos combinar as frequências dos machos com as fêmeas, multiplicando seus termos por b (fração de cruzamento livre) que obteremos a porção da população que se reproduz por panmixia.

Teremos, portantó, a seguinte série de equações que regerão uma população mista de himenópteros:

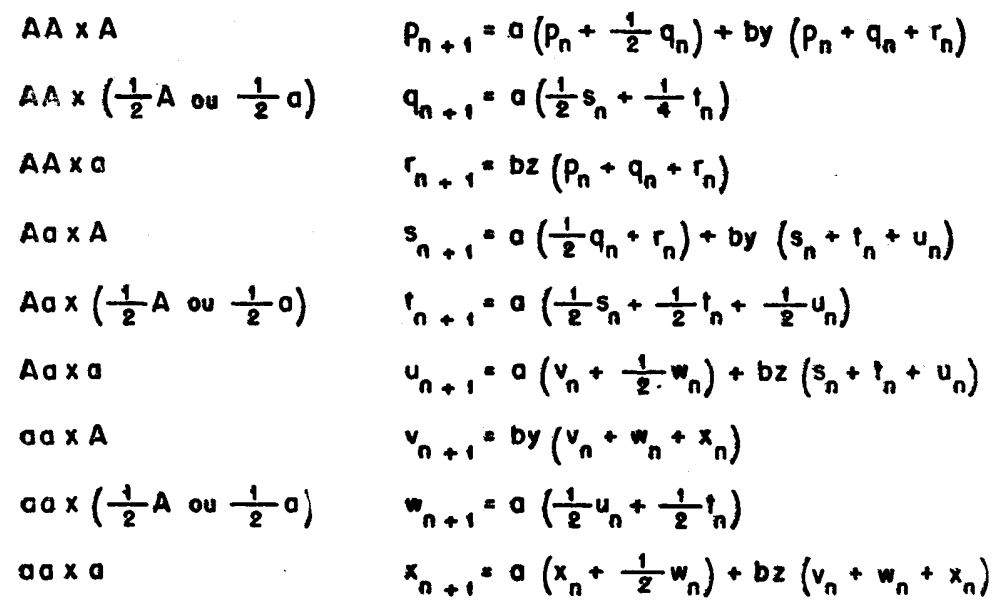

Nāo resolveremos estas equações, por desconhecermos os métodos para a sua resolução; porém, achamos de certa importância podermos relatar quais as bases teóricas de uma população mista de himenópteros, pois julgamos ser desta classe a maioria dos casos que temos encontrado.

\section{V - MUDANÇAS NO MECANISMO DE REPRODUÇÃO}

No caso de himenópteros com fecundação cruzada tornouse possível em algumas espécies. a mudança no mecanismo de cruzamento por meio da técnica de inseminação artificial com a microseringa. Esse método foi desenvolvido por Watson (1927 a e b) e últimamente aperfeiçoado por Nolan (1937), Roberts (1947), Mackensen (1948) e Laidlaw (1949). 
Com êsse processo Mackensen conseguiu até mesmo autofecundar uma rainha de Apis mellifera L., seguindo os seguintes passos (Farrar 1947, 1948, Hambleton, 1947): Adormece-se a rainha virgem com $\mathrm{CO}^{2}$, o que a excita a iniciar a postura poucos dias após, mesmo sem fecundação (Mackensen 1947). Os filhos dessa rainha serão tôdos machos, devido à razão de a mesma não ser fecundada. Um dêsses machos, então, é utilizado para ceder o semen, que irá fecundar sua própria mãe. Como êsse macho é originado de uma oosfera não fertilizada, os seus espermatozoides serão todos dêsse mesmo tipo. Assim, se repetirmos êsse processo em uma população que vinha mantendo seu equilíbrio, segundo o que estudámos para as populações panmíticas, esta passará, agora, a seguir o mesmo esquema dos organismos autofecundados. E' claro que, para a seleção artificial, êsse processo ainda é melhor que a autofecundação, porque, como é o operador que escolhe os machos, a situação é idêntica a um melhorista que pudesse autofecundar uma planta com grãos de pólen de um só genótipo previamente escolhido.

Esse assunto, o da mudança do mecanismo reprodutivo, foi fartamente estudado por Brieger em populações diploides, em sua publicação já citada (1948). Para o caso especial de Apis mellifera L. foi estudado, se bem que à parte do estudo da genética de populações, por Kalmus e Smith na sua publicação já citada (1948), e são analizados três casos básicos possíveis de mudança do sistema reprodutivo que, como já dissemos, é o de panmixia (1). Daremos, aquí, os 3 casos estudados pelos autores, com as observações que julgamos mais interessantes.

\section{1.o) Cruzamento entre mãe e filho}

E' o que já citámos, à guisa de exemplo, e que consiste em excitar uma rainha virgem (fo) à postura e utilizar um dos seus filhos (mo) para fecundá-la, obtendo-se, assim, uma fêmea (f1), continuando-se o processo.

Kalmus e Smith. esquematizaram êste caso, segundo a figura 1.

Cada passo da geração $(n)$ para a geração $(n+1)$ é chamada pelos autores como "geração dupla". 
Desconsiderando mutações ou letais ligados a um determinado par de caracteres, os autores verificaram que, desde que homozigotos produzem só homozigotos, a probabilidade de uma rainha ser heterozigota é reduzida pela metade em cada geração, e, portanto, após (n) "gerações duplas", será igual a 2-n (portanto, igual a $0,5 \mathrm{n}$ ), e de ser homczigota será

$(1-2-n)$. Se ao invés de um par de aléles forem considerados (m) pares de gens não ligados em diferentes cromosomas então após (n) "gerações duplas", a chance de (m) pares serem homozigotos será $(1-2-n) \mathrm{m}$.

\section{2.o) Cruzamento entre irmã e irmão}

Este caso corresponde ao que estudámos sob o título de "populações endogâmicas", ao qual já fizemos fartas referências. Foi esquematizado por Kalmus e Smith segundo a fig. 2. Para valores moderadamente elevados de números de gerações (n) o valor de pn, que citámos no capítulo sôbre populações endogâmicas, transforma-se, segundo Kalmus e Smith, em $\mathrm{pn}=1-1,533(0,8090) \mathrm{n}$.

\section{3.o) Cruzamento entre tia e sobrinho}

Este sistema, que segue o esquema da fig. 3, pode ser sumarizado como segue : um macho $(\mathrm{mo})$ é cruzado com uma fêmea (fo) e obtemos duas fêmeas f1 e f'1. De f'1 obtemos o macho $\mathrm{m} 1$, que será cruzado com $\mathrm{fl}$, sendo êsse processo repetido daí por diante. Cada passo dêsses é, também, chamado por Kalmus e Smith de "geração dupla". Neste sistema, o valor de pn, isto é a probabilidade de encontrar na enésima geração cruzamentos do tipo AA x A ou A'A' x A' ou A"A" x A", é, segundo Kalmus e Smith, para valores de $\mathrm{n}$ moderadamente. grandes : $\mathrm{pn}=1-1,616(0,6830) \mathrm{n}$.

Comparando êstes três sistemas de cruzamento, Kalmus a Smith chegaram às seguintes conclusões, muito interessantes principalmente para os melhoristas de abelhas:

No sistema de cruzamento "mãe com filho" a impureza é reduzida por um fator $0,5 \mathrm{n}$ onde $\mathrm{n}$ é o número de "gerações

(1) — Após termos defendido esta tése, tivemos em nossas mãos a publicação de Polhemus, Lush e Rothenbuhler (1950), que descreve, além dos 3 tipos de endocruzamento citados aqui, mais os seguintes :

c) sobrinha $\mathrm{x}$ tio

d) Sucessivas rainhas com machos de uma rainha (ou seja irmã $x$ irmão, sobrinha $x$ tio, sobrinha neta $x$ tio avô, etc.).

f) primos de 1.0 gráu. 
duplas"; igualmente, no cruzamento de "tia com sobrinho" é reduzida por um fator $0,6830 \mathrm{n}$., e em $\mathrm{n}$ "gerações simples" nos cruzamentos entre "irmão e irmã a" é reduzida por um fator $0,8090 \mathrm{n}$.

Desde que :

$$
0,56=0,016, \quad 0,683011=0,015, \quad 0,809020=0,015
$$

Kalmus e Smith concluem que 6 gerações duplas, nos cruzamentos "mãe x filho", são tão efetivos como 11 gerações duplas nos cruzamentos tipo "tia $x$ sobrinho" e 20 gerações simples nos cruzamentos tipa "irmã x irmão".

Digamos de passagem, que, dos tipos de endocruzamentos descritos por Kalmus e Smith, só temos notícia da existência, na natureza do tipo "irmã x irmão" e por isso nos detivemos em estudá-lo com mais detalhe.

\section{2.a Parte}

\section{INFORMAÇOES BIOLOGICAS SOBRE OS APINAE SOCIAIS, ESPECIALMENTE OS MELIPONINI, NECESSARIOS AO ESTU- do Particular da Genetica de POPUlaçóes}

Em sua publicação "Mecanismo da Evolução e origem das espécies" (1944) Dobzhansky esboça 7 tipos de informações necessárias para o julgamento das potencialidades evolutivas de um ser vivo ou grupo de organismos:

1) Mecanismo de reprodução 2) Hábitos de reprodução 3) Tipo de distribuição 4) Densidade de população 5) Meios de distribuição 6) Taxas de mutação 7) Estrutura e eomportamento do mecanismo cromosômico.

Em carta a nós dirigida, o prof. Dobzhansky acha que a êsses pontos se poderia acrescentar mais um, também muito importante, que é o "coeficiente de endocruzamento". Deixaremos, entretanto de tratar nesta tese dêsse coeficiente, por nos faltarem dados tanto para calculá-lo como para demonstrar sua atuação entre os Hymenoptera sociais. Pela mesma razão deixaremos de falar sôbre a "taxa de infiltração" que é também, um fator importante.

Tôdas estas informações são também úteis ao estudo da genética de populações, mesmo porque podemos considerar o 
estudo da evolução como um dos capítulos mais excitantes da genética de populações; por essa razão estudaremos êsses tópicos, de acôrdo com os conhecimentos atuais sôbre os Apinae sociais, nêste primeiro capítulo desta parte.

\section{I - DETERMINANTES DAS POTENCIALIDADES EVOLUTIVAS}

Antes de entrar, diretamente, no estudo dos diversos determinantes das potencialidades evolutivas queremos definir o que entendemos por "potencialidade evolutiva". Chamamos de "potencialidade evolutiva" à capacidade potencial de uma espécie poder modificar sua frequência gênica e a sua frequência de cobinações gênica.

Seguindo o esquema de Dobzhansky, passaremos a relatar diversas informações importantes ao estudo da genética de populações dos himenópteros sociais.

\section{a) Mecanismo e hábitos de reprodução}

Como dissemos, ao distinguir os tipos de reprodução, no início da primeira parte deste estudo, os himenópteros sociais reproduzem-se, preferencialmente, por fecundação livre.

Nos Bombini, que constituem a tribu mais primitiva dos Apinae, há diversos trabalhos sôbre seus processos de reprodução, porém 'só tivemos a oportunidade de conhecer o de Fairchild e Barrett, o de Frison (1927) e o de Sladen (19). Os primeiros observaram, no outono (13 de Outubro), uma fêmea e um macho de Bombus fervidus F. em cópula, parados sôbre um tronco de cereja, a 6 polegadas do chão. Frison (1927) conseguiu a fertilização de fêmeas dentro de vasilhames de vidro, tendo sido bem sucedido nas seguintes espécies: Bombus americanorum FAB., B. bimaculatus CRESSON e $B$. vagans CRESSON. Sladen. (pg. 14) sugere-nos que algumas espécics de Bombus (especialmente B. ruderatus) copulem no ar.

Sôbre a duração das colonias, os Bombini diferem fundamentalmente dos Apini e Meliponini, pois enquanto os Bombini possuem colonias anuais formando-as no início da primavera e dissolvendo-as no fim do outono, as outras duas tribus possuem-nas permanentes.

Tanto nos Apini como nos Meliponini, o processo de reprodução está intimamente ligado à formação de uma nova col- 
méia, porém o processo utilizado por ambas as tribus é bastante divergente, como podemos verificar pelo resumo que faremos :

APINI - Descreveremos, aquí, resumidamente, a formação de novas colméias, como se dá na natureza, para a espécie Apis mellifera L., que é sem dúvida a mais estudada.

Por motivos diversos, por exemplo exiguidade de espaço, excesso de população, estação do ano, as operárias iniciam a construção de diversas células para machos.com o objetivo de produzir zangões para próximos enxames. Daí a poucos dias inicia-se a construção de células reais em cada uma das quais a rainha põe um ovô. Cada larva de rainha é alimentada com a "papa real" (alimentação glandular especial) desde seu nascimento até o fim da vida, ao contrário dos machos e operárias, que após o 3.o dia da fase larval passam a receber em sua alimentação pólen e mel. Uns 8 a 9 dias após as células reais mais adiantadas terem sido operculadas, se o tempo estiver bom, entre 10 e 14 horas (Root, 1943, pag. 228) a rainha velha acompanhada de uma boa quantidade de abelhas adultas enxameia e abandona a colméia primitiva, em busca de outra casa. Ésse enxame é chamado, pelos apicultores, como enxame primário. $\mathrm{Na}$ colméia velha nasce uma das rainhas prestes a emergir, e que, depois de fecundada, pode sair em um novo enxame que é chamado secundário. As operárias, rainhas e também alguns machos que saem no enxame, quer seja primário, quer secundário, (que pode sair da colméia mãe mais ou menos uma semana após a saída do primário, Root (1943) estacionam em qualquer sítio, tal seja um galho de árvore, para descansar, (de 15 minutos até mais de um dia). Daí as operárias voam a procura de nova morada. E' sabido que, em alguns casos, o enxame abandona a colméia máe e segue diretamente para uma cai$\mathrm{xa}$, ôco de árvore ou outro sítio apropriado, instalando-se imediatamente, dando indicação de que as operárias já visitaram e elegeram o local antecipadamente (Allan Lathan, Apud Root, 1943).

A fecundação de uma rainha virgem é uma operação independente da enxameação: desde que haja falta da rainha fecundada em uma colméia, quer por decrepitude ou morte, quer por sua saída em um enxame, uma nova rainha será fecundada. Para a sua fecundação, a rainha virgem, 5 a 12 dias após sua emersão, sai da colméia, para o "vôo nupcial" (pois ela sai, também, para vôos de reconhecimento) acompanhada de um grande número de machos. Dêsses machos, um consegue vencer a competição e acasalar-se com a rainha, passando 
para esta todo o seu conteúdo de semen e do mucus secretado pelas glândulas accessórias. Esse mucus seca-se e vai servir como um tampão impedindo a saída imediata dos espermatozoides. O macho morre, logo em seguida ao vôo nupcial, devido ao fato de ser parte de seus orgãos genitais arrancada no final da cópula. O vôo nupcial dura, desde 5 até 31 minutos (Robert, 1944), iniciando a rainha sua postura 3 a 4 dias após a realização da cópula (Root 1943).

Acreditava-se que as rainhas sofressem, sempre, uma só fecundação, porém trabalhos recentes de Roberts (1944) e Shoemaker (1947) mostraram que tal não se dá, havendo com alta frequência o acasalamento múltiplo.

$\mathrm{Na}$ ocasião do vôo nupcial são admitidos, tanto na colméia como no enxame de machos que procurarão acasalar-se com a rainha, não só os machos da própria colméia, portanto irmãos da rainha, como também machos de outras colméias, que poderão ser da mesma subespécie como de subespécies diferentes. E' por isso que Watson (1928) escreve: "Todas essas variedades (1) intercruzam-se assim que lhes é dada a oportunidade, parecendo certo que as barreiras geográficas tais como águas, montanhas e desertos, tornaram possível, primeiro, a evolução dessas variedades e depois, sua preservação através dos séculos". Podemos dizer que, a não ser em casos de colméias isoladas, sem outras nas proximidades dentro de um ráio de $10 \mathrm{kms}$., a porcentagem de fecundação livre deverá ser relativamente maior que a de endocruzamento.

MELIPONINI - Até há pouco tempo, o mecanismo da enxameagem entre as Meliponini era pràticamente desconhecido. Porém, agora, temos mais luzes sôbre êsse problema em face das observações feitas recentemente por Nogueira Neto (1948). Daremos, aqui, resumidamente, o que foi observado por êsse autor, frisando, quando fôr o caso, nossas observações sôbre êsse assunto.

Sintetizando, em forma, tanto quanto possível cronológica, temos o seguinte esquema para os diferentes passos executados pelos elementos de uma colónia mãe para a fundação de uma nova colónia.

(1) Dentro da espécie Apis mellifera L. há diversas subespécies às vezes acreditadas erradamente, pelos apicultores, como boas espécies. As variedades consideradas pelo autor citado são carniolanas, italianas, cipreanas e caucasianas. 
a) Atividades de reconhecimento e escolha da nova moradia. - Quando a colónia está apta para enxamear, verifica-se em determinados pontos, onde haja ôcos em uma parede, em uma pedra, em um tronco de páu, etc., que há um certo número de abelhas voejando à procura de um local onde possam estabelecer a nova moradia. As abelhas parecem preferir sítios já visitados no ano anterior ou lugares em que jả houve uma colónia, talvez devido ao aproveitamento da cêra. As primeiras observações sôbre êsse assunto foram feitas por Nogueira Neto (pp. c.) em 5 sub-gêneros de Trigona.

Verificámos que há preferência por um lugar já visitado no ano anterior, observando-se nos meses de Setembro a Novembro a visita a um mesmo sítio por operárias de T. (Plebeia) mosquito F. SMITH, em 4 anos $(1944,1945,1946,1949)$. Quanto à escolha prévia do local, verificámos em T. (Friesella) schrottkyi FRIESE em Julho e Agosto de 1949. um detathe interessante, aparentemente na primeira semana da "escolha". Diversas operárias optaram por diversas fendas do soalho de uma casa em Rasgão (E. S. Paulo). Dois dias depois uma grande parte das fendas foram abandonadas, ficando sòmente três. Após mais uma semana haviam optado por duas. sòmente, eliminando as demais. Este foi o único caso de enxame duplo que observámos até agora.

b) Fechamento das frestas - Assim que as operárias escolham um determinado local para abrigar a nova colónia iniciam uma operação de calafetamento de tôdas as frestas e a construção do oríficio de saída (Nogueira Neto, o. c.). Verificámos em T. (F.) schrottkyi FRIESE que, mesmo quando ainda havia diversos locais em experimentação, as operárias de cada um dêles iniciaram o proceso de lacramento das frestas.

c) Transporte de cera, mel e pólen da colméia mãe para o novo local.

Este é um dos passos mais importantes, que separa rígidamente o tipo de enxameação dos Meliponini do existente entre os Apini. Após a calafetagem da nova colméia, as operárias agora em número crescente iniciam o transporte de cera da colméia mãe para a nova. Tal fato foi observado pela primeira vez e experimentalmente demonstrado por Nogueira Neto (o. c.) em Trigona (Tetragonisca) jaty F. SHITH, T. (Plebeia) mosquito F. SMITH T. (Friesella) schrottkyi FRIESE, T. (Nannotrigona) testaceicornis LEP., T. (Trigona) hyalinata LEP.. Tivemos ocasião de observar êsse fato pessoalmente em T. (Plebeia) mosquito F. SMITH, Trigona (Tetragonisca) jaty F. SMITH, Trigona (Friesella) schrottkyi FRIESE e $M$. 
fuscatamelanoventer (SCHWARZ), sendo, provavelmente, patrimônio comum dos Meliponini.

Outro detalhe sugerido por Nogueira Neto foi por nós observado em Trigona (Tetragonisca) jaty F. SMITH e em $M$. fuscata melanoventer (SCHWARZ). Trata-se do transporte de mel e de pólen. Em T. (Tetragonisca) jaty F. SMITH verificámos que as operárias entravam sem pólen nas patas e no entanto alguns potes começaram a encher-se dêsse material. Cêdo verificámos que o pólen era trazido no "papo" das operárias, razão pela qual o pólen da colónia incipiente ao invés de ser granulado era pastoso; como êsse processo é o utilizado para "saque" pelas Lestrimelittas e como não é o método normal de transporte de pólen, deduzimos que êsse material era retirados pelas operárias na colónia mãe. Nogueira Neto verificou o transporte de pólen nas patas trazeiras, em Trigora (Trigona) hyalinata LEP., porém, não há certeza de que seja da colónia mãe ou coletado diretamente das flores, sendo esta última hipótese a mais provável. Constatámos na colónia de Melipona fuscata melanoventer (SCHWARZ) ainda sem rainha, a existência de "invólucro" e de potes de pólen e mel. Vemos assim que se estabelece uma verdadeira colônia parasita, até estar suficientemente equipada para manter-se. Como pondera Nogueira Neto (op. cit.) êsse hábito é muito mais seguro para garantir o sucesso da enxameagem que o utilizado pela Apis mellifera L.

d) Enxame de machos - Depois do que acima foi exposto, os machos da colónia mãe e de outras colméias vizinhas começam a chegar em número cada vez maior pelo espaço de 4 a 5 dias aproximadamente, estacionando em galhos, troncos ou objetos próximos à nova colméia ou dentro da mesma; uma grande parte dêles fica voejando ao redor da colméia, possívelmente à espera do vôo nupcial da nova rainha.

Esse enxame de machos já foi observado em diferentes espécies por diversas pessoas:

Alfonso Dampf observou em 18 de Setembro de 1932 às 4 horas da tarde um enxame de machos de Trigona, subgênero Scaptotrigona, porém na amostra que coletou foi verificado existirem 32 espécimens da espécie luteipennis FRIESE e 2 espécimes da espécie pectoralis, DALLA TORRE (Schwarz 1948, pg. 57), fato interessantíssimo, demonstrando que os enxames de machos não só são de colónias diferentes, (como verificámos em Melipona quadrifasciata LEP.) mas, também, de espécies diferentes. Estas observações de Dampf e Schwarz levaram-nos a compará-las às de George Streisinger (1948) com 
machos de Drosophila melanogaster MEIGEN e D. pseudoobscura FROLOVA e fêmeas de $D$. pseudoobscura FROLOVA, $D$. melanogaster MEIGEN e D. persimilis DOBZHANSKY e EPLING, eterizadas ou não, demonstrando que os machos têm uma tendência, embora mais acentuada em umas espécies que em outras, de aceitarem fêmeas de espécies diferentes, verificada pelo fato de os machos copularem com fêmeas heteroespecíficas quando eterizadas, porém, quando as fêmeas não estão eterizadas, não permitem ou permitem raramente a cópula heteroespecífica.

Bequaert observou muitos machos de Trigona (Cephaiotrigona) capitata variedade zexmeniae COCKRELL em galhos e fôlhas próximos à colméia '(ap. Schwarz, 1948, pg. 57).

Michener (1946) observou diversos enxames de machos: em Trigona (Tetragonisca) jaty F. SMITH, Trigona (Trigona) fulviventris variedade fulviventris GUERIN, Trigona (Scaura) latitarsis FRIESE, Trigona (Nannotrigona) testaceicornis variedades perilampoides CRESSON, Melipona favosa variedade phenax COCKRELL e Trigona (Partamona) testacen KLUG. Pode ser que uma grande parte dêstes enxames observados não esteja ligada à formação de uma nova colónia, mas sim que seus componentes sejam apenas machos expulsos da colónia mãe, ou, então, enxames de machos para fecundação de uma nova rainha por falta da rainha fecundada. Achamos que a expulsão de um grande número de machos de diversas colméias que não têm necessidade dêles, na época da enxameagem, obrigando-os a procurar os lugares̀ onde há colónias incipientes ou colónias com falta de rainhas fecundadas, constitui um dos principais fatores responsáveis pela porcentagem de fecundação livre nos Meliponini. Fatos dessa natureza observámos em Trigona (Scaptotrigona) pectoralis DALLA TORRE, onde não era permitido aòs machos, em número superior a 1.000 , entrarem na colónia durante o dia; paulatinamente foram se dispersando até que, ao fim de 15 dias, não eram mais encontrados nas proximidades da colónia-mãe.

Enxames de machos diretamente relacionados com a fundação de uma nova colonia, ao que parece, até agora só foram observados, primeiramente, por Paulo Nogueira Neto em T'rigona (Tetragonisca) jaty F. SMITH, T. (Plebeia) mosquito F. SMITH T. (Friesella) schrottkyi FRIESE, T. (Nannotrigona) testaceicornis LEP., e T. (Trigona) hyalinata LEP., e por nós, em Trigona (Tetragonisca) jaty F. SMITH, T. (Plebeia) mosquito F. SMITH, T. (Friesella) schrottkyi, FRIESE, Melipona fuscata melanoventer. 
e) Instalação da rainha virgem - Suprida a nova colméia de cêra, mel e pólen, tendo um número suficiente de operárias, e após haver, já, um bom número de machos, que, ás vezes, atinge proporções enormes, uma rainha virgem (não a fecundada como no caso de Apis mellifera L.) transporta-se para a nova colónia. Segundo Nogueira Neto (op. cit.), ela talvez tome posse primeiro da colméia, para depois ser fecundada. A ida da nova rainha, em alguns casos, parece ser acompanhada de grande número de operárias, como foi verificado por $\mathrm{Pe}$ ckolt (Apud Schwarz, 1948, pag. 60) em Cantagalo com Trigona (Trigona) ruficrus LATREILLE; essa observação é, no entanto, posta em dúvida quanto à sua interpretação, por diversos pesquisadores.

f) Fecundação da fêmea fértil - Éste detalhe do mecanismo de reprodução dos Meliponini foi, até agora, sòmente observado por Kerr e Krause (1950) em Melipona quadrifasciata quadrifasciata LEP. Nessa observação de Kerr e Krause foi constatada que, após a colónia ter ficado orfã, as operárias continuam a matança das virgens até se aperceberem que não possuem rainha fecundada: na experiência realizada as operárias mataram virgens até quase dois dias após a rainha ter sido retirada. No sexto dia de observação uma rainha virgem saiu da colméia, executou un vôo nupcial que durou 4 minutos e meio e ao tentar entrar novamente na colónia foi capturada e dissecada tendo os autores verificado que tôda a genitália do macho, incluindo o penıs e as vesículas seminais estavam presos dentro de sua vágina. Êsse é um passo em que os Meliponini diferem da Apis mellifera L., pois nesta a única parte do macho que é arrancada é o penis, e a obstrução da vagina é feita pela secreção das glândulas accessórias do macho, que ao secar serve de tampão para evitar a saída dos espermatozoides, para o exterior. Nos Melipinini essa operação é executada pela genitalia, penis e vesículas seminais que ficam comprimidos pelos últimos segmentos abdominais da fêmea.

Entretanto, não há diferenças fundamentais entre o processo de fecundação da fêmea fértil entre os Apini e Meliponini.

g) Início da postura - $\mathrm{O}$ início da postura da fêmea após a fecundação é variável, de acôrdo com o alimento existente na colméia e com o número de operárias. Ássim, verificámos em duas colónias novas que observámos, de Trigona (Tetrago- 
nisca) jaty F. SMITH, que as rainhas iniciaram a sua postura aproximadamente 5 e 6 dias, após constatada sua presença na colméia. Por perda da rainha fecundada verificámos, em diversas colónias já estabelecidas, duração de tempo variável para o início da postura. Provavelmente, a duração de tempo para iniício da postura, após os enxames será idêntica; por isso damos aquí alguns exemplos :

Melipona quadrifasciata LEPELETIER: desde 6 até 20 dias. Melipona scutelaris scutelaris LATREILLE : 6 dias.

Melipona rufiventris rufiventris LEPELETIER: 16 dias.

Melipona schencki GRIBODO : 30 dias.

Melipona favosa orbignyi GUERIN : 10 dias.

Observámos, em Trigona (Tetragonisca) jaty F. SMITH numa das colónias recenfundadas já citadas, que a rainha iniciou sua postura em células colocadas em planos diferentes, unidas entre si por pequenas pilasiras de cêra, dando uma idéia do conjunto de alvéolos que se verifica nas colónias das espécies do tipo Trigona (Tetragona) silvestrii FRIFS I. Só após alguns dias é que, com o aumento da postura, as operárias iniciaram paulatinamente a construção em forma de favos organizados, quer seja em camadas, quer helicoidalmente. Isso porém, não é geral, pois na outra colméia de Trigona (Tetragonisca) jaty F. SMITH ciłada, as operárias desde o início construiram seus alvéolos em camadas. O tempo de duração de tôdas estas operações de enxameagem é muito variável de caso para caso. O enxame mais rápido que observámos foi o que saíu de nossa colméia n. 94 (T. (T.) jaty F. SMITH) para a n. 100, que se iniciou em 1.0 de Janeiro de 1950 e. 18 dias mais tarde a rainha pôs o 1.0 ôvo.

Temos assim tratado do mecanismo de reprodução, que é um ponto de grande importância para o. estudo da genética de populações de três gêneros de himenópteros sociais (Apis, Melipona, e Trigona).

O sexo feminino (cperárias e rainhas) é o mais frequệnte nos himenópteros sociais, porém se considerarmos sòmente os indivíduos férteis, isto é os machos e rainhas, verificaremos que a classe masculina é muito mais representada, mesmo no gênero Melipona, onde há produção de maior número de rainhas. Porém na grande maioria dos casos, uma rainha é 
fecundada uma única vez e por um só macho (1), o que torna o número de machos e fêmeas genéticamente ativos iguais; dessa forma, cremos que a competição entre os machos deve ser muito grande.

Como usámos, aqui, o termo "genèticamente ativos", queremos deixar definido que consideramos "indivíduos genéticamente ativos" os indivíduos que deixam descendentes, pois os milhares de machos e centenas de rainhas produzidos não têm interesse para a genética de populações, a não ser a rainha que formará a nova colónia e o macho que a fecundou.

A duração da vida de um macho, após sua maturidade sexual, é aproximadamente de 5 a 10 semanas para Apis, Melipona e Trigona, e para a rainha podemos ter como base no mínimo 2 anos; (esta é a idade em que os apicultores costumam substituir suas rainhas, porém, normalmente, a rainha dura até 4 a 5 anos). E' claro que essa situação diminui a população genèticamente ativa, pois, nesse período de aproximadamente 2 a 3 anos, a rainha age com a carga hereditária de um só macho; sem dúvida, haveria uma população genèticamente ativa maior, se nesse mesmo tempo a rainha fosse fecundada por um grande número de machos.

b) Tipos de distribuição.

Aqui não podemos fazer generalizações para quaisquer dos grupos dos himenópteros sociais, como fizemos com o mecanismo e hábitos de reprodução para os Apini e Meliponini, pois quanto ao tipo de distribuição, estamos na absoluta dependência da espécie, principalmente por entrarem em jôgo fatores ecológicos e geográficos.

Do ponto de vista da distribuição geográfica estudámos com detalhe uma espécie, a $M$. quadrifasciata LEP. e construimos o mapa da figura (7) com os dados que conseguimos, quer pessoalmente, quer estudando insetos encontrados nas coleções dos museus e de particulares, ou por insetos recebidos por inte:médio de amigos, já citados no início dêste trabalho. Outras espécies do complexo fasciata, foram também estudadas geográficanıente no trabalłio de Moure e Kerr (1950).

(1) Como já citámos, uma rainha pode ser fecundada por dois ou mais machos (Robert 1944); o contrário, porém isto é, um macho fecundar duas ou mais fêmeas, nunca se dá naturalmente; com auxíío da microseringa pode se conseguir uma inseminação de mais de uma fêmea com semen de um só macho; Watson (1927b) \& outros (Nolan 1937) conseguiram inseminar rainhas virgens de Apis mellifera L. com semen de seus próprios pais, utilizando-se do esperma depositado na espermateca das rainhas mães. 
Pelos estudos que já fizemos, verificámos que há algumas espécies, adaptadas à mais variadas condições ecológicas como a Trigona (Tetragonisca) jaty F. SMITH, Trigona (Nannotrigona) testaceicorn?s LEP., M. rufiventris ruficentris LEP., e outras adaptadas a condições ecológicas muito restrictas como a Melipona fuscata melanoventer SCHWARZ, estreitamente limitada à região do baixo Amazonas. Apesar de haver espécies cujas zonas de distribuição geográfica, em certas regiões, se súperpôem, tal seja o caso da $M$. quadrifasciata LEP. e da M. marginata LEP., varificámos que as condições ecológicas escolhidas são um pouco diferentes; assim, a M. marginata LEP. é com mais frequência encontrada nas árvores dos campos, ao passo que a $M$. quadrifasciata LEP. é mais frequentemente encontrada nas matas, especialmente à margem dos rios.

Conforme a região, observámos a predominância de uma ou outra espécie, ou mesmo de duas ou três numa mesma zona, e concluimos que elas deverão ser as mais adaptadas àquelas condições ecológicas. Assim, entre o gênero Melipona há predominância da espécie $M$. quadrifasciata LEP. no sul do país, das espécies $M$. quadrifasciata LEP. e $M$. marginata LEP. nos arredores de São Paulo, de $M$. schencki GRIBODO na região de P. de Caldas, de $M$. fuscata melanoventer SCHWARZ na de Belém, Pará, de $M$. interrupta fasciculata SMITH na região de Carolina, Maranhão, de $M$. favosa FAB. na região de Mato Grosso e Bolívia, etc.

Pela publicação de Michener (1946) vimos que parece existir, entre os meliponíneos, uma tendência de formar concentrações locais de espécies, provavelmente devido às maiores fontes de alimentação e às maiores facilidades de encontrar ôcos passíveis de serem habitados na área em questão; e, também, ao processo de enxameagem do grupo, que não permite a formação de colónias muito afastadas da colónia-mãe. Porém, a expulsão dos machos das colméias e seu ráio de vôo muito maior que o da rainha devem diminuir o efeito da localização agrupada das colónias.

Deixámos, aqui, expostos êstes diversos fatos, porém, voltaremos, mais adiante, a tratar da distribuição geográfica da Melipona quadrifasciata LEP., que se nos apresenta um problema muito interessante.

\section{c) Densidade de população}

Dobzhansky e Wright (1943), para estabelecerem o número de indivíduos por área em Drosophila pseudoobscura FRO- 
LOVA descrevem um método que se resume no seguinte: 1ibertaram, em determinados pontos, 14026 moscas de olhos laranja. Foram colocadas iscas de 20 em 20 metros, ao longo de linhas que se cruzavam em ângulos retos no ponto onde as moscas foram libertadas. Capturaram, nessas iscas, tanto moscas com olhos laranja como selvagens, tendo-se anotado os dados. Com base nesses dados, foi calculada a densidade da população selvagem, que foi estimada em 400 indivíduos por $10.000 \mathrm{~ms}^{2}$, no começo de junho, e 800 por $10.000 \mathrm{~ms}^{2}$ de meados de junho ao fim de julho do mesmo ano (1942). Analisando-se a estrutura da população na base da frequência de alelismo de letais, a "densidade efetiva" da população foi estimada em 50 indivíduos por $10.000 \mathrm{~ms}^{2}$.

Para os himenópteros sociais tal processo de iscas não pode ser adaptado, pois aquí não são os indivíduos genèticamente ativos que vão ter ás fontes de alimento, porém, são as operárias; também, mesmo que o número de operárias atraidas a uma fonte de alimento fosse da mesma espécie, não nos daria qualquer indicação sôbre o número de colónias a que pertencem, havendo alta probabilidade, devido ao seu sistema de comunicação cu "linguagern", de que tivéssemos,em uma certa fonte de alimentos, somente operárias de uma só colónia.

As operárias não entram em nossos cálculos, apesar de, em condições excepcionais, pôrem ovos de onde nascerão só. mente machos. A contagem, tanto das fêmeas virgens como dos machos, que consideramos como "potencialmente ativos", não tem interesse para nós, não só por não interessar à genética de população, como por ser o seu número muito variável com as estaçőes, como demonstrámos para algumas espécies do gênero Melipona (Kerr, 1948). Só nos interessam os indivíduos genèticamente ativos, e, como não pcdemos usar iscas, o único meio de determinar o seu número é contar o número das colméias; considerando como "genéticamente ativos" a rainha fecundada e o macho ou os machos que a fecundaram, devemos multiplicar por $(1+x)$ o número de colónias encontradas, onde $\mathrm{x}$ é o número médio de machos que fecunda uma rainha.

Em Apis mellifera L., a julgar pelos dados de William C. Robert (1944) cerca de $50 \%$ das rainhas sofrem fecundação dupla. Nas zonas apícolas recomenda-se um número máximo de 120 colméias por area de pastagem, portanto o seu número 
de indivíduos geneticamente ativos nessa area será de: 120 $(1+1,5)=300$.

Nos Meliponini, o trabalho mais perfeito sôbre contagem de colónias, em determinadas áreas, é o de Michener (1946, pp. 180-181) em diversas espécies de Meliponini, baseando suas observações em colméias, nas ruinas de Panamá Velha, Panamá. Os dados coletados foram agrupados num quadro, que o Dr. C. D. Michener nos permitiu reproduzir. Para maior clareza dos nossos objetivos, adicionámos, no Quadro III, as duas últimas colunas, que nos dão, uma, os números de colméias por $10.000 \mathrm{~ms} 2$ (calculados sôbre dados da publicação citada) e outra, os números de indivíduos genèticamente ativos por .... $10.000 \mathrm{~ms}^{2}$, que é como dissemos, o dôbro do número de colméias. Mantivemos, neite quadro, a divisão feita por Michener, em 5 zonas, onde se verificou que há, em certas zonas, uma visível concentração de espécies diversas; isto mostra uma preferência das abelhas em estabelecer-se em uma zona determinada; portanto, os dados calculados nas duas últimas colónias são médios, podendo ser bem menores em certas áreas, e, em outras, ser mais elevada como, no quadro, é o caso da Trigona (Nannotrigona) testaceicornis perilampoides CRESSON que, na zona $A$, tem uma densidade de população 2,7 vezes maior que a média calculada. Vemos que a densidade das espécies mais abundante é de, aproximadamente, 1 individuo por $10.000 \mathrm{~ms}^{2}$.

Verificámos que essa é, aproximadamente, a densidade para Melipona marginata LEP. e Trigona (Trigona) ruficrus LAT. em algumas matas das proximidades de Araçariguana e Cabreúva. Em Piracicaba, mesmo na zona urbana, essa é aproximadamente a densidade de Trigona (Tetragonisca) jaty F. SMITH. Em uma mata entre Pirapóra do Bom Jesús e Araçariguama em que estavam procedendo à derrubada, contámos, em um alqueire, 11 colónias de Melipona marginata LEP. e 4 de $M$. quadrifasciata, LEP., o que deu para a primeira espécie uma densidade de, aproximadamente, 4,5 colméias por ...... $10.000 \mathrm{~ms}^{2}$, ou seja, 9 indivíduos genéticamente ativos por .. $10.000 \mathrm{~ms}^{2}$. Entretanto nas matas visinhas a densidade foi bem menor, o que nos levou o considerar êsse excesso como uma aglomeração natural de núcleos devido a facilidades de construção de colónias e de aquisição de alimentos, tal como foi constatado nas observações acima citadas de Michener. 
QUADRO III (1)

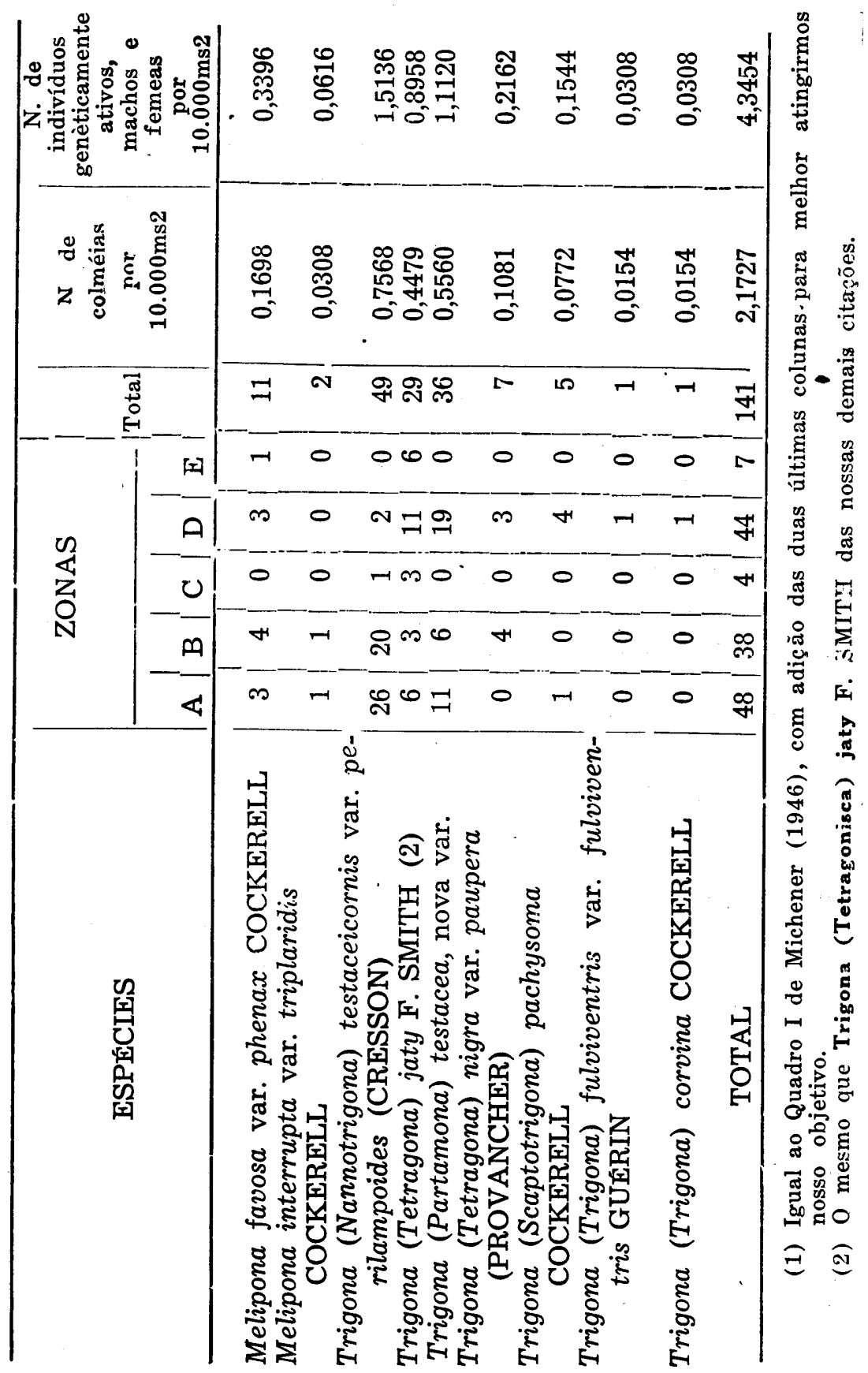


Na região de Sta. Cruz de La Sierra (Bolívia) (1), a espécie de maior densidade é a Trigona (Scaptotrigona) depilis MOURE e T. (S.) bipunctata polysticta MOURE, e, na zona do pantanal, (Mato Grosso), 'as espécies mais frequêntes são: Melipona favosa orbignyi GUÉRIN, Trigona (Oxitrigona) tataira F. SMITH e Trigona (Tetragonisca) jaty fiebrigi SCHWARZ, tôdas, também, da ordem de um indivíduo por $10.000 \mathrm{~ms}^{2}$, aproximadamente.

A densidade de população nos Meliponini é muito constante devido à sua organização social, com reservas alimentares para contrabalançar a variação das fontes de alimentos, e devido ao seu cuidadoso processo de enxameagem, não tendo, como a maioria dos insetos, flutuações de acôrdo com a época do ano. Essa constância concorre sensivelmente para fazer com que os Meliponini sociais estejam, do ponto de vista da densidade da população genèticamente ativa, em quase paridade de condições com muitos outros organismos que variam demasiadamente em determinadas épocas desfavoráveis. Dizemos isso, porque, segundo Wright, (1931), "the effective N (breeding population) is much closer to the minimum number than to the maximum number (pg. 111)"

\section{d) Meios de distribuição}

Na literatura sôbre genética de populações, especialmente de Drosophilas, encontrámos, geralmente incluidos sob êste título, duas espécies de dados : a) a distância média percorrida por um indivíduo em um dia ou em uma outra qualque: unidade de tempo e b) a distância média percorrida por um indivíduo desde o lugar em que nasceu até o lugar em que irá reproduzir-se.

Esta classe de dados é bastante difícil de ser obtida, porém, podemos tecer algumas considerações sôbre o que já fci verificado em algumas espécies dos Apinae.

Apis dorsata FABRICIUS, ou abelha gigante da India, enxameia percorrendo distâncias muito grandes, de muitos quilómetros, o que faz que sua população genèticamente ativa por área de reprodução seja maior. Ha, entretanto, outros fatores que não são muito favoráveis a essa espécie, tal seja a sua adaptação a um nicho ecológico particular.

(1) As abelhas coletadas nessa região foram classificadas por Pe. J. S. Moure, C. M. F. e estão incluidas na sua publicação de 1950 . 
Apis mellifera LINNAEUS: seus enxames vão a distâncias também muito grandes. Êsse fato contribuiu para o rápido estabelecimento dessa espécie na América do Sul, em áreas consideráveis, num espaço de tempo relativamente curto, após sua introdução pelos jesuitas. A enxameação é o meio de distribuição da fêmea, porém, o meio de distribuição do macho é mais interessante do ponto de vista da genética de populações, porque, enquanto a fêmea sofre a fecundação geralmente nas proximidades da colónia mãe, o macho, ao contrario, percorre distâncias consideráveis, procurando uma fêmea para acasalarse. Segundo os comentários de Dadant (1948) aceita-se, comumente, que apiários colocados de 3,2 a $4,8 \mathrm{ks}$. (2 a 3 milhas) distantes de outras abelhas estão livres de acasalamentos indesejáveis; porém, julga-se que os zangões devam alcançar maiores distâncias que as operárias, e estas, se bem que possuam um ráio de atividade normal ao redor de $1 \mathrm{k}$., podem, no entanto, alcançar até a distância de $16 \mathrm{ks}$. Continua Dadant seus comentários dizendo que há dados sôbre abelhas italianas (amarelas) colocadas em uma ilha situada a diversas milhas da costa que copularam comumente com zangões pretos provenientes do continente.

Meliponini - Já verificámos que há, enire certos Meliponini (talvez em todos) o hábito de expulsão dos machos, que pràticamente os obriga a procurar outras colónias. Também, pela maior robustez dos seus torax, podemos deduzir que seus ráios de vôo sejam superiores aos das operarias. Até hoje, as operárias mais retiradas da colónia, que encontrámos, achavam-se a $1 \mathrm{k}$. e $100 \mathrm{~ms}$. e eram de $M$. quadrifasciata LEP. porém, isso não é o limite, pois trata-se de uma observação isolada, numa única fonte de alimentos, mas que prova que o ráio de vôo das operárias de certas Meliponas é, aproximadamente, da mesma ordem que o de Apis melifera L., portanto, o macho, que, pelo indicado pelos seus caracteres anatômicos deve possuir maior ráio de vôo, é o portador da carga genética para grandes distâncias.

Sôbre a distância de vôo dos enxames. (que é o meio de distribuiçâo da fêmea) anotámos, até agora, sómente um dado extremo em Trigona (Tetragonisca) jaty F. SMITH. Houve, em uma de nossas caixas de observação, que na época estava vazia, um enxame dessa espécie. A colónia de $T$ (T.) jaty $\mathrm{F}$. SMITH, mais próxima dessa caixa de observação distava entre 250 a $280 \mathrm{~ms}$., devendo, portanto, a fêmea, ter voado pelo menos essa distância, pois poderia, também, provir de alguma 
colónia mais retirada. Entretanto, uma outra colónia de T. (T.) jaty F. SMITH enxameou de uma de nossas caixas de observação para outra, situada à $20 \mathrm{~ms}$. de distância. Em outra espécie (M. marginata LEP.) temos encontrado agrupamentos de colónias que não distam umas das outras, mais que $100 \mathrm{~ms}$. Acreditamos que, talvez, essa distância $(100 \mathrm{~ms})$ não seja limitada sòmente pelo ráio de vôo da fêmea, mas, também, pelas facilidades de construção de colméias em determinados lugares. Já encontrámos em uma só árvore : 1 colónia de $M$. rufiventris rufiventris LEP., 2 de $M$. quadrifasciata LEP. e 2 de Trigona (Plebeia) mosquito F. SMITH, havendo, na literatura, casos mais extremos como o citado por Schwarz (1948, pg. 12), de 25 colónias em uma só árvore, demonstrando a grande preferência por lugares onde há facilidades para construção de colméias. Baseando-nos em nossas observações, podemos, com reservas, admitir um vôo médio por geração de $100 \mathrm{~ms}$ para os Meliponini de espécies próximas às que estudámos.

\section{e) TAXAS DE MUTAÇÃO}

Infelizmente, não temos dado algum sôbre a taxa de mutação para quaisquer dos gens conhecidos entre os himenópteros sociais. No himenóptero Habrobracsn juglandis ASHMEAD há cêrca de 20 mutantes detectados, porém, todos êstes provocados por ráios $\mathrm{X}$, que aumentam consideravelmente a taxa de mutação.

$\mathrm{Na}$ Apis mellifera LINNAEUS já há diversios gens mutados conhecidos; um ótimo sumário dêsses gens e de suas funções encontramos na publicação de Nolan (1937), às páginas 1411-1415. Nada sabemos, entretanto, da frequência de mutação entre êles.

$\mathrm{O}$ dado da literatura que mais nos chamou a atenção, sôbre Apis mellifera L., foi o de Root (1943, pg. 695) que diz: "Os zangões com cabeça de diferentes côres constituem um dos interessantes fenômenos da história natural. Quase não passa um verão sem que alguma pessoa nos escreva sôbre o assunto, ou nos envie exemplares de zangões que apresentam esta estranha característica. Não sòmente se têm encontrado zangões de olhos brancos, como, também, com cabeça côr de cereja, e, também, verde brilhante, ou, em outras ocasióes, amarela. Por que se observará mais esta peculiariedade nos machos que nas rainhas e operárias, e mais, por que será a cabeça a única parte do corpo sujeita a essa mudança de côres ?" Por aí vemos que, apesar de não haver dados quantitativos, temos uma indi- 
cação de que, para certos gens, a taxa de mutação não deve ser muito báixa. Não podemos afirmar que as taxas de mutação para os gens que afetam a cabeça sejam maiores que para os demais gens; parece-nos que tais mutações têm sido detectadas mais frequentemente, porque um macho que tivesse afetado o tamanho da asa, por exemplo, não teria probabilidade de vir a ser observado pelo apicultor, a não ser por medições comparativas; o mesmo não acontece com os gens que afetam a côr da cabeça, que poderão ser fàcilmente percebidos pelos apicultores. A outra pergunta de Root: "Por que são os machos mais afetados ?", tem uma resposta na natureza haploide dos mesmos, sendo, êste, um ponto a que nos reportaremos mais adiante.

Para a determinação da taxa de mutação podemos usar processos matemáticos, partindo dos gens mutados que já encontramos presentes nas populações selvagens. Em espécies com reprodução panmitica, como em Drosophila, êste meio é muito utilizado, postulando-se, porém, que as mutações sejam sempre para gens recessivos subviáveis. Neste caso, pode-se empregar uma fórmula de Haldane (1937b, Apud Brieger 1950):

$$
u=q^{2}(1-R a)
$$

oñde u é a taxa de mutação de A para a, $q^{2}$ é a frequência dos homozigotos-duplo-recessivos (aa), e Ra é o índice de sobrevivência dêsses recessivos.

Em vista, porém, da possibilidade de muitos aleles subviáveis recessivos possuirem efeito heterótico, achamos que essa fórmula deve ser substituida pela fórmula mais geral :

$$
u=q^{2}(1-R a)-p q(1-R A)
$$

pois a primeira é um caso especial desta última, desde que consideramos $\mathrm{RA}=1$.

Do exposto, fica evidente que, também nos Hymenoptera devemos achar diferentes fórmulas, se quisermos avaliar a taxa de mutação, a partir dos gens mutados.

A influência da taxa de mutação varia de acôrdo com os métodos e hábitos de reprodução exibidos por uma espécie ou grupo. Assim, verificaremos, para os himenópteros, qual será a fórmula da taxa de mutação, em termos de q (frequência do gen mutado (a) na população das fêmeas) e s (frequência do gen (a) na população dos machos) e dos índices de sobrevivência RA e Ra.

Supomos que a mutação se dá de $A$ para a com uma taxa de mutação (u), desprezando as mutações de $a$ para $A$ (mưtações recurrentes) para não complicar os cálculos. 


\begin{tabular}{|c|c|c|}
\hline & 99 & 88 \\
\hline Gens que formoröo $P_{n}$ & $D(A) \quad q(a)$ & $r(A) \cdot(a)$ \\
\hline Populaçăo $P_{n}$ & $\operatorname{pr}(A A)+(p s+q r)(A Q)+q s(0 Q)$ & $P(A) Q(0)$ \\
\hline $\begin{array}{l}\text { Populoģão } P_{n} \\
\text { após o soleção }\end{array}$ & $\left(p r R_{A}\right) A A+(p B+q r) A O+\left(q \& R_{0}\right) 0 \delta^{\prime}$ & $P R_{A}(A) \quad Q R_{a}(a)$ \\
\hline $\begin{array}{l}\text { Gens que formoröo } \\
P_{n+1} \text { supondo-se que } \\
(p) \bullet(r) \text { mutarom } \\
\text { respectivomente poro } \\
(q) \bullet(s) \text { numa toxo }(u)\end{array}$ & $\begin{array}{l}{\left[p r R_{A}+\frac{p \varepsilon+q r}{2}-u(p+r)\right] A+} \\
+\left[q \& R_{0}+\frac{p s+q r}{2}+u(p+r)\right] 0\end{array}$ & $\begin{array}{l}\left(P R_{A}-u p\right) A+ \\
+\left(q R_{0}+u p\right) 0\end{array}$ \\
\hline
\end{tabular}

$$
\frac{p}{q}=\frac{p r R_{A} \frac{p s+q r}{2}-u(p+r)}{q s R_{a}+2+u(p+r)} \text { (GA) } \frac{p s+q r}{s}=\frac{p R_{A}-u p}{q R_{0}+u p}
$$

No equilíbrio, teremos que a população $\mathrm{Pn}$ será igual à população $\mathrm{Pn}+1$. Portanto, obtemos as proporções (64) e (63)

Da equação 65, que é mais simples, podemos extrair a seguinte fórmula para $\mathrm{u}$, em termos dos indivíduos recessivos.

$$
\mathrm{u}=\mathrm{s} \cdot \mathrm{RA}-\mathrm{q} \cdot \mathrm{Ra} \frac{1-\mathrm{s}}{1-\mathrm{q}}
$$

Estudaremos, agora, alguns casos mais comuns, para verificar o comportamento da fórmula, 66 comparando-a a situações idênticas, em populações panmíticas diploides.

1) Gens heteróticos, isto é, quando $1>\mathbf{R A} \supseteq \mathbf{R a}$.

Em populações panmíticas de himenopteros teremos de aplicar a mesma fórmula 66. A fórmula correspondente em populações panmíticas diploides é :

$$
\mathrm{u}=\mathrm{q}^{2}(1-\mathrm{Ra})-\mathrm{pq}(1-\mathrm{RA})
$$

2) Gens subviáveis recessivos, isto é, quando $1=R A>R A$. Em populações panmíticas de himenópteros teremos, substituindo na fórmula (66) RA por 1. 


$$
\mathrm{u}=\mathrm{s}-\operatorname{Raq} \frac{1-\mathrm{s}}{1-\mathrm{q}}
$$

Para populações diploides, a fórmula correspondente seria:

$$
\mathrm{u}=\mathrm{q}^{2}(1-\mathrm{Ra})
$$

3) Gens letais recessivos, isto é, quando $R A=1, R a=0$ A fórmula (66) tornará a seguinte expressão:

$$
\mathbf{u}=\mathbf{s}
$$

A fórmula correspondente em populações diploides será :

$$
\mathrm{u}=\mathrm{q}^{2}
$$

Já elaborámos planos para a verificação da taxa de mutação em abelhas procurando aplicar a fórmula (68).

Poderá parecer estranho não nos termos utilizado da segregação feminina, porém, a razão por que assim procedemos é que, a partir da população feminina, chegaremos a fórmulas extremamente complicadas. Para darmos um exemplo, calcularemos o valor de " $a$ " em função de " $q$ " para gens letais recessivos, não heteróticos. Assim, a equação (64) se tornará :

$$
\frac{p}{q}=\frac{\frac{p s+q r}{p r+2-u(p+r)}}{\frac{p s+q r}{2}+u(p+r)}
$$

Substituindo, nesta equação, p por $1-q, r$ por $1-$ s e s por u (segundo a fórmula 68 ) teremos a seguinte equação de segundo gráo :

$$
\begin{array}{r}
-2(1-q) u^{2}+\left(6 q^{2}-9 q+5\right) u-\left(q^{2}+q\right)=0 \\
\therefore u=\frac{-\left(6 q^{2}-9 q+5\right)+\sqrt{\left(6 q^{2}-9 q+5\right)^{2}-8(1-q)\left(q^{2}+q\right)}}{-(1-q)}
\end{array}
$$

Este exemplo nos mostra a complexidade da fórmula de $u$, quando calculada em função dos genótipos femininos. 
f) Estrutura e comportamento do mecanismo cromossômico

A ordem Hymenoptera, na sua quase totalidade, possui um mecanismo cromossômico haplo-diplóide, isto é, os machos são haplóides, oriundos de oosferas não fecundadas, e as fêmeas são diplóides, provenientes de oosferas fecundadas. Algumas das influências desta circunstância foram analisadas na primeira parte desta tese, e, daí, podemos aquilatar sua grande importância, As abelhas sociais, como himenópteros, estão sujeitas à sua atuação. Entre elas, porém, um dos gêneros, o gênero Melipona adiciona à complicação do sisiema haplo-diplóide, mais uma, que é a de possuir como determinador da casta feminina fértil (e, portanto, da metade da população genèticamente ativa) um mecanismo duplo e triplo-híbrido, conforme a espécie, isto é, respectivamente, Melipona marginata LEP. (duplo) e as demais analisadas triplo, que são: M. quadrifasciata. LEP. (subespécies quadrifasciata LEP. e anthidioides LEP.), $M$. rufiventris (subespécie paraensis DUCKE), $M$. interrupta (subespécie fasciculata F. SMITH), Melipona favosa (subespécie orbignyi GUéRIN),M. fuscata (subespécie melanoventer (SCHWARZ), M. flavipennis F. SMITH e M. schencki GRIBODO).

Êsse mecanismo, que já foi por nós descrito e comentado em publicações anteriores (Kerr, 1946,1948, 1950a e b), consiste, ràpidamente, no seguinte : Tôdas as fêmeas homozigotas para um, dois ou três fatôres determinantes de casta ( $A$ ou a e $\mathrm{B}$ ou b) em Melipona marginata LEP. e A ou a, B ou b e C ou c nas demais estudadas) serão operárias, e as fêmeas dupla $(\mathrm{AaBb})$ ou triplo heterozigotas $(\mathrm{AaBbCc})$ para os mesmos fatôres, serão rainhas. Não podemos, entretanto, dizer, pela falta de gens ligados, ou outro método qualquer, se os fatôres $\mathrm{A}$, B ou C são simples gens, regiões, ou todo um cromoss oma. Achamos, entretanto, mais provável que se trate de regióes cromossômicas por dois motivos: 1) os loci situados muito próximos ao fator principal terão pouca ou nenhuma probabilidade de se desligarem por "crossing over". 2) Os efeitos desses fatôres são em tão grande número, que nos fazem supôr estarmos diante, ou de gens altamente pleiotrópicos, ou de regióes cromossômicas carregando diferentes fatôres. Da ação múltipla do fator para casta (gen ou região) podemos citar o seguinte exemplo em Melipona quadrifasciata LEP., comparando a rainha à operária. 
1) A cabeça é grande na operária e pequena na rainha; 2) os olhos da rainha são elípticos como os das operárias, porém, mais curtos e mais esireitos; 3) o comprimento total da língua é, ao redor, de $5,95 \mathrm{mms}$. para as operárias e $4,11 \mathrm{mms}$. para as rainhas (Quadro IX) ; 4) o mesonoto da rainha é liso, desprovido da superfície finamente reticulada e pontuada, observável na operária; 5) as pernas das operárias são pretas e as das rainhas são marron-escuras; 6) a tíbia trazeira da rainha é muito mais estreita e de diferente forma (não triangular) que na operária; 7) a largura do tórax da rainha é, ao redor, de $3,5 \mathrm{mms}$. e, na operárias, entre 3,8 e $4,8 \mathrm{mms}$; ; $)$ o comprimenio da asa anterior (incluindo a tegula) é, na rainha, ao redor, de $6,25 \mathrm{mms}$. e, na operária, de 7 a $8 \mathrm{mms}$. (Schwarz, 1932); 9) o abdómen da rainha é marron, enquanto que, nas operárias, é castanho escuro, com largas bandas amarelas nos tergitos metasomáticos 2-5, completas ou interrompidas conforme se trate das subespécies quadrifasciata LEP. ou anthidiodes LEP.; 10) o comprimento dos ovários de rainha virgem é 5 a 6 vezes maior que o da operária, e o da rainha fecundada idosa, 30 ou 40 vezes; 11) o casulo tecido pela rainha é mais delgado que o da operária, demonstrando que suas glândulas serígenas são menos desenvolvidas; 12 ) a rainha é mais precoce que a operária, tanto para iniciar a pigmentação, como para emergir; 13) por pesagens de centenas de pupas (a ser publicado) verificámos que as pupas de rainhas perdem pêso mais ràpidamente que as de operárias; 14) os instintos são completamente diferentes. Além desses 14 caracteres citados, outros mais deverão, certamente, existir, porém, achamos suficiente demonstrar a ação dos fatores determinantes de casta nesses pontos.

Após estas considerações, não podemos excluir a hipótese de os fatores casta-determinantes do gênero Melipona, serem regiōes cromossômicas, e, portanto, incluir-nos neste $7^{\circ}$. ponto em estudo. A origem de tais regiões, se foram por duplicações e mutações posteriores diferentes dos locus duplicados, ou se foram por mutações dos locus vizinhos à mutação inicial, é assunto que de modo algum podemos decidir.

Tôdas as espécies de Melipona que estudámos citológicamente até hoje apresentaram 9 cromosomas no macho e 18 nas fêmeas ( $M$. marginata LEP., $M$. quadrifasciata LEP., $M$. rufiventris ruficentris LEP., $M$. schencki GRIBODO, $M$. interrupta fasciculata F. SMITH). Verificámos, assim, que, por êsse mecanismo determinador de castas, $1 / 3$ do genoma feminino fica com regiões cromossômicas heterozigotas. 
Como descrevemos nas publicações citadas, há um grande excesso de rainhas $(12,5 \%$ e $25 \%)$ que são, contínua e quase totalmente, eliminadas pelas operárias. Um tal perda necessita de ser equilibrada por algum outro mecanismo compensador, e, por tôdas as indicações que possuimos, o mecanismo que equilibra tal situação é o da obrigatoriedade de a fêmea heterozigota ser a fêmea fértil. Outros organismos estudados, como as Drosophilas, também se utilizam de mecanismos cromossômicos (inversões) para manterem a heterozigotia (Wrigth e Dobzhansky, 1946). Tanto as inversões em Drosophila, como a situação encontrada no gênero Melipona se acham estrictamente relacionadas com a heterose.

Um outro mecanismo cromossômico interessante foi o recentemente descorberto por Manning (1948), que constatou a existencia de um cromossoma sexual (chamado por Manning de cromossoma X) em Apis mellifera L. sôbre o qual nos referiremos com mais detalhe no $1^{\circ}$. capítulo da III parte.

\section{II - FATORES SELETIVOS IMPORTANTES}

Fizemos, nos capítulos anteriores, por diversas vezes, referências ao efeito da seleção, tendo-nos utilizado, como medida da sua intensidade, dos índices de sobrevivência. Discutimos, na 1a. parte desta tese, o aspecto matemático dêsse problema, e agora trataremos mais de perto de alguns fatores bionômicos envolvidos na determinação dêsses índices de sobrevivência.

Tomaremos, em consideração especial, dois fatores seletivos, considerados por May (1947, pg. 271 e 272) como os principais na diferenciação de espécies incipientes: Competição e predação.

\section{a) Competição}

Apesar de análise dos diversos fatores que afetam a competição entre as abelhas sociais ser muito difícil, muitos deles podendo ser confundidos com os que já estudámos afetando a capacidade evolutiva, citaremos os seguintes, que são de suma importância : capacidade de vôo e de coletar alimento das operárias, e postura da rainha.

A capacidade de vôo é de muita importância devido ao fato de possibilitar às operárias o transporte de uma maior quantidade de alimentos e obtê-los de uma maior área. Os gêneros 
Melipona, Apis e Bombus e algumas Trigonas possuem suas asas construidas segundo um plano geral, porém, em grande número de espécies de Trigonas, principalmente dos subgêneros Hypotrigona, Plebeia, Friesella, Schwarzula e Scaura, notámos uma grande redução na venação das asas, principalmente das veias distais. A explicação de como se poude estabelecer um acontecimento dessa natureza, aparentemente desvantajoso para as abelhas, foi muito bem dada por Michener (1944, pg. 219) como segue: "Além de certo ponto, tais reduções poderão constituir-se em desvantagens para as abelhas grandes ou médias, por, talvez, tornar as asas demasiadamente frágeis; porém, tais mutações poderão estabelecer-se quando o tamanho das asas for grademente reduzido em espécies diminutas".

A capacidade de coletar alimentos varia conforme a classe de alimentos a ser coletado: mel ou pólen. Na coleta do mel, dois fatores são importantes : o comprimento da língua e o tamanho da abelha. Sôbre o primeiro, não precisamos comentar, pois já foi de há muito percebido pelos apicultores e melhoristas, os quais têm feito diversos levantamentos sôbre o comprimento da língua das operárias em diversas raças de Apis mellifera L. (literatura em Alpatov, 1929, e Nolan 1937). Fizemos, também, algumas medidas na espécie $M$. quadrifasciata LEP. e verificámos que os futuros criadores de Meliponini precisam dar bastante atenção a êsse ponto, pois a variação de colónia para colónia é bastante grande, como podemos vêr pelas seguintes médias encontradas em três de nossas colónias : colónia $8=5,34 \mathrm{mms}$; colónia $35=5,76 \mathrm{mms}$; colónia $40-\mathrm{B}=5,95$ mms.

Ainda sôbre a língua das abelhas podemos nos referir a capacidade que as abelhas do gênero Bombus possuem de perfurar certas flores com suas línguas, pelo lado de fora, para mais fàcilmente alcançarem os nectários.

Citámos o tamanho da abelha em conexão com êste assunto devido às nossas observações seguintes : verificámos que certas flores, como, por exemplo, certas espécies de Flox, de Nicotiana, de Liliaceae, de Bignonaceae, etc.) algumas normalmente visitadas por borboletas, sendo as abelhas grandes, incapazes de tirar-lhes o nectar, são exploradas pelas Trigonas diminutas, pois, apesar de suas línguas serem muito pequenas, essas abelhas podem aproximá-la muito mais da fonte de nectar por caberem fàcilmente no tubo formado pelas pétalas.

Quanto à colheita de pólen, as abelhas sociais comportamse quase tôdas da mesma maneira, utilizando-se das corbículas. Porém, há uma exceção que queremos mencionar : trata-se do 
gênero Lestrimelitta. Essse gênero possui a face exterior da tíbia traseira com superfície uniforme, um tanto abaulada para fora, portanto, desprovida da concavidade apropriada à coleta do pólen : a corbícula.

Essa abelha é conhecida pelos seus hábitos belicosos, e foi, mesmo, tida por alguns pesquisadores (Müller, 1874) como incapaz de autosustentar-se, a não ser pelo saque. Porém, Fiebrig (1908), tendo colocado uma colónia de Lestrimelitta limão F. SMTIH em um vaso de vidro, poude observar que algumas operárias voltavam do campo carregadas de pólen.

Constatámos, nessa mesma espécie, que o método utilizado pelas operárias para o transporte do pólen das colméias saqueadas é o seguinte: primeiramente, secretam um líquido, de sabor muito ácido, que torna a massa de pólen pastosa. Dessa forma é ingerido e transportado, no estômago, para sua própria colméia. Esse relato verificámos quando a Lestrimelitta roubava pólen dos potes. Mais tarde, fizemos, na colméia de Lestrimelitta e em uma de $M$. quadrifasciata LEP., a seguinte experiência: Jogávamos pólen de T.(T) jaty F. SMITH sôbre o favo de filhos e, imediatamente, as operárias iniciavam a mesma operação descrita, i.e, secretavam um líquido que formava uma papa com o pólen e ingeriam-no, para irem depositá-lo nos potes. O pólen saqueado, quando depositado nos potes, não apresenta o aspecto de pequenos glóbulos aglomerados, provenientes das corbículas, porém, apresenta-se em um estado semi-líquido. As vezes, as operárias colocam tal pólen em potes para mel, tornando, assim ainda mais desagradável, o mel das Lestrimelittas, que já não é muito bom.

Nogueira-Neto (1949) verificou que operárias saqueadoras de $M$. quadrifasciata anthidioides LEP. roubavam "mingau alimentício". Temos a impressão de que êsse "minguau" nada mais é que o pólen misturado com a secreção da própria abelha, conforme observámos em Lestrimelitta, sendo, próvavelmente, um processo geral utilizado pelos Meliponini para retransporte de pólen já armazenado. Êsse seria, também, o processo para transporte de pólen durante a enxameação.

A capacidade de postura da rainha é de extrema importância para as abelhas, pois, como cada operária produz muito mais que consome, quanto maior for a postura, tanto maior será a reserva de alimentos para a manutenção da colónia em épocas más. Esses detalhes já são sobejamente conhecidos dos apicultores que, ao comprarem suas rainhas, exigem, como principal condição, a de serem de linhagens de alta postura. Também temos verificado que, em caso de luta entre colónias, 
o número de abelhas é muito mais eficiente que o seu tamanho; assim, já verificámos o desalojamento de uma colónia de Apis mellifera L. por uma de Trigona (Tetragonisca) jaty F. SMITH; apesar de esta última ser extremamente menor que a primeira, seu número era muito superior. Comumente, uma abelha de T. (T.) jaty F. SMITH agarra-se à asa, antena ou perna de uma abelha de Apis e, apesar de a não matar imediatamente, impede-a de voar, vindo, ambas, a perecer pelas formigas que geralmente se aproximam do local da luta.

Temos verificado, tanto na zona de Piracicaba como na dos municípios de S. Roque, Parnaiba e Cabreúva, que as Meliponini mais comuns são: Trigona (Plebeia) mosquito F. SMITH, T. (Tetragonisca) jaty F. SMITH e T. (Scaptotrigona) pectoralis DALLA TORRE e em contagem que fizemos, de suas posturas, verificámos serem superiores às da $M$. marginata LEP. e esta, superior à $M$. quadrifasciata LEP. sendo, aproximadamente, esta a ordem de freqüência das colónias na região.

Encontramos numa mata da Serra do Japy (Município de Cabreúva) cerca de 25 espécies diferentes de Meliponini que, pelo fato de explorarem um grande número de flores em comum, forçosamente competem umas com as outras. Também mais da metade dessas espécies possuem preferências idênticas para localização da colônia. Como êsse fato, de serem encontradas diversas espécies numa mesma zona, é geral nos trópicos e subtrópicos, queremos citar as três variáveis que, segundo $\mathrm{Cu}-$ nha, Burla e Dobzhancky (1950) controlam a variedade de habitantes dominados: 1) O número de nichos ecológicos potencialmente utilizáveis para uma dada forma de vida em uma dada região; 2) uma espécie tem maiores probabilidades de controlar mais nichos ecológicos no território que habita há mais tempo do que um recentemente colonizado; e 3) Presença de espécies competidoras com necessidade ecológicas semelhantes. claro que esta última variável diminuirá os habitantes disponíveis e como inclui o nosso caso, podemos dizer que é um dos fatores responsáveis pela baixa densidade de população entre os Meliponini.

Para terminar êste capítulo sôbre a Competição, queremos acrescentar algumas considerações tecidas por Mayr sôbre êsse assunto.

Sôbre a competição , Mayr (1942) postula que: a) uma forte competição é um fator retardante na evolução; b) diversas famílias evoluiram e diferenciaram-se muito ràpidamente em certas regiões por encontrarem, aí, muitos nichos ecológicos disponíveis. Documentando seus pontos de vista, Mayr dá 
alguns exemplos, dos quais citaremos, por nos interessarem diretamente, um, de Worthington, 1940 (Ap. Mayr o. c.) sôbre o cyprinideo do gênero Engraulicypris, de hábitos pelágicos, que, com diversas subspécies e espécies allopátricas, habita em diversos lagos do este africano. No lago Edward, entretanto, êsse gênero é ausente, e o mesmo nicho ecológico é ocupado pela espécie Haplochilichthys pelagicus, a qual abandonou o "hábitat" usual dos Cyprindontes, de viver nas margens e nos pântanos, para ter uma verdadeira existência pelágica. A lição importante dêste fato é que a competição teve uma influência decisiva na especiação no lago Edward.

Em têrmos de Sewall Wright, a ausência de competidores aparentemente facilita o cruzamento de vales entre um pico adaptativo e outro (Mayr o. c.).

Entre os Meliponini e Apini podemos, também, sugerir que uma competição mais acentuada diminua a intensidade da especiação evolutiva. Assim, os Apini, por se terem conservado no continente Eurasiático, onde a competição já devia ser muito grande, teriam sido impedidos de se diferenciarem muito, dando um único gênero, Apis, com menos de 10 espécies. Por outro lado, os Meliponini, que emigraram para o continente americano, e se expandiram para a Africa e Oceania, desenvolveram-se devido ao relaxamento da competição e devido ao grande número de nichos ecológicos disponíveis, em centenas de espécies agrupadas no mínimo em três gêneros: Lestrimelitta, Trigona eMelipona (segundo Schwarz 1948). Na India, onde temos idênticas condições tanto para os Apini como para os Meliponini, existem três espécies de Apis (Apis mellifera indica), Apis dorsata FABRICIUS e Apis florea FABRICIUS) é também três espécies de Trigona: Trigona (Tetragona) iridipennis iridipennis F. SMITH,Trigona (Tetragona) smithii C. T. BINGHAM eTrigona (Lepidotrigona) ventralis subespécie arcifera $\mathrm{CO}$ CKERELL (Schwarz, 1939).

\section{b) Predação}

Nesse sentido, os Meliponini oferecem duas particularidades interessantes: 1) com exceção de uma espécie, Trigona (Oxytrigona) tataira F. SMITH com suas 6 subespécies (Schwarz 1948) nenhuma outra espécie conhecida possui aparelho venenífero; 2) são de vôo muito lento, algumas como as Trigona (Trigona) trinidadensis PROVANCHER, Trigona (Trigona) ruficuns LAT., Trigona (Trigona) hyalinata LEP., Trigo- 
na (Geotrigona) mombuca F. SMITH, etc., são de uma lentidão espantosa, deixando-se aprisionar com a mão com extrema facilidade.

Isso nos leva a perguntar como puderam tais indivíduos suportar a predação, por parte de diversas aves (e. g. Satrapa icterophys VIEILLOT, Cephloeus lineatus LINNAEUS, (1), Guira guira GMELIN, Dendrocolaptes picumnus LICHTENSTEIN, Tyrannus melancholicus VIEILLOT, Pitangus sulphuratus maximiliani CABANIS e HEINE, picideos em geral, etc.) que, em certos lugares, consomem grandes quantidades de zangões de Apis mellifera LINNAEUS e de exemplares de Meliponini, e de animais como as iraras (Tayra barbara L.) e outros organismos, possuindo essas duas deficiências de capital importância para sua preservação.

Sem dúvida, a preservação individual e coletativa dos $\mathrm{Me}$ liponini depende de outros meios de defesa desenvolvidos pelo grupo, dos quais citaremos:

a) reservas de cera misturada com gomas vegetais para, na hora da luta, empastarem ou mesmo embalsamarem seus inimigos, sistema êsse muito utilizado por espécies dos sub-gêneros Plebeia, Tetragona, Tetragonisca, etc.

b) Mandíbulas muito reforçadas de maneira a decepar um inimigo fàcilmente, destacando-se, com êste característico, as espécies Trigona (Trigona) trinidadensis PROVANCHER, T. (T.) hyalinata LEP., T. (T.) amalthea OLIVIER, e um grande número de espécies do gênero Melipona (Marianno Filho, 1910).

c) Gôsto e cheiro desagradável devido a secreções de glândulas especiais; essa propriedade é considerada como primordial por Marianno Filho (op. c.), o qual diz haver correlação entre as espécies de colónias de maior população com as de possuidoras de princípio odorífero mais ativo (o.c. pg. 8). Constituem bons exemplos desta modalidade de defesa as espécies dos sub-gêneros (Trigona), (Scaptotrigona), a espécie Melipona marginata LEP. e outras.

d) Ataque massiço, contra qualquer intruso, enrolando-se nos seus pêlos ou cabelos, penetrando, devido a um melanotropismo, nos orifícios do nariz e ouvidos. Exemplos bem caracte-

(1) Schwarz (1938), pg. 505) chegou a descrever uma espécie Trigona (Hypotrigona) ceophloei SCHWARZ por exemplares encontrados, em tôdas as fases de seu desenvolvimento, no estômágo de um picapau, Ceophloeus lineatus L., que havia engulido, também, exemplares de Trigona (Hypotrigona) duckei FRIESE. 
rísticos dessa propriedade temos na maioria das espécies dos sub-gêneros Scaptotrigona, Trigona, Partamona eoutros.

e) Número grande de operárias - as vantagens de um número grande de operárias já foram discutidas mais atrás; por isso, citaremos, sòmente, algumas espécies que se destacam nesse sentido: Trigona (Tetragonisca) jaty F. SMITH, Trigona (Scaptorigona) pectoralis DALLA TORRE, Trigona (Trigona) hyalinata LEP., etc.

f) Entradas individuais seguidas de um pequeno túnel, antes de chegar ao lugar onde estão os filhos e pr vvisões. Essas medidas defensivas são encontradas em tôdas as espécies do gênero Melipona que conhecemos e em diversas espécies do gênero Trigona como por exemplo: Trigona (Tetragona) silvestrii FRIESE.

g) Fechamento do orifício de entrada à tarde, para reabrílo na manhã do dia seguinte, evitando predadores noturnos: êste processo é utilizado pelas trigonas menores e mais tímidas, como, por exemplo: colónias fracas em geral, Trigona (Friesella) schrottkyi FRIESE, Trigona (Plebeia) mosquito F. SMITH (observámos sòmente em determinadas colónias), etc. As espécies mais bravias possuem orifício de entrada muito largo e mantêm-no aberto à noite, como acontece com as espécies dos sub-gêneros Scaptotrigona e Trigona.

h) Bloqueamento de entrada com cêra ou resina. - Segundo Fiebrig (em Maidl, 1934) as operárias de Lestrimelitta limáo F. SMITH colocam à entrada do ninho pequenos blocos de cêra para impedir a entrada de formigas (Camponotus ?). Quando o perigo passa retiram a cera para outros mistéres. Maidl (1934, pg. 317) refere-se também ao hábito da Melipona canifrons (sic), que faz um anel de resina à entrada para o mesmo fim, renovando-o constantemente.

i) Em Trigona (Tetragona) silvestrii FRIESE, as operárias, quando atacadas, fingem-se mortas, por uma imobilidade momentânea (1).

Entretanto, achamos que todos êsses meios de defesa seriam insuficientes para preservar um grupo se não houvesse algum método adicional que as encobrisse das vistas dos predadores; por essa razão e pelos fatos observados, consideramos o disfarce da colónia e o mimetismo como um dos agentes mais eficazes na preservação dos Meliponini. Citaremos, consubstanciando êsse ponto, os seguintes fatos:

(1) Segundo informação verbal do Dr. Paulo Nogueira Neto. 
a) Encontramos, em diversas èspécies do gênero Melipona, especialmente na Melipona quadrifasciata LEP. que temos observado com mais detalhe, o hábito de construirem uma porta de entrada de barro, com um formato especial, formando uma escultura em alto relêvo, de formação radial (Fig. 4). Afastados do orifício de entrada, as operárias colocam pequenos amontoados de barro até um espaço de $30 \mathrm{cms}$. de ráio, aproximadamente, chegando, às vezes, a rodear totalmente a região da árvore em que se encontram. Passados 3 a 6 meses, nas matas, êsse sistema de barro é infestado por musgos, algas, liquens, etc., que disfarçam a entrada do ninho, confundindo-a com as formações da casca da árvore. Comumente, o material usado para êsse sistema consta de dejecções animais, provàvelmente para ser infeccionado mais ràpidamente.

Em Trigona (Partamona) testacea subspécie helleri FRIESE Ihering (1903) descreve o hábito que possui essa abelha de construir a colméia preferencialmente entre bromeliáceas, quer arbóreas quer terrestres, e, como exemplo, cita tôdas as 5 colméias que recebeu de diferentes lugares. Também, podemos considerar êste fáto como disfarçamento, pois a finalidade aparente de uma tal construção é confundir o ninho com os detritos que sempre se acumulam na base das bromélias nativas (Fig. 5) .

b) Tôdas as rainhas das espécies que conhecemos do gênero Melipona possuem uma coloração uniforme pràticamente igual à coloração da cera utilizada pela respectiva espécie, tornando mais difícil a encontrar a rainha que as operárias.

c) Diversas espécies de Meliponini possuem um mimetismo muito grande em relação a outra espécies de abelhas e vespas; as espécies "copiadas" são quase sempre bravias e possuem acúleos bem desenvolvidos. Os seguintes exemplos podem ser citados :

I - Trigona (Trigona) hyalinata LEP., T. (T.) rufirus LAT., T. (T.) trinidadensis PROVANCHER, T. (Geotrigona) mombuca F. SMITH, Trigona (Trigona) fulviventris GUéRIN, etc. que imitam algumas abelhas solitárias dos gêneros Tetrapedia (especialmente da espécie Tetrapedia diversipes KLUG) e Paratetrapedia.

II - Melipona quadrifasciata LEP., M. quinquefasciata LEP., M. favosa orbignyi GUéRIN, $M$. favosa favosa FABRICIUS, $M$. favosa lunulata FRIESE, $M$. favosa baeri VACHAL.

(1) Segundo informação verbal do Dr. Nogueira Netto. 
Melipona interrupta grandis GUéRIN (1), M. mandacaia F. SMITH que imitam, principalmente pela coloração do abdómen, abelhas solitárias do gênero Epanthidium (1), Diadasia, Megachile (2), Ptilitrix (2), Thygater; as bandas amarelas do abdómen constituem patrimônio comum também a muitas outras abelhas solitárias.

III - Trigona (Tetragona) clavipes FABRICIUS e Trigona (Tetragona) varia LEP. que imitam com perfeição, especialmente a primeira, indivíduos da espécie Paratetrapedia lineata SPIN.

IV - Melipona fluvipennis F. SMITH (3) imita, não só no seu tamanho, como na maneira de voar, as operárias das Bombus inteiramente pretas, sendó, à primeira vista, extremamente parecidas com as operárias pequenas de $B$. morio (Sw.), $B$. solus FRANKLIN, B. atratus FRANKLIN, B. niger FRANKLIN, etc.

V - Melipona scutelaris scutelaris LAT. e Melipona interrupta fasciculata F. SMITH, imitam, na coloração do corpo, fêmeas da espécie Melitoma euglossoides LEPELETIER e SERVILLE.

VI - Melipona rufiventris LEP. e suas subespécies imitam exemplares de Hemisiella lanipes (FAB.) e Hemisiella hoplopoda (MOURE).

VII - Lestrimelitta limão F. SMITH apresenta-se com formas vespoideas, afastando-se do tipo comum entre os Meliponini.

(1) Nos municípios de Piracicaba, 'S. Roque, Cabreúva e Parnaiba co-existem Melipona quadrifasciata anthidioides LEP. e espécies de Epanthidium. Packard (1869 pg. 59, Apud Schwarz, 1948, pg. 77) classificou um exemplar de Melipona interrupta grandis GUéRIN como sendo Anthidium pictifrons devido às bandas e maculações do abdómen, e outros caracteres. Neste caso, o mimetismo enganou até ao sistemata.

(2) Em S. José de Chiquitos (Bolívia) coletámos diversas abelhas, julgando serem tôdas diversos exemplares de M. favosa baeri VACHAL, e M. favosa lunulata FRIESE, porém, verificámos que, entre elas, havia diversos exemplares de Megachile (Chrysosarus) sp., e Ptilothrix relata (HOLMBERG). Em Guaicurús fizemos idêntico'engano, com exemplares de M. favosa orbignyi GUéRIN e uma outra espécie do mesmo gênero de abelha solitária Megachile (Chrysosarus).

3) Devido a semelhança com Bombus, muitas vezes as colónias de Melipona flavipennis F. SMITH são preservadas pelos sertanejos nortistas e nordestinos. Nos arredores de Belém e Guamá (Pará) verificámos diversas pessôas com a crença errônea de que a M. flavipennis F. SMITH seria provida de acúleo fortemente desenvolvido. 
VIII - As M. marginata LEP., quando coletando mel e pólen, são fàcilmente confundíveis com diversas abelhas solitárias das quais podemos citar a espécie Acamptopoeum flavifrons (F. SMITH), espécies do gênero Exomalopsis e espécies da tribu Dianthidiinae.

IX - operárias de Trigona (Tetragona) silvestrii FRISE e Trigona (Trigona) dimidiata SMITH possuem azas escuras com suas extremidades incolores, imitando vespas do gênero Chartergus e algumas Eulema. A posição das azas das operárias de T. (Tetragona) silvestrii FRIESE, quando estão movimentando-se ou quando estão coletando alimentos imitam também certas vespas.

Julgamos que deve haver muito mais casos de mimetismo entre os Meliponini que ainda não foram ${ }^{-}$devidamente analisados. Queremos, para evitar dúvidas, frisar que as espécies de abelhas solitárias que citámos são tôdas de idêntica distribuição geográfica que as espécies miméticas.

Por aí podemos concluir ser o mimetismo um dos principais meios de defesa dos atuais Meliponini; cremos que uma grande quantidade de espécies tenha sido dizimada pelos muitos predadores, tendo sobrevivido sòmente as que apresentavam meios mais eficientes de defesa, como os que citámos.

Achámos muito razoável a existência de mimetismo entre os Meliponini, imitando as abelhas mais ferozes, pois, se encontramos, cerambicideos imitando vespas, borboletas imitando Bombus, gafanhotos imitando folhas, uma espécie de Apiomerus (1) imitando operárias de Melipona quadrifasciata LEP., com mais frequência deveremos encontrar abelhas sem ferão imitando as que o tem bem desenvolvido. Uma idéia de quanto um tal sistema deverá proteger os Meliponini temos na seguinte experiência, citada por Poulton (1933, pg. 103) : "Uma operária de Apis mellifera LINNAEUS fói libertada numa gaiola que continha um cameleão, o qual logo começou a observála, e, assim que esta ficou parada, capturou-a com sua língua. Assim que a língua foi sendo retirada com a abelha aderente na extremidade, o cameleão foi picado e imediatamente mostrou sinais de desconforto, tendo lançado fora a abelha. Muitos meses após êsse fato, foram colocadas abelhas nessa gaiola, a

(1) Sendo frequentemente encontrado na porta das colónias de Melipona quadrifasciata LEP. para aprisionar suas operárias. 
intervalos regulares, porém, a educação do cameleão, nesse sentido, foi completa, e nenhuma outra abelha foi tocada. Essa experiência nos mostra quanta utilidade será para os Meliponini um mimetismo com espécies com ferrão bem desenvolvido.

Ainda sôbre o assunto de predação queriamos mencionar algumas espécies que possuem grande propensão ao saque (2) como as espécies do gênero Lestrimelitta e mais as Trigona (Trigona) hialinata LEP., Trigona (Trigona) ruficrus LAT., Trigona (Trigona) amalthea OLIVIER, Trigona (Scaptotrigona)pectoralis DALLA TORRE, etc., e também, menos comumente, Melipona quadrifasciata LEP. e Trigona (Tretragonisca) jaty F. SMITH. Com exceção das espécies de Lestrimelitta que, apesar de poderem executar as tarefas de armazenar alimentos, são especializadas para o saque, as demais praticam o saque sòmente quando há escassez de alimentos ou quando há uma colónia fraca demais que lhes favorece a oportunidade; sempre, nesses casos, há uma grande mortalidade de ambos os lados. Nos saques praticados pelas espécies do gênero Lestrimelitta é interessante notar que há muito poucos mortos de ambos os lados. As Lestrimelittas praticam o saque comumente, usando, para isso, um processo que tivemos a oportunidade de, pelo menos em parte, desvendar. Estávamos fazendo uma revisão nas nossas colónias, quando notámos um grande reboliço na colónia número 8 de $M$. quadrifasciata anthidioides LEP. Quando chegámos a 1,50ms. aproximadamente, da dita colónia, sentimos um forte cheiro de limão, característico da espécie Lestrimelitta limão F. SMITH que possuíamos. Abrimos a colméia e verificámos que duas operárias de L. limão F. SMITH haviam burlado a vigilância dos vigias de $M$. quadrifasciata LEP. e estavam no interior da colónia, onde se notava mais fortemente

(2) Chamamos de 'saque', aquí, à pilhagem executada por um grande número de abelhas com visível prejuizo para as reservas e muitas vezes para a sobrevivência da colónia pilhada. Não tratamos, aquí, do roubo ocasional executado por poucas abelhas e que pouco dano faz a colónia. Tanto o primeiro coma segundo casos foram muito bem estudados numa publicação recente de Nogueira Netto (1949). 
o cheiro de limão. No mesmo dia, à tarde, essa colméia foi saqueada por grande número de operárias, tendo havido pouquíssimas mortes, ao contrário do que acontece com as demais espécies saqueantes (1). Daí, deduzimos que o que se passa é o seguinte : preliminarmente algumas operárias de Lestrilitta limão F. SMITH entram na colméia escolhida para o saque e secrétam um líquido que faz a colméia ficar com o cheiro forte de limão. Como é sabido, as operárias vigias vetam a entrada aos indivíduos que não possuam o cheiro da colméia; assim, após estarem tôdas impregnadas com cheiro de limão, é fácil às operárias de Lestrimelitta entrarem e saquearem.

Entretanto, observámos, em uma colónia de Trigona (Nannotrigona) testaceicornis LEP., saqueada por Lestrimelitta, que tôdas as operárias adultas, da primeira, ficaram esvoaçando do lado de fora, mantidas a distância por umas 20 operárias de Lestrimelitta. Essa observação foi por diversas vezes feita por Michener (1946) e com a mesma espécie Trigona (Nannotrigona) testaceicornis LEP. A atuação das operárias dessa espécie, que não hesitariam em atacar um inimigo maior, nos leva a crer que o cheiro dasLestrimelittas talvez lhes atue como um forte repelente.

\section{CONSIDERAÇõES GERAIS}

\section{3a. Parte}

Foram discutidos nesta tese, em sua primeira parte, alguns princípios da genética de populações em himenópteros arrenótocos. $\mathrm{Na} 2 \mathrm{a}$. parte demos certos dados biológicos que interessam a esta classe de estudos, e, finalmente, nesta última parte, queremos considerar algumas possibilidades evolutivas dos himenópteros e umas tantas observações esparsas que dizem respeito ao assunto de que tratámos.

A teoria moderna da evolução toma como ponto de partida a existência de mutações, sôbre as quais atua a seleção natural. Como acentua Brieger (1949), ser-nos-ia difícil explicar uma evolução filogenética, baseados sòmente em mutações aci-

(1) Recentemente, uma das nossas colónias de M. quadrifasciata anthidioides LEP. atacou outra da mesma subespécie, tendo perecido cêrca de 500 abelhas. Essa mesma colónia atacante saqueou e destruiu uma colónia de M. favosa orbignyi GUéRIN, tendo perecido tantas de suas operárias quantas eram as operárias adultas de M. favosa orbignyi GUéRIN. 
dentais e não dirígidas. Porém, essa situação muda-se, se supusermos que as mutações se acumulam gradativamente, formando uma "reserva gênica", sôbre a qual a seleção natural age em dadas circunstâncias, como, por exemplo, quando houver mudanças do meio exterior, como variações do clima, ou interior, devido a alguma nova mutação. Essa reserva gênica determina, portanto, uma plasticidade genética, que é de extrema importância para a especiação, devido a favorecer o aparecimento de indivíduos adaptados a maior número de condições ecológicas, e favorecer, também, a sobrevivência da espécie, quando se mudarem bruscamente as condições ambientes do momento. Brieger (1949) acha que a seleção, atuando sôbre a reserva gênica, em determinadas condições, não só tem a função de eliminar ou favorecer determinados gens, mas também póde provocar, como efeito indireto, mudanças na interação dos gens; tal processo foi por Brieger denominado "modifier shift".

Outro mecanismo cujo valor vem ganhando terreno dia a dia nos estudos de genética de populações, devido ao fato de estar se tornando patente a sua grande importância é a "oscilação genética", que modifica profundamente as possibilidades evolutivas das espécies pouco numerosas; como êste é o caso de alguns himenópteros sociais, trataremos, também, dêste assunto, aquí.

Em primeiro lugar, teceremos considerações sôbre a "plasticidade genética", por ser um assunto de que possuimos mais dados.

\section{I - PLASTICIDADE GENETICA}

Entendemos por plasticidade genética a capacidade de uma determinada população ou espécie poder reagir prontamente a variações do meio ambiente por mudanças no equilíbrio de seus diversos genotipos. Uma das exigências básicas para haver tal plasticidade genética é a existência de diversos genotipos diferentes.

Pensou-se, por muito tempo, que os Hymenoptera deviam possuir populações extremamente homogêneas devido ao seu mecanismo haplodiploide, visto com quaisquer mutações subviáveis ou letais nas atuais condições mesológicas seriam eliminadas, não contribuindo; portanto, para a plasticidade do grupo. 
Podemos, no entanto, assinalar para os Hymenoptera alguns mecanismos que podem favorecer tal plasticidade, que são : 1) variações citológicas e 2) reserva gênica.

\section{a) Variações citológicas}

Temos que considerar dois tipos de variações citológicas: a) numéricas (poliploidia e polisomia) e b) duplicações.

\section{1 - POLIPLÓIDIA E POLISOMIA}

Nos Hymenoptera, a mudança para um sistema diplo-tetraplóide, ao invés de haplodiplóide, impedirá o desaparecimen'to imediato dos recessivos letais ou subviáveis. Esse mecanismo parece existir em diversos grupos dos Hymenoptera como em Diprion, estudado por Smith (1941) onde as espécies $D$. polytomum ATG. (canadense), D. abieticolor, D.T., D. pallidum, KL.,D. nemorum F. VON GMEL, Neodiprion sertifer GEOFFR, possuem 7 cromossômas (n) ao passo que a espécie Diprion simile ATG. possui $\mathrm{n}=14$ cromossômas.

Em Apis mellifera L., foi relatado por diversos autores (Nachtsheim 1913, Manning 1948, 1949) um pareamento secundário na profase II da meiose, no macho, sugerindo uma possível origem tetraplóide. Esse pareamento secundário, é, entretanto, negado por Sanderson e Hall (1948), mas, em lâminas que fizemos para verificação do assunto, constatámos a exatidão das seguintes observações de Manning (1948) : pareamento secundário e existência de um cromossôma sexual que é expulso na II divisão meiótica do macho.

Também, o fato de um grupo de abelhas da mesma sub-família Apinae, o gênero Melipona, possuir um número haploide de 9 cromossômas (Kerr, 1948), que é, aproximadamente, a metade do número de cromossômas de Apis $\mathrm{n}=16$ ), sugere a provável origem dêste último, de um estoque primitivo com $\mathrm{n}=\mathbf{8}$ cromossômas por poliploidia $(\mathrm{n}+\mathrm{n})$ e do gênero Melipona por polisomia $(n+1)$.

Pensamos que a origem do cromossôma sexual em Apis seja ligada as complicações impostas pela diplo-tetraploidia. $\mathrm{Na}$ fase haplodiplóide a espécie possuia o mecanismo comum pelo qual os indivíduos haplóides seriam machos e os diplóides, fêmeas. Ao dar-se a poliploidia, aquêle equilíbrio foi quebrado, e os indivíduos com 16 cromossômas, que antes eram fêmeas, agora deverão ser machos. Como se sabe, há gens para sexualidade nos cromossômas de himenópteros (Whiting 1940). Pode, 
então, ter-se processado uma seleção em que um dos cromossômas, que possuia gens para sexualidade, transformou-se em um cromossôma do sexo. Como analogia, podemos nos referir aos estudos de Winge (1934) em Lepistes reticulatus onde houve, também, mudanças no equilíbrio gênico, de modo que um outosoma pode transformar-se em cromossoma sexual. Segundo Manning (1948) as fêmeas de Apis têm 31 cromossômas $(30+\mathrm{X})$ e os machos, 16 cromossômas $(15+\mathrm{X})$. Assim, devido à diplotetraploidia o seu mecanismo determinador do sexo voltou a ser da mesma ordem que em muitos outros insetos diplóides, isto é na base de balanço gênico, em que o cromossôma X conteria gens masculinizantes e os autosomas gens feminizantes sendo que

$$
\frac{\mathrm{X}}{\mathbf{2}}=\text { o } \mathrm{e} \frac{\mathrm{X}}{\mathrm{A}}=\sigma^{x} \text {. }
$$

Assim, o acréscimo do mecanismo gênico, ligado ao aparecimento do cromossôma sexual, permitiu às Apis manterem seu sistema partenogenético, com as vantagens adaptativas que tal sistema já lhes havia conferido. Conhecemos dois outros exemplos de cromossômas do sexo, em himenópteros: um é em Telenomus jariai LIMA estudado por Dreyfus e Breuer (1944) e outro é o do Pteromalus puparum, estudado por Dozorceva (1936). E' interessante notar que nesses dois himenópteros o número haplóide de cromossômas é 10 , que é superior ao número da maioria dos microhimenópteros conhecidos, que varia entre 4 e 8 cromossômas.

\section{2 - DUPLICAÇÕES}

Este processo é sugeridó por White $(1945$, pg. 279) da seguinte maneira : “ $E$ ', certamente, possível que os genomas dos Hymenoptera contenham duplicações, numerosas e grandes, podendo, neste caso, existir um reservatório de variabilidade escondida, com respeito a todos os loci situados nas regióes duplicadas (que poderiam ser presentes em dose dupla nos machos e quadrupla nas fêmeas)". Concordamos com White na possibilidade dêsse mecanismo, porém, não conhecemos dados que provem sua existência entre os himenópteros.

\section{b) Reserva Gênica}

A reserva gênica de uma população compõe-se de tôdas as mutações que ocorreram e que são acumuladas e conservadas por diversos mecanismos. As mutações, tanto gênicas, cromo- 
sômicas, como citoplasmáticas, podem ser classificadas, de acôrdo com seu efeito sôbre a sobrevivência, nas seguintes categorias (1) :

1) subviáveis

2) superviáveis

3) de isolamento

4) neutras

5) heteróticas

Estudaremos qual o comportamento de cada uma, e suas possibilidades para o aumento da reserva gênica :

1) As mutações subviáveis (não heteróticas) só poderão ser mantidas e acumuladas em uma população pela pressão de novas mutações ou de constantes migrações. Existem, ainda, muito poucos casos de mutações dêste tipo estudados em abelhas, sendo um dos poucos o do gen para ôlho branco, em Apis mellifera L., que atrapalha sèriamente a visão dos indivíduos que o possuem em dupla dose (Mikhaillof 1931, Nolan 1937).

2) Os gens superviáveis, por pequena que seja sua frequência inicial, substituirão o alele primitivo em um número de gerações tanto menor quanto maior for seu valor de sobrevivência. A única possibilidade de gens dêste tipo serem eliminados antes de poderem substituir' seu alele é a das populações pequenas, devido ao efeito da oscilação genética.

Forçosamente, uma grande maioria dos gens de uma população pertencem a êste tipo, porém, êstes gens não contribuem para a "reserva gênica", mas sim para os gens que se estão manifestando imediatamente; a contribuição para a plasticidade genética dos mutantes dêste tipo depende exclusivamente das suas propriedades fisiológicas particulares.

Tanto para as mutações para gens subviáveis como para superviáveis, a situação para os fatores limitados ao sexo feminino é a mesma já descrita, sòmente variando o número de gerações com que alcançarão o equilíbrio final. Para os mutantes limitados ao sexo masculino teremos que o gen menos viável só poderá ser mantido por fôrça de novas mutações. Também serão mantidos os gens dessa natureza quando ambos os genotipos possuirem índices de sobrevivência iguais, porém, tal situação dificilmente poderá acontecer na natureza.

(1) Queremos lembrar que não importa, nesta classificação, que os gens sejam dominantes, intermediários ou recessivos, mas o que interessa são os seus efeitos sôbre a sobrevivência. 
3) Os mutantes de isolamento são os que determinam qualquer modificação no indivíduo de maneira que os híbridos possuam menor valor de sobrevivência. Em uma população grande, tais gens poderão permanecer pela pressão de novas mutações, quer sejam menos ou mais viáveis que o alele primitivo; porém, em populações pequenas e isoladas, o gen mais viável tem possibilidades de suplantar o seu alele. Não temos dados sôbre a frequência ou existência de mutantes desta natureza entre os Hymenoptera, porém, seguramente, muito pouco contribuirâo para a plasticidade genética de uma determinada população.

4) Os gens neutros constituem uma grande fonte de variabilidade, dando às populações que o possuem em grande número uma grande plasticidade. Essas plasticidade é oriunda do fato de um par de aléles poder ser neutro nas atuais condições mesológicas, mas, mudando-se estas, ambos os aleles não tomarão valores proporcionais, porém, terão adaptabilidades diferentes. Em Drosophila pseudoobscura FROLOVA é conhecido o caso de que certos tipos de inversões, entre $15^{\circ}$. e $16^{\circ} \mathrm{C}$, são praticamente neutras; porém, a $25^{\circ} \mathrm{C}$ os heterozigotos são muito mais viáveis (Dobzhansky 1948). EmApis mellifera L. já foram notados alguns caracteres, como, por exemplo, a banda amarela do abdómen, característica da raça italiana ( $A$. mellifera lestritica SPINOLA), que, em algumas zonas, dá maior adaptabilidade às abelhas que a possuem; noutras, tais caracteres são neutros, enquanto que noutras regiões parecem ser contra-indicados, como se deduz de uma discussão de apicultores norte-americanos (Thompson 1948, Editor do "Gleanings in Bee Culture 1948, Abushady 1948). Diversos apicultores do Estado de São Paulo e do Estado do Rio de Janeiro verificaram, para êsse carácter "banda amarela", que as rainhas amarelas têm melhor postura e as operárias amarelas são mais trabalhadeiras, chegando, em algumas localidades, a enfraquecer vitalmente as colónias de abelhas pretas, devido à desiquilibrada competição que estabelecem. Porém, as rainhas pretas são mais "zanganeiras", isto é, produzem maior número de machos, e êstes parecem ser mais ativos que os machos amarelos, de maneira que, na época da enxameagem, as rainhas amarelas têm maiores probabilidades de ser fecundadas por machos pretos. E' um caso interessante em que um mesmo fator confere propriedades de sobrevivência antagônicas, conforme se trate do sexo masculino ou feminino. 
Outros gens, como os que determinam a côr do escutelo (Munro 1925) e a côr do clípeo,genae e labro (Nolan, 1937), parecem, também, ser neutros.

5) Os gens heteróticos, principalmente nas espécies com cruzamento livre, constituem um dos fatores que ampliam a plastieidade genética, originando, por seu acúmulo, juntamente com os gens neutros, as espécies polimorfas.

Os gens neutros alcaçam seu equilíbrio numa população pela equação:

$$
\frac{p}{q}=\frac{u}{v}
$$

onde $p$ é a frequência do gen (A), $q$ a frequência de (a), $u$ a taxa de mutação de (A) para (a) e $v$ a taxa de mutação de (a) para (A).

Os dois pontos mais importantes, que nos são revelados pelo estudo de modêlos matemáticos em populações em himenopteros, são : primeiro, aquêle que nos demonstra a possibilidade de existirem em equilíbrio nas suas populações, sem a pressão de novas mutações, gens subviáveis e mesmo letais, desde que possuam efeito heterótico dentro de certos limites (pg. 15) e, segundo, a demonstração de que os gens limitados ao sexo feminino se comportam como se fossem em populações diploides (pg. 16).

Quando encontramos, em uma população, mais de um alele, podemos dizer que, na quase totalidade dos casos, estamos diante de gens heteróticos ou neutros.

Os esquemas matemáticos apresentam-nos, para os gens heteróticos, êstes dois caminhos.

A) Gens heteróticos, cujos efeitos afetam tanto as fêmeas como os machos; assunto de que trataremos logo abaixo; e

B) Gens heteróticos limitados ao sexo feminino, isto é, quando as fêmeas homozigotas são inferiores às heterozigotas, porém, os machos não são afetados (pg. 75).

\section{A - Gens heteróticos não limitados a um dos sexos}

A única prova experimental que conhecemos, demonstrando a existência de gens heteróticos em Apis mellifera L., é dada pelas experiências de Mackensen e colaboradores (Farrar, 
1947, 1948), que obtiveram diversas gerações de rainhas fecundadas por seus próprios filhos, que, como foi demonstrado matematicamente por Kalmus e Smith (1948), é o método que leva à homozigotia mais ràpidamente. $O$ resultado dêsse endocruzamento foi uma rápida perda de vigor das colónias assim originadas, e uma grande porcentagem de ovos gorados.

O intercruzamento das linhagens puras deu, ao contrário, um grande vigor; algumas das colónias duplo-híbridas foram, mesmo, excepcionalmente produtivas, porém, intoleravelmente viciosas. Até mesmo esta última qualidade pode ser interpretada como uma manifestação da heterose, porém, o vigor e produção das colónias duplo-hibridas é uma prova iniludível do grande número de gens heteróticos existentes nas populações de Apis mellifera L.

Os gens heteróticos não limitados às fêmeas afetam muito mais os machos que as fêmeas, pelo motivo já exposto de os primeiros comportarem-se como homozigotos para todos os fatores, e, portanto, se a existência de gens heteróticos é exata, devemos obter: 1) uma maior variabilidade nos machos que nas fêmeas e 2) uma maior porcentagem, entre os machos, de indivíduos subviáveis e indesejáveis.

1) A primeira hipótese pode ser confirmada pelas observações em Apis mellifera L. feitas por Casteel e Phillips (1903) em seu trabalho: "Comparative variability of drones and workers of the honey bee", e também confirmado, posteriormente, por outros investigadores (Stucki, 1936; Nolan 1937).

Casteel e Phillips tomaram como base, em seus trabalhos, as veias e células das asas. Calcularemos, aquí, como exemplo, o o 1

teste de teta $(\underset{\sigma 2}{-})$ para alguns dos dados de Casteel e Phillips retirados sòmente dos machos que, em seu trabalho, pertencem ao lote $\mathrm{V}$, e das fêmeas do lote I, por serem oriundos da mesma colméia, portanto, da mesma raça, (italiana), fator importante para a exatidão da análise. Para verificação da nomenclatura, veja-se figura 60 . O número de indivíduos, em todos os quadros IV a VIII é de 50 . 
QUADRO IV

Comprimento da veia $R$ (Taboa I de C. e P.)

\begin{tabular}{l|c|c|c}
\hline \multicolumn{1}{c|}{ Casta } & Média & Erro Standard & teta \\
\hline Zangão & 36,92 & 2,271 & \\
\hline Operária & 37,46 & 1,606 & 1,414 \\
\hline
\end{tabular}

QUADRO V

\begin{tabular}{c|c|c|c}
\hline \multicolumn{2}{c|}{ Diagonal da célula R4 (Taboa II de C. e P.) } & \multirow{2}{*}{ teta } \\
\hline Casta & Média & Erro Standard & teta \\
\hline Zangão & 101,98 & 3,730 & \\
\hline Operária & 76,36 & 2,362 & 1,579 \\
\hline
\end{tabular}

QUADRO VI

\begin{tabular}{l|c|c|c}
\hline \multicolumn{2}{c|}{ Comprimento da veia M2 (Taboa III de C. e P.) } & \\
\hline \multicolumn{1}{c|}{ Casta } & Média & Erro Standard & teta \\
\hline Zangão & 46,96 & 2,531 & \\
\hline Operária & 33,82 & 1,187 & 2,132 \\
\hline
\end{tabular}

\section{QUADRO VII}

Comprimento da veia $\mathrm{m}$ (Taboa IV de C. e P.)

\begin{tabular}{c|c|c|c} 
Casta & Média & Erro Standard & teta \\
\hline Zangão & 97,08 & 3,129 & \\
\hline Operária & 72,30 & 2,141 & 1,461 \\
\hline
\end{tabular}




\section{QUADRO VIII}

\begin{tabular}{l|c|c|c}
\hline \multicolumn{1}{c|}{ Hâmulos nas asas traseiras (T. VII de C. e P.) } & \multirow{2}{*}{ teta } \\
\hline Casta & Média & Erro Standard & teta \\
Zangão & 21,54 & 2,140 & \\
Operária & $\mathbf{2 1 , 4 2}$ & 1,565 & 1,367 \\
\hline
\end{tabular}

Limites de teta para $(\mathrm{nf} 1=49, \mathrm{nf} 2=49)$ segundo Brieger 1946, Taboa II d :

$$
\begin{array}{r}
5 \%=1,27 \\
1 \%=1,39 \\
0,1 \%=1,56
\end{array}
$$

Nota : As medidas apresentadas nos Quadros IV, V, VI e VII para médias e êrro standard foram dadas em decimilimetros.

Podemos verificar que, dos 5 quocientes de êrros dos quadros IV a VIII, um tem valor superior ao limite de probabilidade de $1 \%$ o, 3 estão entre os limites de $1 \%$ e $1 \%$ o, e o último, entre os limites de $5 \%$ e $1 \%$, concluindo, seguramente, os êrros referentes aos machos tendem sempre a ser maiores que os das operárias, o que significa que, realmente, os machos são mais variáveis que as fêmeas em Apis mellifera $\mathrm{L}$..

Essa mesma maior variação entre machos e fêmeas verificámos, também, nas duas outras tribus dos Apinae sociais : Bombini e Melipinini.

Medimos o comprimento da língua dos machos e fêmeas de Bombus rubicundus F. SMITH, e, apesar do diminuto número de exemplares de que pudemos dispôr, verificámos que o êrro "standard" para os machos era 0,77, e, para as fêmeas, 0,06 (Quadro X). Fazendo um teste de teta, achámos um valor 12,83, valor êste altamente significativo, demonstrando, novamente, a maior variabilidade dos machos de Bombus.

Para os Meliponini, fizemos medições em M. quadrifasciata LEP., (Quadro IX) também para o comprimento da língua, que, além de ser um órgão importantíssimo para a subsistên- 
cia da espécie, é muito pouco variável (1); verificámos que o teta, entre os êrros dos machos e das operárias, é 2,345; portanto, os machos são, positivamente, mais variáveis que as operárias.

No subgênero Paratrigona SCHWARZ, verifica-se (vêr Schwarz, 1948, figuras 57, 58, 63, 64, 65 e textos correspondentes) a grande diferença que há entre os machos de suas diversas espécies enquanto que nas rainhas e operárias as diferenças de uma espécie para outra estão em uma escala muito menor. No subgênero Trigona JURINE observa-se essa mesma desproporção entre a variabilidade nos caractéres dos machos e a nos caractéres das fêmeas, se bem que menos pronunciada que no subgenero Paratrigona SHAWARZ.

(1) Podiámos utilizar para verificar as variações, das pesagens das abelhas, ao invés de usar nos o comprimento da língua, porém, não o fizemos devido ao fato de os pesos serem mais variáveis que o comprimento das línguas. Verificámos isso pelo coeficiente de variação. Êsse coeficiente é, para os pesos das abelhas, de, aproximadamente, 2 a 4 vezes maior que para o comprimento das línguas das mesmas abelhas, como podemos verificar pelos seguintes dados das colónias 35 e 8 .

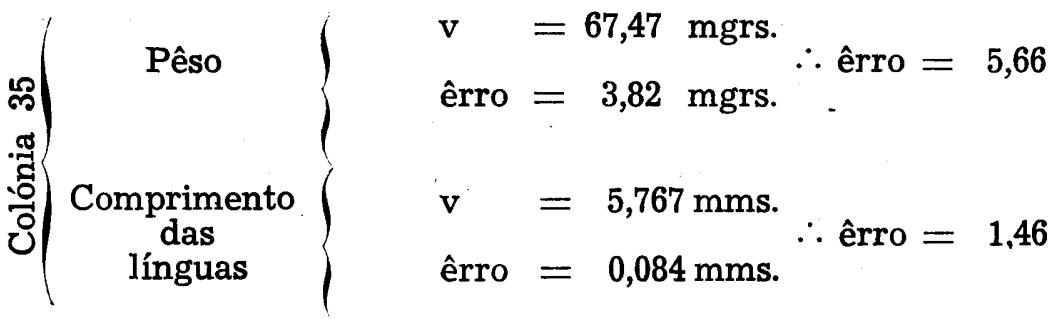

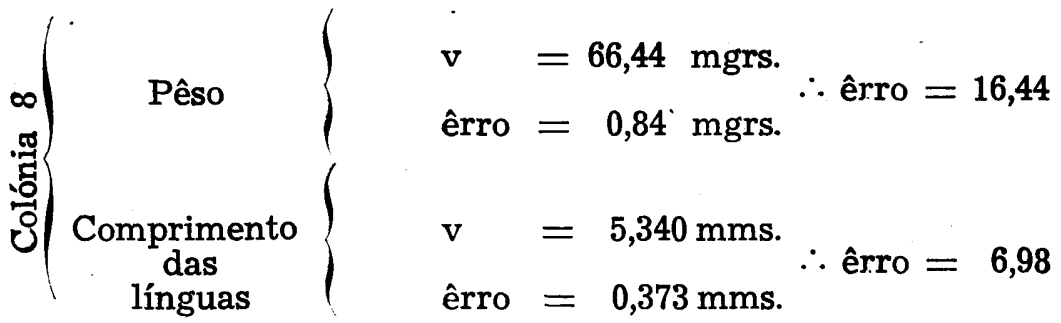

Não podemos, neste caso, aplicar um teste rigoroso, como entre os indices de variança (Brieger, 1942), devido ao fato de nossas variáveis peso e comprimento de língua, serem tomadas em unidades diferentes, uma, em mgrs. e outra em mms. 
No final do trabalho de Casteel e Phillips (o. c.) êstes dão como causa próvável da variação maior verificada nos machos a maior variabilidade no tamanho das suas células. Porém, isso não explica a maior variabilidade entre os machos dosBombini e Apini. Por isso, achamos que essa maior variabilidade deve ser produzida por fatores quantitativos, com efeito dominante, heterótico e epistático. Assim sendo, o número de fenotipos nos machos será igual ao número de genotipos segregados pelo rainha, ao passo que as operárias terão redução de fenotipos devido aos motivos apontados supra.

2) Pensamos poder demonstrar a existência de gens que diminuem a viabilidade, tanto nos machos como nas fêmeas, com as três observações seguintes, duas, nossas, e uma, de Casteel e Phillips (o. c.) :

a) Verificámos que, ao emergirem, existem machos de diversos tamanhos, alguns, extremamente pequenos, dando, mesmo para a língua, (veja-se rodapé da página anterior), uma variação relativamente grande (Quadro IX) ; porém, se medirmos sòmente machos adultos, a variação ficará, aproximadamente, da mesma ordem que a das operárias (Quadro XI). Isso demonstra que há machos deficientes que são eliminados. Podemos dizer que, se não houvesse heterose, com uma eliminação tão forte, em poucas gerações, a espécie estaria pura.

b) Verificámos certa mortalidade entre prepupas de $M$. quadrifasciata LEP. (colónia 40-b), pois, em 102 machos, encontrámos 7 indivíduos mortos na fase larval e um na fase prepupal. Atribuimos êsse efeito à combinação de gens subviáveis, que, devido a quaisquer condições mesológicas não permitiram aos indivíduos sobreviverem. Nessas mesmas condições não houve falhas na zona do favo em que havia operárias e rainhas (os ovos que deverão originar machos são postos preferencialmente no centro dos favos).

c) As observações de Casteel e Phillips sôbre asas anormais resumem-se no seguinte : encontraram, em 500 machos e 500 operárias analisados, 206 machos possuidores de anormalidades nas asas ao passo que sòmente encontraram 30 operárias com defeitos alares, dando, para os machos, 7 vezes mais anormalidades que para as operárias.

Antes de concluir, queremos deixar a seguinte sugestão, que baseámos nos dados que daremos abaixo. Se um grupo, família ou espécie for adquirindo, para a sua evolução, cada vez mais gens heteróticos (não limitados às fêmeas) teremos que os machos, por serem sempre puros para os fatores em questão, sofrerão cada vez mais com a evolução da espécie. Como um 
exemplo rudimentar dêsse caso poderiamos citar o gênero mais evoluido dos Apinae, gênero Apis, onde o macho perdeu completamente a capacidade de secretar cêra, que ainda existe entre os Meliponini (1) : também o comprimento de sua língua, órgão vital para a autosubsistência das abelhas, quando comparado relativamente às operárias, é muito inferior ao das tribus vizinhas, como podemos concluir do seguinte quadro:

QUADRO IX - A

\begin{tabular}{|c|c|c|c|c|}
\hline & $\begin{array}{c}\text { Compr. } \\
\text { língua } \\
\delta\end{array}$ & $\begin{array}{l}\text { Compr. } \\
\text { língua } \\
\text { † }\end{array}$ & Rel. $\frac{T}{0}$ & Referências \\
\hline $\begin{array}{l}\overline{\text { Bombus rubicundus }} \\
\text { SMITH }\end{array}$ & 6,84mms. & $7,60 \mathrm{mms}$. & 1,11 & Quadro X \\
\hline $\begin{array}{l}\text { Melipona marginato } \\
\text { LEP. } \\
\text { Melipona quadrifas- }\end{array}$ & $3,55 \mathrm{mms}$. & $3,87 \mathrm{mms}$. & 1,09 & Quadro XI \\
\hline $\begin{array}{l}\text { Apiata LEP. } \\
\text { Aplifera LIN- }\end{array}$ & $5,17 \mathrm{mms}$ & $5,95 \mathrm{mms}$ & 1,15 & Quadro IX \\
\hline & $3,59 \mathrm{mms}$. & $6,55 \mathrm{mms}$. & 1,82 & Alpatov, \\
\hline
\end{tabular}

O acúmulo progressivo de gens heteróticos poderá, como supusemos para Apis melliferd L., ir degradando progressivamente a classe haploide. Para comprovar esta sugestão, necessitamos de examinar colónia de rainhas cruzadas com seus próprios filhos para verificar se há diminuição da capacidade de produzir cêra e se há diminuição no comprimento da língua conforme aumente a consanguinidade.

B) Gens heteróticos limitados às fêmeas

Antes de discutirmos os gens heteróticos, queremos fazer umas considerações de ordem geral sôbrè os gens de qualquer tipo, limitados ao sexo feminino.

White (1945) sugere que os gens recessivos limitados às fêmeas devem ser muito importantes para os Hymenoptera, pois tais mutantes, mesmo deletérios, poderão permanécer dentro das populações.

Pelo que sabemos por esquemas matemáticos, tais mutações deletérias 'não aumentarão a sua frequência, e șòmente se

(1) Schwarz (1948) põe em dúvida as observações de Drory (1873, 1874 e 1877) em M. marginata LEP. e M. scutelaris LAT. com relação à secreção de cêra pelos machos; porém, tivemos ocasião de observar em M. marginata LEP. e T. (Plebeia) mosquito F. SMITH, mais de uma centena de machos em franca secreção de cêra, confirmando, assim, as observações de Drory. 
manterão nas populações por fôrça de novas mutações. Porém, se tiverem efeito heterótico, seguirão o mesmo esquema das populações diplóides, isto é, tenderão para um limite bastante superior ao obtido ùnicamente por acúmulo de mutações.

Portanto, as mutações cujos gens possuam efeito heterótico, limitados os seus efeitos de maior ou menor viabilidade sòmente ao sexo feminino, poderão ser importantíssimos para os himenópteros, pois capacita-os a ter uma plasticidade genética igual à das populações diplóides com fecundação livre, como vimos à página 16 .

QUADRO IX

\begin{tabular}{|c|c|c|}
\hline \multicolumn{3}{|c|}{$\begin{array}{l}\text { Melipona quadrifasciata LEP. 40-B } \\
\text { Comprimento da língua (em mms.) }\end{array}$} \\
\hline Machos & Rainhas & Operárias \\
\hline $\begin{array}{l}\mathbf{5 , 5 5} \\
\mathbf{5 , 2 2} \\
\mathbf{4 , 8 5} \\
\mathbf{5 , 2 0} \\
\mathbf{4 , 9 2} \\
\mathbf{5 , 1 8} \\
\mathbf{5 , 5 3} \\
\mathbf{5 , 3 5} \\
\mathbf{5 , 3 4} \\
4,35 \\
\mathbf{5 , 0 4} \\
5,40 \\
\mathbf{4 , 9 0} \\
\mathbf{5 , 3 0} \\
\mathbf{5 , 5 1} \\
\mathbf{5 , 4 0} \\
\mathbf{5 , 1 0} \\
\mathbf{5 , 2 2} \\
\mathbf{5 , 5 8} \\
\mathbf{3 , 7 0} \\
\mathbf{5 , 5 5} \\
\mathbf{5 , 4 0} \\
\mathbf{5 , 0 9} \\
\mathbf{4 , 7 4} \\
\mathbf{5 , 3 3} \\
\mathbf{5 , 4 6} \\
\mathbf{5 , 3 3}\end{array}$ & $\begin{array}{l}3,90 \\
4,13 \\
4,23 \\
4,12 \\
4,10 \\
4,12 \\
4,10 \\
4,25 \\
4,25 \\
4,15 \\
4,00 \\
3,95 \\
4,00 \\
4,20 \\
4,12\end{array}$ & $\begin{array}{l}5,69 \\
6,05 \\
6,05 \\
5,95 \\
5,95 \\
6,20 \\
5,68 \\
6,10 \\
5,78 \\
6,02 \\
5,68 \\
6,00 \\
6,17 \\
6,01 \\
5,70 \\
6,15 \\
j, 95 \\
6,05\end{array}$ \\
\hline $\begin{array}{l}\text { média }=5,168 \\
\text { êrro }= \pm 0,4097\end{array}$ & $\begin{array}{l}\text { média }=4,107 \\
\text { êrro }= \pm 0,1527\end{array}$ & $\begin{array}{ll}\text { média }= & 5,954 \\
\text { êrro }= \pm & 0,1747\end{array}$ \\
\hline
\end{tabular}




$$
\text { teta }=\frac{0,4097}{0,1747}=2,34
$$

Limites segundo Brieger, 1946

$$
\begin{aligned}
& \mathrm{nf} 1=26 \\
& \mathrm{nf} 2=17
\end{aligned} \quad\left\{\begin{array}{l}
5 \%=1,49 \\
1 \%=1,74 \\
1 \% \mathrm{o}=2,15
\end{array}\right.
$$

\section{QUADRO X}

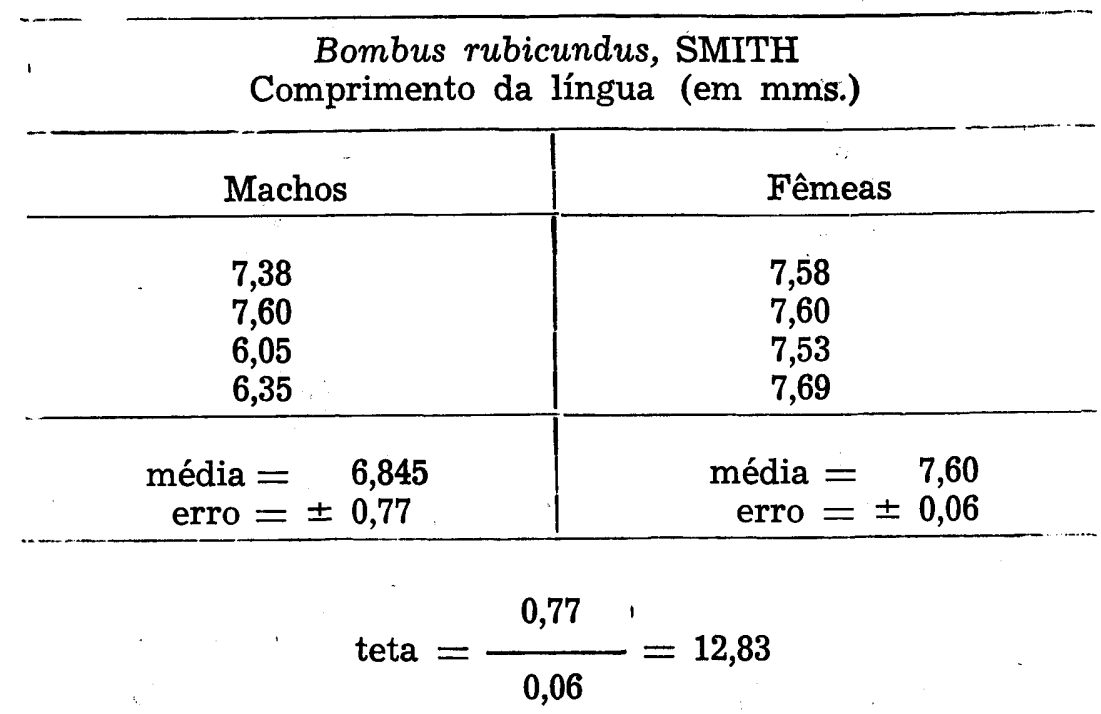

Limites segundo Brieger, 1946

$$
\begin{aligned}
& \mathrm{nf} 1=3 \\
& \mathrm{nf} 2=3
\end{aligned} \quad\left\{\begin{array}{l}
5 \%=3,05 \\
1 \%=5,43 \\
1 \% 0=11,9
\end{array}\right.
$$




\section{QUADRO XI}

Melipona marginata LEP.

Comprimento da língua (em mms.)

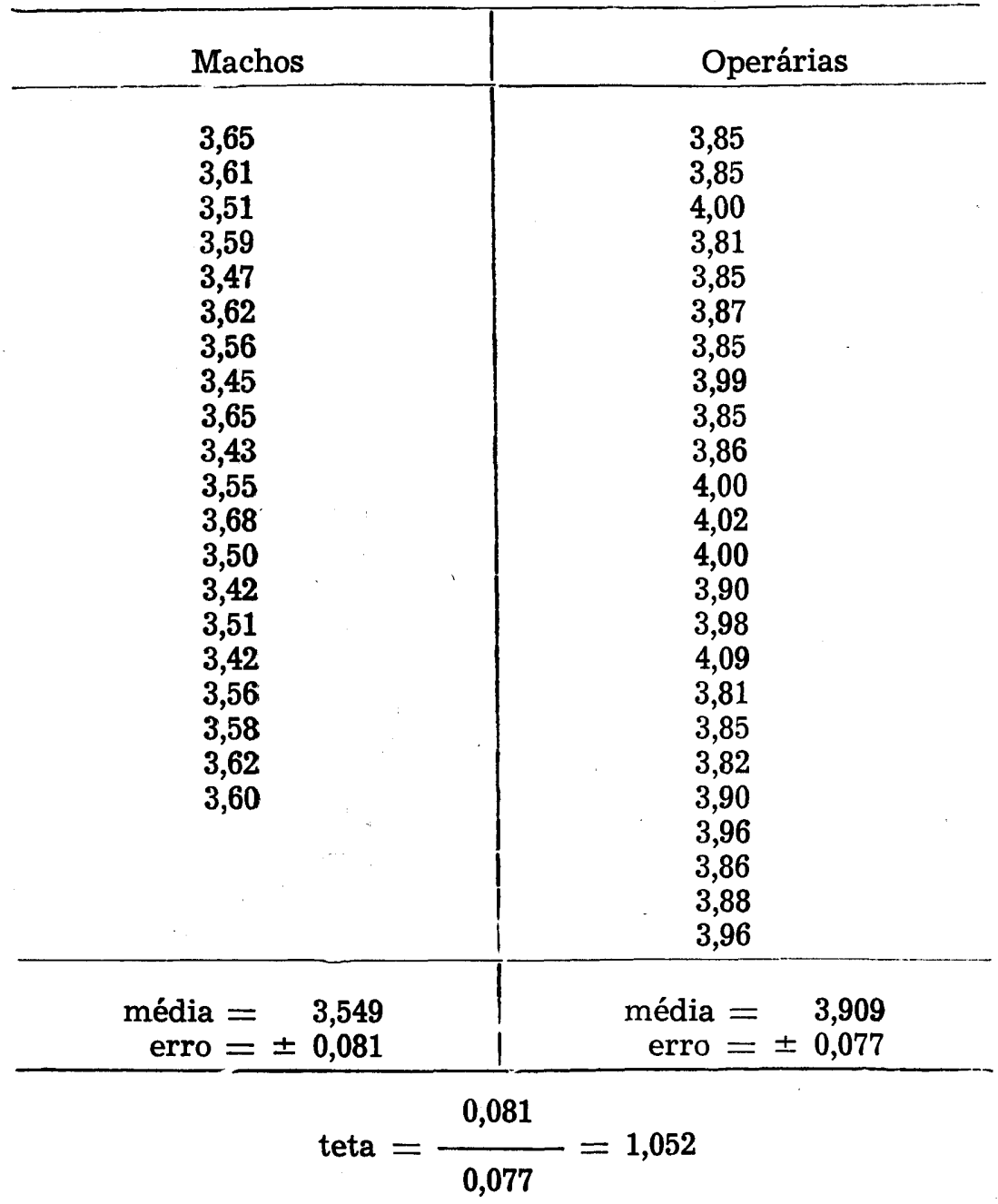

Limites segundo Brieger, 1946

$$
\begin{aligned}
& \text { nf1 }=19 \\
& \text { nf2 }=23
\end{aligned} \quad\left\{\begin{array}{l}
5 \%=1,45 \\
1 \%=1,69
\end{array}\right.
$$


Temos alguns exemplos de que os gens limitados ao sexo feminino contribuem grandemente para a plasticidade genética dos himenópteros sociais, como os seguintes :

E' fato sobejamente conhecido que as operárias de Apis mellifera $\mathrm{L}$. constroem células especiais para as rainhas e as alimentam com "geleia real" desde a eclosão do ovo até o fim da vida. Assim, a constituição genética da fêmea permite-lhe responder muito prontamente à variação alimentar, dando-lhe diferentes fenotipos, desde o de operária estéril, até o de rainha fértil, com diversos intermediários. Tal, porém, não acontece com os ovos não fecundados que, ocasionalmente, foram postos em "alvéolos reais". Raramente darão um zangão grande, sbem desenvolvido; o comum é dar um indivíduo raquítico, que pouca oportunidade terá de reproduzir-se.

O que dissemos aquí não invalida em nada a nossa demonstração de que os machos são mais variáveis. Em condições idênticas de alìmentação, os machos são mais variáveis que as fêmeas, porém, as fêmeas possuem maior plasticidade e são capazes de se adaptarem a diferentes condições alimentares.

Parece que casos idênticos dão-se com algumas formigas onde os machos são sempre de tamanho uniforme, enquanto que as fêmeas variam entre operárias miúdas, operárias poedeiras e rainhas.

Podemos, também, incluir, neste caso, as diversas espécies de Trigona e Lestrimelitta, onde a quantidade de alimento parece determinar a casta. Estes exemplos demonstram a existência de gens com efeitos limitados ao sexo feminino, dando a êsse sexo uma plasticidade muito grande em responder às diversas condições atimentares.

Não podemos dizer, entretanto, que nesses exemplos citados os gens sejam heteróticos, neutros, subviáveis ou de qualquer outro tipo; provavelmente, constituem um conjunto de todos os tipos. Porém, nos exemplos que citaremos abaixo, estamos diante de gens heteróticos limitados às fêmeas. São êles :

1) No gênero Melipona, onde as castas são determinadas genèticamente, (Kerr, 1946, 1947, 1948, 1950b), os fatores determinantes de casta são limitados ao sexo feminino. Assim, a homozigotia para um, dois ou três fatores darão origem a uma o- 
perária, enquanto que a dupla ou tripla heterozigotia, conforme se trate, respectivamente, da $M$. marginata LEP. ou das demais Meliponas, originará uma rainha. No entanto, os machos, por serem haplóides, comportam-se sempre como duplos ou triplos homozigotos para os fatores de casta, sendo, porém, férteis, comprovando a limitação ao sexo feminino da ação de tais fatores.

Estes fatores de casta são altamente heteróticos, pois os valores de sobrevivência reprodutivos dos homozigotos

(RAR e RaR) são iguais a zero, em virtude de serem estéreis as operárias homozigotas para qualquer dos três fatores. Assim, apesar de, individualmente, as operárias serem mais robustas que as rainhas e não dependerem de alimentação especial, o valor das primeiras, populacionalmente, é nulo, devido ao fato de não deixarem descendentes.

2) Como mais uma prova de que os gens limitados ao sexo, e, provavelmente, heteróticos (devida à alta frequência de colónias heterozigotas encontradas na natureza), são relativamente frequentes, citaremos dois gens encontrados em populações naturais de Meliponini.

a) Um gen, que chamaremos Dc (Dichromatico), determina a coloração amarelo-avermelhada em todo o abdómen das operárias de Trigona (Plebeia) mosquito F. SMITH, cuja segregação podemos observar no quadro XII. Seu aléle determina a coloração preta para o abdómen.

\section{QUADRO XII}

Trigona (Plebeia) mosquito F. SMITH - Colónia 92 Segregação na côr do abdómen das operárias

\begin{tabular}{c|c|c|c|c}
\hline Fenotipo & Observado & Esperaro & X2 teste & Signif. \\
\cline { 1 - 4 } Abdómen preto & 75 & 77 & 0,052 & \\
$\begin{array}{c}\text { Abdómen amarelo- } \\
\text { avermelhado }\end{array}$ & 79 & 77 & 0,052 & \\
Total & 154 & & 0,104 & Insignif. \\
\hline
\end{tabular}


Colocámos nesse quadro, sòmente os dados para as fêmeas, por serem todos os machos pretos. E', portanto, um gen limitado ao sexo feminino; assim, a nossa Colónia 7 apresenta dicromatismo sexual, tôdas as operárias possuindo abdómens amarelo-avermelhados, sendo todos os machos pretos (daí, a chamarmos de variedade dichromatica); nas colónias 24, 32 e 93, tanto as operárias como os machos são pretos (variedade unicolor); na colónia 92 as operárias apresentavam a segregação mostrada no quadro XII, devido ao caso de a rainha ser híbrida, fecundada por um macho recessivo, sendo, também, tanto os machos Dc como dc, de coloração preta.

b) Outro gen analisado foi em Melipona marginata LEP. e determina coloração amarelo-castanha nos segmentos medianos do inseto, isto é, na pata trazeira e no $2^{\circ}$. segmento abdominal (considerando-se, como $1^{\circ}$. segmento o propodeo); à̀s vezes, a coloração extende-se um pouco mais, alcançando todo o $3^{\circ}$. segmento e afetando um pouco a pata mediana. $O$ alele dêsse gen determina coloração preta para as partes citadas. Chamaremos o primeiro alele de $A m$ e o último de am; as suas segregações eñcontram-se no quadro-XIII.

Encontrámos, entretanto, nas nossas : colónias examinadas, duas classes de manifestações fenotípicas para os machos : uma, como, por exemplo, as colónias 78 e 77, em que os machos manifestam o efeito do gen do mesmo modo que as fêmeas, e outra, como as colónias 56 e 76 , em que só se percebe que o macho é $A m$ por observação na pata traseira, especialmente na tíbia. As colónias que exibem êsses fatores foram tôdas coletadas nas matas dos municípios de Santana de Parnaiba e São Roque.

Se se tratar de aleles múltiplos deveremos encontrar rainhas segregando $50 \%$ de um tipo e $50 \%$ de outro, entretanto, até agora, sòmente examinámos poucas colónias e não podemos decidir se é sòmente efeito de modificadores ou trata-se de um novo alele. Porém, de qualquer modo, ou sendo um novo alele, ou por possuir gens modificadores diferentes, o fato é que nas colónias 56 e 76, o efeito do gén $A m$ é quase totalmente limitado ao sexo feminino, sendo observado com dificuldade nos machos. 


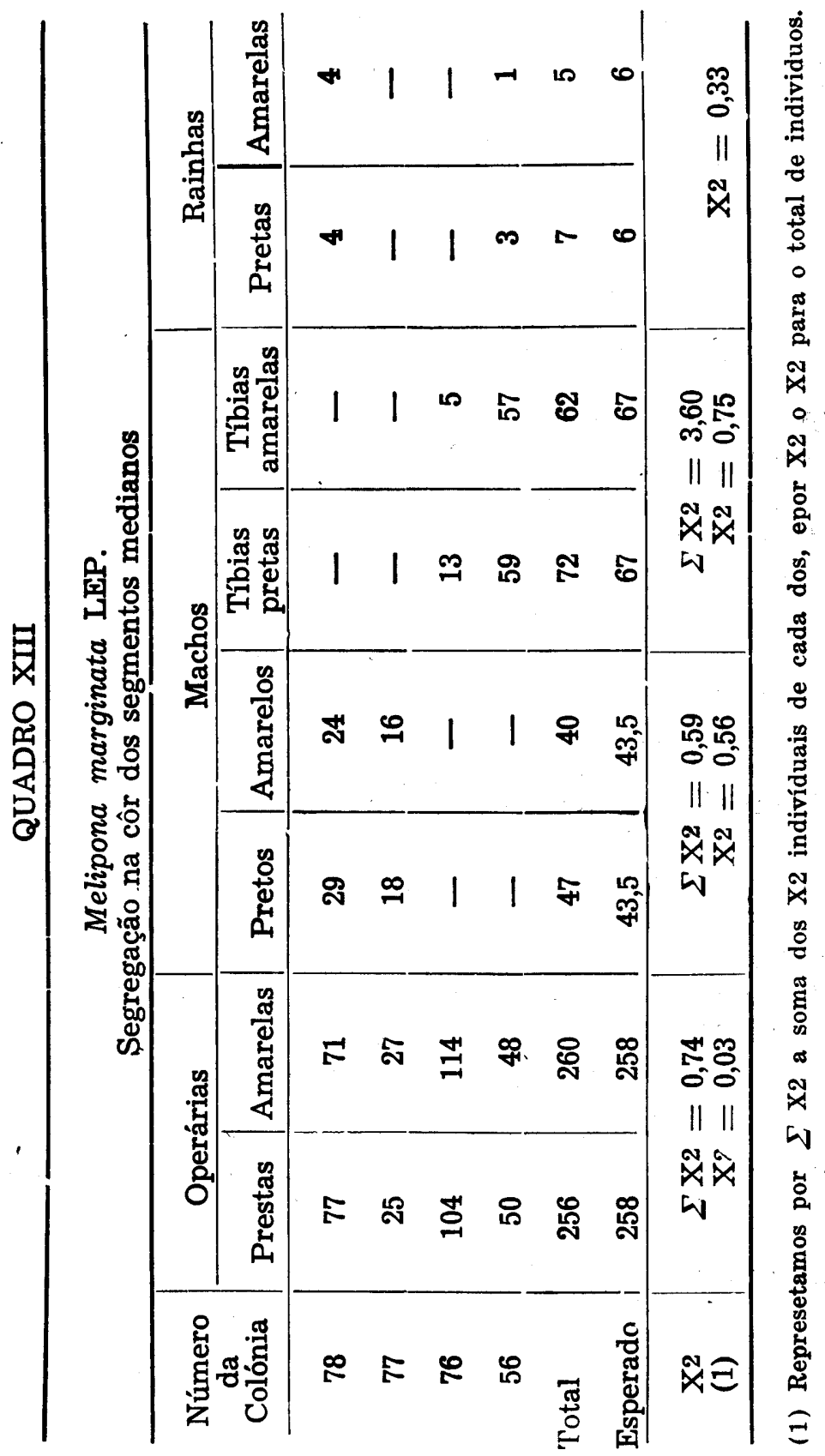


Verificámos, assim, a existência de fatores limitados ao se$\mathrm{xo}$, alguns dos quais nitidamente heteróticos. Os gens Dc e Am existem em porcentagens bem altas nas populações naturais de Trigona (Plebeia) mosquito F. SMITH e Melipona marginata LEP., respectivamente dos municípios de Piracicaba e Santana de Parnaiba e regiões circunvizinhas.

Essa frequência de heterozigotos, que no caso do gen $\mathrm{Am}$ é ao redor de $50 \%$ na região mencionada, é demasiadamente alta, podendo ser sómente explicada pela presença de gens heteróticos. Julgámos, entretanto, que o gen $A m$ deva ter valor heterótico sòmente nessa região, pois na região dos municípios de São José do Rio Pardo e Poços de Caldas encontrámos sòmente a forma preta.

\section{II - OSCILAÇÃO GENETICA}

Chama-se "oscilação genética" a mudança na frequência relativa de dois aleles, em uma população, devida ao acaso, portanto, diferente da mudança devida à seleção. As primeiras noções sôbre êsse assunto nos vêm de Brooks, porém, suas implicações genéticas só foram esclarecidas por Hagedoorn, Fischer, Dubinin, Romaschoff e, principalmente, Sewall Wrigth (literatura em Dobzhansky, 1941). O fator que leva a mudança da frequência relativa dos diversos aleles de uma população sem seleção é o número da população efetiva dentro da área de reprodução. Dobzhansky (1941, pg. 161-184) e Mayr (1947 pg. 234-236) reexaminaram diversos dados, para diversas espécies, verificando a grande importância do tamanho da população na evolução e especiação das mesmas.

Dubinin e Romoschoff (1932) e Brieger (1944) executaram modêlos interessantes para demonstrar a atuação da oscilação genética, os primeiros com diversas bolinhas representando diversos genotipos, e o último, com duas classes de cartas de baralho representando as frequências de dois aleles. Ambos demonstraram, com modêlos diferentes, que a atuação da oscilação genética é relativamente rápida.

Antes de fazermos um breve estudo sôbre o efeito da oscilação genética nos Apinae sociais queremos dizer que consideraremos, aquí, sòmente umas poucas espécies de Meliponini, deixando de estudar os Bombini por não termos quaisquer dados a respeito. Faremos também algumas considerações sôbre Apis melifera L. apezar de ser uma espécie domesticada, cuja densidade de população e cujos meios de distribuição se encontram artificialmente modificados. 
Resumindo o que foi tratado sôbre os Meliponini na segunda parte desta tese sob o título de "densidade de população", podemos dizer que as espécies mais frequêntes possuem uma densidade de população, aproximadamente, da ordem de um indivíduo genèticamente ativo por $10.000 \mathrm{~ms} .2$. Dessa ordem é, por exemplo, a densidade de população das seguintes espécies, desde que consideradas nas regiões respectivas em que são mais frequêntes: Trigona (Nannotrigona) testaceicornis LEPELETIER, Trigona (Partamona) testacea KLUG, Trigona (Tetragonisca) jaty F. SMITH, Trigona (Trigona) ruficrus LATREILE, Trigona (Oxitrigona) tataira F. SMITH, Melipona marginata LEPELETIER, Melipona favosa orbignyi GUéRIN, etc.

Examinando, também, o que foi tratado sob o título de "meios de distribuição" (pg. 50), podemos adotar como ráio de vôo médio, para as rainhas, a distância de $100 \mathrm{~ms}$. sendo o dos machos aproximadamente 10 vezes maior, portanto, $1.000 \mathrm{~ms}$.

Sewall Wright (1943) demonstrou que, quando a população efetiva é menor que 1.000 indivíduos, a oscilação genética é de muita importância e levará a espécie a diferençar-se em raças locais. Isso fornecerá um isolamento geográfico que possibilitará o aparecimento de novas espécies.

Essa "população efetiva" ou "população reprodutiva" (N) de Wright é o número de indivíduos genèticamente ativos existentes na "área de reprodução". Essa área pode ser calculada, no caso dos Meliponini, da seguinte maneira, considerando-se separadamente os machos e fêmeas : Se tomarmos uma determinada colónia, podemos dizer que, provavelmente, a rainha provém de uma colónia situada aproximadamente a $100 \mathrm{~ms}$. de distância e o macho que a fecundou de, aproximadamente, $1.000 \mathrm{~ms}$.

A área de reprodução das fêmeas é, nessa base, $\pi .10^{4}$, ou seja $31,416 \mathrm{~ms}^{2}$. Estando presentes em cada 20.000 metros quadrados dois indivíduos genèticamente ativos, sendo um, macho, e o outro, fêmea, podemos concluir que o número efetivo ( $\mathrm{N}$ ) de fêmeas, na área de reprodução, é :

$$
\mathrm{N} q=\left(\pi .10^{4}\right):\left(2.10^{4}\right)=1,57 \text { rainhas. }
$$

Para os machos, a área de reprodução será $\pi .10^{6} \mathrm{~ms}^{2}$ e, como possuem a mesma densidade de população de um macho por $20.000 \mathrm{~ms}^{2}$, teremos, na área citada :

$$
N[\sigma 6]=\left(\pi \cdot 10^{6}\right):\left(2.10^{4}\right)=157,08 \text { machos }
$$


Precisamos lembrar, aquí, que êsses números da população reprodutiva dos machos são correspondentes às áreas geográficas de maior densidade de população, representando, portanto, um $\mathrm{N}$ próximo do máximo, existindo, comumente, em uma determinada zona, nenhuma, uma, duas ou poucas mais espécies com êsse $\mathrm{N}$, sendo que as demais (que na região de Santana de Parnaiba sóbe a mais 30 espécies diferentes) têm uma "população efetiva" muitíssimo inferior. Como exemplo, podemos citar que, até agora, encontrámos, na região de Santana de Parnaiba, São Roque e Cabreúva, cêrca de 50 colónias de Melipona marginata LEP., 25 de $M$. quadrifasciata LEP. e sòmente uma de Lestrimelitta limão F. SMITH; mesmo dando um bom desconto, por as colónias de Lestrimelitta serem mais dificeis de ser encontradas, podemos supor que são, pelo menos, umas 10 vezes mais raras que a Melipona marginata LEP.

Tudo isso quer dizer que, independentemente do processo de fecundação, devemos esperar uma forte oscilação genética que deverá resultar em uma tendência para a homozigotia entre os Meliponini, pois, como postulou Wright (1931, pág. 156), uma grande redução no número de população é seguida por fixação e perda de gens, cada uma na razão de $1 / 4 \mathrm{~N}$ por geração. Esta taxa para os casos como o nosso, em que a população reprodutiva dos machos $\left(\mathbf{N}_{\sigma^{*}}\right)$ é diferente da população reprodutiva feminina, (N $q$ ) torna-se (1931 pg. 109) :

$$
\left(\frac{1}{8 N \sigma^{8}}+\frac{1}{8 N q}\right)\left(1-\frac{1}{8 N \sigma}-\frac{1}{8 N q}\right)
$$

que, para populações razoavelmente grandes, pode escrever-se com boa precisão:

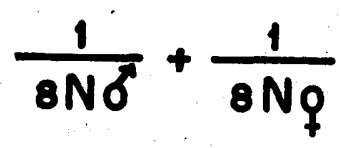

Para o caso particular que calculámos, dos Meliponini, teremos, aplicando a primeira fórmula, por ser mais exata :

$\left[\frac{1}{8 \times 157,08}+\frac{1}{8 \times 1,57}\right]\left[1-\frac{1}{8 \times 157,08}-\frac{1}{8 \times 1,57}\right]=0,0739$ 
Isto significa que, para os Meliponini, tanto as taxas de fixação como perda de gens serão de $7,39 \%$ por geração cada uma. Esta taxa representa um valor mínimo, uma vez que as populações reprodutivas consideradas foram máximas. Supondo, no caso da Lestrimellita limão F. SMITH, que na região de Santana de Parnaiba ela seja 10 vezes mais rara que a Melipona marginata LEP., já elevaria essa taxa para $11,5 \%$.

Um dado que demos aqui apenas calculado grosseiramente é o número de machos por área reprodutiva. Esse dado, entretanto, é de grande importância, sendo a única variável para o cálculo da oscilação genética, pois, como verificámos acima, as frequências das fêmeas são muito baixas, próximas do mínimo, que é uma fêmea por área reprodutiva. Quando o cálculo nos fornece números de indivíduos abaixo de 1 , significa que temos diversas áreas reprodutivas sem nenhum exemplar de espécie considerada.

A homogeneização causada pela oscilação genética dá-se em cada área de reprodução, podendo ir em direções completamente diferentes nas diversas áreas em que a população está contida. Assim, em espécies distribuidas sôbre extensas áreas geográficas, como um grande número de espécies dos Meliponini, a oscilação genética é um fator importantíssimo para a sua heterogeneidade, levando tais espécies a fragmentarem-se em raças locais que poderão mais fàcilmente isolar-se reprodutivamente, originando novas espécies.

Como consequência disso, devemos esperar uma especiação mais rápida nas espécies com distribuição geográfica muito grande, porém, dividida em grupos reprodutivos de pequena densidade de população do que nas espécies, também largamente distribuidas, porém: com densidade de população muito elevada nas áreas reprodutivas. Justamente neste primeiro caso enquadram-se muitos dos Meliponini, o que deve ter influenciado grandemente a multiplicidade de formas e espécies encontradas entre êles. Encontramos; por exemplo, em Melipona marginata LEP., uma variação muito grande, de um lugar para outro : assim, achámos, em S. José do Rio Pardo, umas abelhas muito grandes, com as bandas amarelas abdominais inexistentes ou quase inexistentes; em Botelhos, Minas Gerais, encontrámos colónias de $M$. marginata LEP. muito pequenas; nos arredores de Pirapóra do Bom Jesús, Est. S. Paulo, encontrámos colónias com abelhas' de tamanho médio com bandas abdominais amarelas, distintamente traçadas; de Taunay, Sta. Catarina, recebemos uma colónia com abelhas muito grandes e quase completamente negras, destoando das demais, que pos- 
suem coloração ferruginosa. Isso nos mostra que essa espécie sofreu o efeito da oscilação genética, estando diferençada em diversas raças locais.

Também como exemplo do que acima foi dito conhecemos, entre os Hymenoptera, mais dois casos: um é o de Kinsey (1937), que demonstrou a influência do tamanho das populações no grau de subespeciação nos cinipideos, Kinsey estudando cêrca de 400 espécies da família Cynipidae, e, separando-as em dois grupos, insulares e continentais, verificou a existência de um número muito maior de espécies insulares que continentais. Também, estudando a variação individual dêsses insetos, Kinsey verificou que $4 / 5$ das espécies insulares eram mais constantes que qualquer das espécies continentais e 4/5 das espécies continentais eram muito variáveis. Outro caso é o de Reining (1939) em Bombus, porém, até agora, não pudemos examinar essa publicação, que conhecemos sòmente por referências em Mayr (1947).

Os gens heteróticos devem diminuir sensivelmente o efeito da "oscilação genética" devido ao fato de, em cada geração, os indivíduos heterozigotos terem maiores chances para sobreviver e reproduzir-se. Essa situação, como já mencionámos, é bastante exagerada no gênero Melipona, espécialmente nas espécies com determinação da fêmea fértil por tríplice heterozigotia, onde as rainhas são obrigatòriamente heterozigótas para 3 regiões cromosômicas, sendo o valor de sobrevivência das fêmeas homozigotas, para quaisquer das 3 regiões, igual a zero.

Outro fator que diminui o efeito da oscilação genética é a infiltração de indivíduos entre sub-grupos (Migração), porém, não temos dados para calcular a taxa de migração entre os Meliponini.

Para as populações de Apis mellifera L. a situação é completamente diferente da descrita para as populações de Meliponini, devido ao fato de sua densidade populacional encontrar-se artificialmente elevada. Seu esquema aproxima-se ao de uma população panmítica, sendo que a oscilação genética deve ter pouca ou nenhuma influência em sua extrutura. Assim, considerando as condições descritas para Apis mellifera L. no capítulo sôbre "densidade de população", teremos em cada agrupamento de colónias cêrca de 120 unidades. Para determinarmos, aproximadamente, o número de indivíduos genéticamente ativo por área de reprodução faremos as seguintes considerações:

1) Nos apiários modernos a importância da enxameação é pequena, de modo que, para o cálculo da população feminina 
basta-nos tomar o número de rainhas em cada apiário. Tomaremos aquí o número máximo preconizado, que é de 120 colonias em cada área de pastagem; portanto nosso número será : $\mathrm{N} Q=120$.

2) $\mathrm{Na}$ hipótese dos apiários estarem dispostos em quincôncio, os machos alcançarão os 6 agrupamentos visinhos. Lembraremos aquí que as rainhas são fecundadas, em média, por 1,5 machos. Portanto nosso $N$ đ será :

$$
\mathrm{N} \sigma^{\star}=6 \times 120 \times 1,5=1260
$$

A fixação e perdas de gens é muito pequena em tais populações e deve ser compensada pela taxa de migração, que é forçosamente alta, tanto por zangões que façam vôos exageradamente longos como por introduções de rainhas compradas em apiários distantes.

\section{III - CARACTERES GENETICOS COM PROPRIEDADES ADAPTATIVAS DIFERENTES}

Mencionámos, no capítulo anterior, que um dos fatores que podem contrabalançar o efeito da oscilação genética é a infiltração de um subgrupo em outro, devido ao acontecimento ocasional de hibridizações. Este fenómeno de cruzamentos, mesmo que aconteça com frequências pequenas, tem uma certa importância sôbre, praticamente, quase todos os problemas discutidos no capítulo anterior, pois tais cruzamentos poderão alterar o equilíbrio nas populações, bem como, aumentar consideravelmente a reserva gênica e, com isso, a plasticidade genética.

Parece ser geral, no gênero Melipona, encontrarmos colónias híbridas entre duas subspécies nas regiões onde se superpõem as suas áreas de distribuição geográfica. Temos, por exemplo, dados bastante numerosos sôbre a espécie $M$. quadrifasciata LEP. e verificámos que só existem híbridos na zona de cantacto entre as distribuições geográficas (1) das suas duas subspécies, a saber, anthidioides LEP. e quadrifasciata LEP.

(1) No mapa 7 colocámos um quadrinho e um triângulo, simbolizando, respectivamente, a presença de $M$. quadrifasciata anthidioides LEP. e do híbrido intersubespecífico no Estado do Rio Grande do Sul. Encontrámos êsses dados na coleção do Departamento de Zoologia, S. Paulo, (abelhas numeradas 103197, 103199, 103208, 103210) porém não lhe demos muita importância por supormos, com outros autores, terem sido levadas para lá, de São Paulo, por H. von Iherdig. 
Além disso, a zona de hibridação entre essas duas subspécies coincide com a zona de mudança entre clima tropical e temperado; daí, suspeitarmos que as duas subspécies deveriam possuir propriedades adaptativas a aquelas diferentes condições climáticas. Em Habrobracon juglandis ASHMEAD, pesquisas recentes indicaram que existem diferenças gênicas entre vários grupos geográficos. Assim, os insetos selvagens de New York, Pennsylvania, Iowa e California diferem em um ou dois gens, ou segmentos cromosômicos, como ficou evidenciado pela aparição ou ausência de machos diploịdes (Martin, 1948).

Foram muito bem estudados por Dobzhansky (1948) os valores adaptativos de 4 tipos de inversões no $3^{\circ}$. cromosoma para populações de Drosophila pseudoobscura FROLOVA tendo ficado demonstrado que os valores adaptativos dos tipos cromosômicos dependem da origem geográfica das moscas. Não temos nem podemos fazer pesquizas dessa natureza com os $\mathrm{Me}$ liponini, porém, dos nossos estudos narrados nesta publicação, podemos tirar algumas conclusões, demonstrando a existência de caracteres genéticos com propriedades adaptativas diferentes, de acôrdo com sua origem geográfica, nessa espécie que estudámos.

Examinando o mapa da figura 7, notamos que á zona de distribuição geográfica da Melipona quadrifasciata anthidioides LEP. é o Norte e o Nordeste de S. Paulo, seguindo em direção ao Nordeste do Brasil, enquanto que, ao sul de S. Paulo, seguindo para o sul do Brasil, encontra-se a $M$. quadrifasciata quadrifasciata LEP. A zona ao redor da linha traçada por Cafelândia, Baurú, Ipanema, Araçariguama e Santos, encontramse os híbridos naturais, em grande abundância entre as duas subespécies.

A subespécie quadrifasciata LEP. difere morfologicamente da anthidioides LEP. por a primeira- possuir bandas amarelas inteiras nos tergitos 3 a 6 (às vezes a banda do tergito 3 possui um espaço separando-a), enquanto que essas mesmas bandas na subespécie anthidioides LEP. possuem uma interrupção mediana. Uma amostra de 78 abelhas, que recebemos por gentileza do Sr. Schiller Torres, de Cafelândia, provenientes de uma colónia híbrida, segregava 1:1 para o contraste banda completa contra banda interrompida (Quadro XIV), sugerindo que esta diferença entre as duas subespécies seja devida a um só par de gens. No entanto, 3 colónias híbridas que tivemos oportunidade de observar, provenientes de Araçariguama, não segregavam dessa maneira simples, havendo predominância de indivíduos anthidioides LEP., sendo a frequência dos indivíduos 
quadrifasciata LEP. ao redor de $10 \%$. Não sabemos se nas colónias de Araçariguama a segregação foi atrapalhada por um processo citológico, que suspeitamos existir nas espécies do gênero Melipona, ou se, de fato, temos uma segregação multifatorial e, por acaso, a colméia do $\mathrm{Sr}$. Schiller Torres, segregaria sòmente para um par dos fatores, sendo homozigota para os demais.

QUADRO XIV

\begin{tabular}{l|c|c|c}
\hline \multicolumn{3}{c}{ Melipona quadrifasciata LEP. } \\
(Híbrida) \\
\hline \multicolumn{1}{c|}{ Subespécie } & Obs. & Esp. & $\mathrm{X}^{2}$ \\
\hline quadrifasciata LEP. & 32 & 39 & 1,256 \\
anthidioides LEP. & 46 & 39 & 1,256 \\
& 78 & & 2,513 \\
\hline
\end{tabular}

Infelizmente, as colméias de Araçariguama pereceram, por isso ainda não podemos ter o problema resolvido.

De qualquer forma, porém, interpretamos os valores de sobrevivência dessa subespécies da seguinte forma: na região norte, o Rant (índice de sobrevivência da subespécie anthidioides LEP.) é superior a 1. Conforme se vai aproximando da zona intermediária, êsse valor vai baixando até que, na zona intermediária, possui valor inferior a 1 . Inversamente, supomos, em relação à quadrifasciata LEP., que, na região sul, seu índice de sobrevivência $R$ (quadr.), seja superior a 1 , diminuindo conforme se aproxime da zona intermediária, até que nessa zona atinja valores inferiores a 1 . Assim, na zona intermediária, os híbridos possuiriam valor de sobrevivência superior aos dos homozigotos, ocasionando um equilíbrio com todos os gens presentes na população.

A hipótese que fizemos é adaptada às nossas observações, que seguem o esquema da fig. 9, em que a zona de hibridação é considerada como a zona em que os híbridos possuem maior viabilidade.

Não sabemos dizer quais os fatores que influenciam nas propriedades adaptativas ligadas a êsses caracteres, porém podemos sugerir as seguintes: 
a) Latitude - Apesar da região intermediária fazer um ângulo de $30^{\circ}$ com os paralelos, podemos dizer, aproximadamente, que a latitude de $22^{\circ}$ é limitante para a subespécie quadrifasciata LEP. e a de $24^{\circ}$, para a subespécie anthidioides LEP.

b) Olhando os diversos mapas da publicação de Setzer (1946) : "Contribuição para o estudo do clima do Estado de $\mathrm{S}$. Paulo", verificámos que alguns mapas nos indicam uma variação climática orientada da mesma maneira que a faixa traçada pela região híbrida, inclusive com a mesma protuberância notada, aproximadamente, na zona do Rio Paraiba. Fizemos o esquema da figura $10 \mathrm{com}$ alguns dêsses dados, tais sejam: 1) as curvas isotalantosas anuais (que são as temperaturas médias reais do mês mais quente e do mês mais frio), de $6^{\circ} \mathrm{C}$, $7^{\circ} \mathrm{C}$ e $8^{\circ} \mathrm{C}$, o que provavelmente significaria que a subespécie anthidioides LEP. seja mais sensível a maiores diferenças de temperaturas; 2) As isohietas (curvas de idêntica precipitação de chuva), e 3) a linha ao/ sul da qual o clima é considerado úmido em tôdas as estações do ano. Estes dois últimos dados talvez indiquem que a subespécie anthidioides LEP. resista melhor a períodos de sêca mais prolongados. Poderíamos indicar outros dados climáticos que nos oferecem umas tantas sugestões para explicar a diferente distribuição geográfica dessas duas subespécies, porém, citámos sòmente êstes por não termos dados experimentais sôbre as causas reais das diferentes adaptabilidades. De qualquer maneira, porém, estas duas subspécies constituem um ótimo exemplo da associação. de diferenças de coloração externa e propriedades adaptativas especificas.

\section{IV - CONCLUSÓES E SUMARIO}

1 - Estudámos a composição genética de populações de himenópteros, segundo possuissem um dos dois tipos básicos de reprodução, panmixia ou endogamia, ou o tipo intermediário, reprodução mista.

As populações dos Apinae sociais possuem um processo de reprodução misto, com maior porcentagem de panmixia, como o indicam os seguintes hábitos : a) as colónias, na época de fecundação de novas rainhas, aceitam machos de outras colméias; b) uma colónia de Meliponini, quando não necessita de machos, expulsa-os frequentemente; c) os machos de Meliponini costumam abandonar a colmeia mãe, indo as flôres, onde se empoam de pólen tendo, então, livre entrada em qualquer colónia de sua espécie. 
O que restringe a panmixia nas espécies selvagens de himenópteros sociais é o baixo número de indivíduos genéticamente ativos por área reprodutiva, que nos Meliponini mais frequêntes é de, aproximadamente, 2 fêmeas e 160 machos.

2 - Determinámos que as populações panmíticas de himenópteros, na ausência de mutação, migração ou seleção, devem seguir a regra de Hardy-Weinberg, isto é, todos os gens permanecerão na população em suas proporções iniciais.

3 - Sôbre a atuação de gens heteróticos em populações panmíticas, verificámos, por modêlos matemáticos, o seguinte: na presença de seleção (desconsiderando-se as mutações e migrações), apesar de os machos serem haplóides, é possível obter-se equilíbrio com todos os gens na população desde que seus valores de sobrevivência ( $R A$ e $R a$ ) sejam inferiores a 1 (condição para serem heteróticos). $O$ equilíbrio entre dois gens heteróticos dar-se-á segundo a fórmula

$$
\frac{P}{q}=\frac{R_{A}^{\prime}+R_{a}^{\prime}-2 R_{0} R_{a}^{\prime}}{R_{A}^{\prime}+R_{a}^{\prime}-2 R_{A} R_{A}^{\prime}}
$$

ou, no caso de R' (sobrevivência nos machos) ser igual a $R$ (sobrevivência nas fêmeas):

$$
\frac{p}{q}=\frac{R_{A}+R_{a}-2 R_{a}^{2}}{R_{A}+R_{a}-2 R_{A}^{2}}
$$

há, entretanto, uma restrição: RA não pode exceder Ra além de um limite determinado pela fórmula

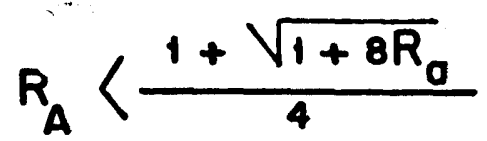

pois, se assim suceder, o equilíbrio será alcançado quando sòmente houver presença do genotipo mais viável na população. Essas mesmas fórmulas podem ser aplicadas em populações diplóides, a gens ligados ao sexo que são representados em dose simples no sexo heterogamético. 
Citámos, como o principal documento experimental da existência de grande número de gens heteróticos entre os himenópteros sociais, a perda de vigor, devido ao endocruzamento artificial, e o respectivo retôrno ao vigor pelo intercruzamento de linhagens puras de Apis mellifera L., nas experiências de especialistas norte-americanos.

Sendo os machos haplóides, e, por isso, puros para todos os fatores, um grande número de gens heteróticos em uma população deve reduzir suas viabilidades e aumentar sua variabilidade em relação às fêmeas. A maior variabilidade dos machos em relação às fêmeas foi demonstrada para as três tribus dos Apinae sociais, tomando-se por base medições no comprimento da língua (que é orgão de vital importância para essas abelhas) nas espécies Apis mellifera LINNEAUS, $M$. quadrifasciata LEP.,Bombus rubicundús SMITH, Melipona marginata LEP.

Outros detalhes que citámos, relacionados com gens heteróticos, foram :

a) Verificámos uma maior mortalidade entre os machos de $M$. quadrifasciata LEP. que entre as fêmeas.

b) Casteel e Phillips verificaram que os machos de diversas amostras de Apis mellifera L. tinham 7 vezes mais anormalidades que as operárias.

c) Logo após emergirem, os machos têm uma variação muito grande, caracterizada por tipos extremos, pequenos, porém, os machos adultos, que coletámos, possuiam uma variação quase da mesma ordem que a das operárias.

Esses três pontos podem ser explicados do seguinte modo: se os responsáveis por essas anormalidades fossem, ùnicamente, gens subviáveis, a sua eliminação seria inevitável e deveríamos esperar, em poucas gerações, uma homozigotia para os gens mais viáveis, desaparecendo essa grande variabilidade entre os machos, que é comumente encontrada nas três tribus dos Apinae sociais. Portanto, os gens que determinam tais caracteres deverão possuir efeitos heteróticos nas fêmeas. Nossas observações foram feitas em material selvagem, que possuem, normalmente, seus gens em equilíbrio.

4 - O estudo por modêlo matemáticos mostrou-nos que os gens de isolamento (com o heterozigoto possuindo viabilidade menor que ambos homozigotos) só têm oportunidade de sobrevivência no caso de espécies subdivididas em populações muito pequenas, devido a muita importância da frequência inicial dos gens, ou nos limites da distribuição de duas espécies ecológicamente separadas. Estes gens de isolamento só poderão ter papel importante em espécies com número de indivíduos por 
área reprodutiva muito baixo, pois, assim, qualquer mutação dêsse tipo que ocorra terá, naquele grupo reprodutivo, de início, uma frequência muito alta. Os gens de isolamento só poderão acumular-se em uma população, a ponto de constituirem uma nova espécie, se houver um isolamento ecológico ou geográfico. Não havendo um isolamento absoluto é bem provavel que combinações gênicas que impeçam os cruzamentos $\mathrm{AA} \times$ aa dominem na população, pois, por definição, os indivíduos $\mathrm{Aa}$ terão menor valor adaptativo. Um esquema dêsse tipo foi encontrado por Koopman (1950).

5 - Os gens limitados a um dos sexos apresentam particularidades definidas entre as populações panmíticas de himenópteros conforme o sexo afetado seja feminino ou masculino. Teòricamente ficou demonstrado que os gens limitados ao sexo feminino são de excepcional importância para os himenópteros devido ao fato de seguirem tôdas as regras e esquemas de uma população diploide, tendendo, nos mesmos casos, para os mesmos limites. Demonstrámos, também, que na natureza, os gens limitados ao sexo feminino são, relativamente, comuns, tendo citado, como exemplos: a) a facilidade de as fêmeas dos himenópteros sociais responderem vigorosamente a fatores tróficos, b) os fatores determinantes de casta no gênero Melipona ( $A$, B e C), c) dois gens, nas espécies Trigona (Plebeia) masquito F. SMITH (Dc) e Melipona marginata LEPELETIER (Am).

Dois ou mais aleles limitados ao sexo masculino só poderão coexistir quando seus valores de sobrevivência forem iguais entre sí.

6 - Um fator que poderá ser de importância secundária nas populações de espécies diplóides e que é importante nas populações de himenópteros é o tempo, representado pela duração dos indivíduos genèticamente ativos, pela circunstância de favorecer o mecanismo de gens heteróticos. Talvez seja por uma adaptação a um tal sistema que as rainhas dos himenópteros sociais e as respectivas cargas de espermatozóides depositadas em suas espermatecas tenham uma vida relativamente longa.

7 - As colónias dos himenópteros sociais comportam-se como indivíduos em competição, e, portanto, teremos de admitir índices de sobrevivência para elas, devendo ser assim descriminados : um índice que meça o número de ovos produzidos, outro que meça o valor das operárias, e outro que meça o valor adaptativo da rainha.

8 - Por um pequeno estudo nas populações de himenópteros endogâmicos verificámos que: 
a) Quando não houver seleção, se considerarmos dois aleles A e a, teremos, a fim de um certo número de gerações (teóricamente após infinitas gerações), sòmente fêmeas (AA) fecundadas por machos (A) e fêmeas (aa) fecundadas por machos.(a); esta situação, após alcançada, será repetida indefinidamente.

b) $O$ processo de endogamia encontrado na natureza é o de acasalamento entre irmãos, porém, podemos, por meio de fecundação artificial, fazer outros tipos de endocruzamento, tais sejam : cruzamento entre mãe e filho e cruzamento entre tia e sobrinho. $O$ processo que conduz mais rápidamente à homozigotia é o de cruzar mãe com filho.

c) Mesmo em populações endogâmicas de himenópteros há possibilidade teórica de haver equilíbrio com todos os gens na população, sendo condições necessárias: I) índices de ambos homozigotos inferiores a 0,75 , II) que os acasalamentos não tenham alcançado o equilíbrio a que nos referimos acima, isto é, o de sòmente existirem fêmeas $\mathrm{AA}$ ou aa fecundadas por machos $\mathrm{A}$ ou a, respectivamente, III) que os gens considerados não difiram entre si mais do que o permite a fórmula (de Pimentel Gomes) :

$$
\begin{aligned}
4 R_{A}^{5} & +8 R_{0} R_{A}^{4}-4 R_{0} R_{A}^{3}+8 R_{a}^{3}\left(R_{a}-1\right) R_{A}^{2}- \\
& -R_{0}^{2}\left(4 R_{0}^{2}+4 R_{a}-1\right) R_{A}+2 R_{0}^{3}<0
\end{aligned}
$$

Nestas condições, podemos concluir que os gens heteróticos não devem ter importância nas populações de himenópteros endogâmicos pois as condições para o seu estabelecimento são muito severas.

9- A mutação gênica afeta as populações de himenópteros mais intensamente que as populações diplóides, devido à situação haplóide dos machos. Assim, para gens letais, teremos :

$$
\mathrm{u}=\mathrm{s},
$$

sendo $u$ a taxa de mutação, e $s$ a frequência do gen mutado na população masculina.

10 - Entre os fatores importantes para a competição entre as espécies de Meliponini,, citámos e analisámos três : capacidade de vôo da operária, capacidade de coletar alimento da operária e capacidade de postura da rainha. Entre outras ob- 
servações feitas neste sentido, citámos a variabilidade do comprimento da língua, de colónia para colónia, na espécie $M$. quadrifasciata LEP., o processo de retransporte de pólen utilizado pelos Meliponini, que é no estômago, e o fato de as colónias mais populosas serem, aproximadamente, as mais frequêntes.

Considera-se a competição entre diferentes espécies como um dos agentes responsáveis pela densidade de população.

11 - Citámos os diversos meios de defesa utilizados pelos Meliponini para resistirem à predação por parte dos outros animais, tendo pôsto em particular destaque o disfarçamento da colónia e o mimetismo com outras abelhas possuidoras de aguilhão.

Ainda dentro do assunto de predação relatámos o processo utilizado pelas Lestrimelittas para o saque.

12 - Considerando a plasticidade genética de bastante importância para a evolução de uma espécie, pensámos deverem ser de particular importância dois mecanismos: a) variações citológicas e b) reserva gênica.

a) Sob o primeiro mecanismo, considerámos importantes: as duplicações, a poliploidia e a polisomia. Sôbre duplicação, apesar de ser, teòricamente, importante, não temos dados sôbre a sua ocorrência entre os Hymenoptera. Quanto à poliploidia e polisomia, citámos os seguintes exemplos : 1) a maioria das espécies de Diprion com número haplóide de cromosoma igual a 7 e uma espécie, Diprion simile ATG, possuindo $14 ; 2$ ) a espécie Apis mellifera L., possuindo 16 cromosomas (n), porém, exibido pareamento secundário, formando 8 diadas, no fim da I divisão e o início da II da meiose no macho, e as espécies do gênero Melipona com 9 cromosomas. Correlacionando-se estes dois casos, pode-se sugerir uma provável origem de um estoque primitivo de $\mathrm{n}=8$, sendo as Apis oriundas por tetraploidia $(\delta=n+n)$ e as Meliponas por trisomia $(\sigma=n+1)$. Sugerimos que a origem do cromosoma sexual em Apis esteja ligada à diplo-tetraploidia.

b) Quanto à reserva gênica, analisámos qual a contribuição para a plasticidade genética dos diversos tipos de mutantes possíveis, que são: 1) subviáveis (incluindo letais), 2( superviáveis, 3) de isolamento, 4) neutros, 5) heteróticos. Considerámos como os mais importantes para a plasticidade genética os dois últimos tipos.

13 - Computámos a distância média a que vão as operárias formar uma nova colónia, e a onde vai uma nova rainha para ser fecundada e estabelecer- se, como sendo de aproximadamente $100 \mathrm{~ms}$. A dispersão da fêmea pode, portanto, ser avaliada 
em, aproximadamente, $100 \mathrm{~ms}$. por ano, pois na natureza as colónias de Meliponini soltam um ou, excepcionalmente, dois enxames por ano. Esses dados foram obtidos tomando-se por base a Melipona marginata LEP. Trigona (Tetragonisca) jaty F. SMITH, sendo, provavelmente, diferentes, de espécie para espécie.

Para os machos, computámos a distância a que se locomoverão em, aproximadamente, 10 vezes a das fêmeas, portanto, de $1.000 \mathrm{~ms}$., tomando-se por base observações em M. quadrifasciata LEP. Este dado, não obstante sua grande importância está sòmente estimado grosseiramente.

A densidade da população genéticamente ativa, se bem que aparente ser maior para fêmeas, pelo fato de existirem alguns milhares para uma só fêmea em um enxame, é, na realidade, de, aproximadamente, um indivíduo por $10.000 \mathrm{~ms}^{2}$, para as espécies mais frequêntes em cada região, tanto para machos como para fêmeas. Isto, porque o que importa na genética de populaçỏes são os indivíduos que deixam descendentes, e no caso dos Apinae sociais, só os deixam a rainha e os machos que a fecundaram. Em média, a rainha de Apis mellifera é fecundada por 1,5 machos, e, segundo as atuais evidências, uma rainha de Meliponini é fecundada uma só vez, por um único macho.

Como a população dos Meliponini é muito pequena, suspeitamos que a oscilação genética devesse ser muito importante e, usando uma fórmula de Sewall Wright pudemos calcular a taxa de fixação e perda de gens. Para as espécies com maior densidade de população (1 indivíduo genèticamente ativo por $10.000 \mathrm{~m}^{2}$ ), verificámos que essa taxa de fixação e perda de gens é de; aproximadamente, $7 \%$, e, em espécies 10 vezes mais raras ainda, ela deve ser de; aproximadamente, $11 \%$. Em $M$. -marginata LEP. observámos que, de zona para zona, há uma variação muito grande, tanto no tamanho, na coloração em geral, como nas bandas amarelas dos tergitos abdominais.

Devido sua organização social, com os cuidados prestados a fêmea fertil e com a enxameagem, com as reservas alimentares para suprir a colónia durante períodos em que há falta, a densidade de população nos Apini e Meliponini é muito constante. Esse fato garante a subsistência das espécies de Meliponini apesar da sua baixa densidade de população.

14 - Há espécies adaptadas às mais variadas condições ecológicas, como a Trigona (Tetragonisca) jaty F: SMITH;' Trigona (Nannotrigona) testaceicornis LEP., e outras estreitamen- 
te limitadas a uma determinada zona a Melipona fuscata melanoventer SCHWARZ.

Verificámos, em algumas espécies cuja distribuição gèográfica se superpõe, que as condições ecológicas escolhidas para localização da colónia são bem'diferentes, e g., M. marginata LEP. e M. quadrifasciata LEP:

Estudando a distribuição geográfica de $M$. quadrifasciata LEP. verificámos que ao Norte do Estado de S. Paulo até o Nordeste do país ela é representada pela subespécie anthidioides LEP. e do sul do Estado de São Paulo até o Rio Grande do Sul é representada pela subespécie quadrifasciata LEP., existindo uma faixa mediana onde são encontradas colónias híbridas, naturais. A subespécie quadrifasciata LEP. difere, morfologicamente, da anthidioides LEP. por possuir 4 bandas amarelas completas, enquanto que a última as possui interrompidas. Achamos interessante encontrar um caracter morfológico determinado por um ou dois gens, com propriedades adaptativas diferentes, dependendo da origem geográfica das colónias.

Explicámos a zona marginal de superposição nas áreas das duas subespécies, onde a frequência de híbridos inter-subespecíficos é relativamente alta em certas zonas, da maneira seguinte: sendo cada subespécie adaptada a uma determinada zona climática, podemos supôr que a adaptação de ambas seja menos perfeita na zona de mudança das diversas condições climáticas. Os híbridos, tendo propriedades paternais combinadas, deverão ser melhor adaptados às condições da zona de transiḉão. Dêste modo, os híbridos serão heteróticos e estabelecer-se-á um equilíbrio na população com a presença de ambas subespécies e seus híbridos.

\section{SUMMARY}

This paper deals with problems on population genetics in Hymenoptera and particularly in social Apidae.

1) The studies on populations of Hymenoptera were made according to the two basic types of reproduction: endogamy and panmixia.

The populations of social Apinae have a mixed method of reproduction with higher percentage of panmixia and a lower of endogamy. This is shown by the following a) males can enter any hive in swarming time; b) males of Meliponini are expelled from hives which does not need them, and thus, are forced to look for some other place; c) Meliponini males were 
seen powdering themselves with pollen, thus becoming more acceptable in any other hive. The panmixia is not complete owing to the fact that the density of the breeding population as very low, even in the more frequent species as low as about 2 females and 160 males per reproductive area.

We adopted as selection values (or survival indices) the expressions according to Brieger $(1948,1950)$ which may be summarised as follows; a population: $\mathrm{p}^{2} \mathrm{AA}+2 \mathrm{pq} \mathrm{Aa}+\mathrm{q}^{2 a a}$ became after selection: $x p^{2} A A+2 p q A a+z$ q2aa. For algebraics facilities Brieger divided the three selective values by $\mathrm{y}$ giving thus:

$\frac{\mathrm{x}}{\mathrm{y}} \mathrm{p}^{2} \mathrm{AA}+\frac{\mathrm{y}}{\mathrm{y}} 2 \mathrm{pq} \mathrm{Aa}+\frac{\mathrm{z}}{\mathrm{y}} \mathrm{q}^{2} \mathrm{aa}$. He called $\frac{\mathrm{x}}{\mathrm{y}}$ of RA and $\frac{\mathrm{z}}{\mathrm{y}}$ of

$\mathrm{Ra}$, that are survival or selective index, calculated in relation to the heterozygote. In our case all index were calculated in relation to the heterozygote, including the ones for haploid males; thus we have :

\section{RA surveval index of genotype AA \\ $\mathrm{Ra}$ surveval index of genotype aa \\ R'A surveval index of genotype A \\ R'a surveval index of genotype a \\ 1 surveval index of genotype $\mathrm{Aa}$}

The index R'A ande R'a were equalized to RA and Ra, respectively, for facilities in the conclusions.

2) Panmitic populations of Hymenoptera, barring mutations, migrations and selection, should follow the Hardy-Weinberg law, thus all gens will be present in the population in the inicial frequency (see Graphifc 1).

3) Heterotic genes: If mutation for heterotic gene

$$
\text { ( } 1>\mathrm{RA} \geqq \mathrm{Ra} \text { ) }
$$

occurs, an equilibrium will be reached in a population when :

$$
\begin{aligned}
& P=\frac{R_{A}+R_{0}-2 R_{0}^{2}}{2\left(R_{A}+R_{0}-R_{A}^{2}-R_{0}^{2}\right)} \\
& q=\frac{R_{A}+R_{0}-2 R_{A}^{2}}{2\left(R_{A}+R_{0}-R_{A}^{2}-R_{0}^{2}\right)}
\end{aligned}
$$


A heterotic gene in an hymenopteran population may be maintained without the aid of new mutation only if the survival index of the most viable mutant (RA) does not exced the limiting value given by the formula:

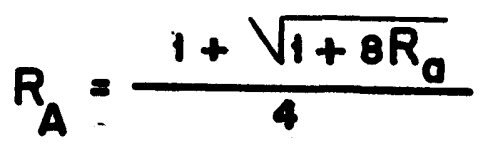

If RA has a value higher thah the one permitted by the formula, then only the more viable gene will remain present in the population (see Graphic 10). The only direct proof for heterotic genes in Hymenoptera was given by Mackensen and Roberts, who obtained offspring from Apis mellefera L. queens fertilized by their own sons. Such inbreeding resulted in a rapid loss of vigor the colony; inbred lines intercrossed gave a high hybrid vigor. Other fats correlated with the "heterosis" problem are; a) In a colony $M$. quadrifasciata Lep., which suffered severely from heat, the percentage of deths omong males was greater than among females; b) Casteel and Phillips had shown that in their samples (Apis melifera L). the males had 7 times more abnormalities tian the workers (see Quadros IV to VIII) ; c) just after emerging the males have great variation, but the older ones show a variation equal to that of workers; d) The tongue lenght of males of Apis mellifera L., of Bombus rubicundus Smith (Quadro X), of Melipona marginata Lep. (Quadro XI), and of Melipona quadrifasciata Lep. Quadro IX, show greater variationthan that of workers of the respective species. If such variation were only caused by subviables genes a rapid increasse of homozigoty for the most viable alleles should be expected; then, these .wild populations, supposed to be in equilibrium, could not show such variability among males. Thus we conclude that heterotic genes have a grat importance in these cases.

4) By means of mathematical models, we came to the conclusion tht isolating genes $(R A \supseteq R a>1)$, even in the case of mutations with more adaptability, have only the oportunity of survival when the population number is very low (thus the frequency of the gene in the breeding population will be large just after its appearence). A pair of such alleles can only remain present in a population when in border regions of two races or subspecies. For more details see Graphics 5 to 8 .

5) Sex-limited genes affecting only females, are of great importance toHymenoptera, being subject to the same limits and formulas as diploid panmitic populations (see formulas 12 
and 13). The following examples of these genes were given: a) caste-determining genes in the genus Melipona; b) genes permiting an easy response of females to differences in feeding in almost all social Hymenoptera; c) two genes, found in wild populations, one in Trigona (Plebeia) mosquito F. SMITH (quadro XII) and other in Melipona marginata marginata LEP. (Quadro XIII, colonies 76 and 56) showing sex-limited effects.

Sex-limited genes affecting only males do not contribute to the plasticity or genic reserve in hymenopteran populations (see formula 14).

6) The factor time (life span) in Hymenoptera has a particular importance for heterotic genes. Supposing one year to be the time unit and a pair of heterotic genes with respective survival indice equal to $\mathrm{RA}=0,90$ and $\mathrm{Ra}=0,70$ to be present; then if the life time of a population is either one or two years, only the more viable gene will remain present (see formula 11). If the species has a life time of three years, then both alleles will be maintained. Thus we conclude that in specis with long lif-time, the heterotic genes have more importance, and should be found more easily.

7) The colonies of social Hymenoptera behave as units in competition, thus in the studies of populations one must determine the survival index, of these units which may be subdivided in indice for egg-laying, for adaptive value of the queen, for working capacity of workers, etc.

8) A study of endogamic hymenopteran populations, reproduced by sister $x$ brother mating (fig. 2), lead us to the following conclusions: a) without selection, a population, heterozygous for one pair of alleles, will consist after some generations (theoretically after an infinite number of generation) of females $A A$ fecundated with males $A$ and females $a a$ fecundated with males $a$ (see Quadro I). b) Even in endogamic population there is the theoretical possibility of the presence of heterotic genes, at equilibrium without the aid of new mutations (see Graphics 11 and 12), but the followingi conditions must be satisfied: I - surveval index of both homozygotes (RA e Ra) should be below 0,75 (see Graphic 13); II - The most viable allele must not exced the less viable one by more than is permited by the following formula (Pimentel Gomes 1950) (see Grafic 14) : 


\section{$4 R_{A}^{5}+8 R_{0} R_{A}^{4}-4 R_{0} R_{A}^{3}+8 R_{0}^{3}\left(R_{0}-1\right) R_{A}^{2}-$ $-R_{0}^{2}\left(4 R_{0}^{2}+4 R_{0}-1\right) R_{A}+2 R_{0}^{3}<0$}

Considering these two conditions, the existance of heterotic genes in endogamic populations of Hymenoptera becames very improbable though not-impossible.

9) Genic mutation offects more hymenopteran than diploid populations. Thus we have for lethal genes in diploid populations : $\mathrm{u}=\mathrm{q} 2$, and in Hymenoptera: $\mathrm{u}=\mathrm{s}$, being $u$ the mutation ratio and $s$ the frequency of the mutant in the male population.

10) Three factors, important to competition among species of Meliponini were analysed: flying capacity of workers, food gathering capacity of workers, egg-laying of the queen. In this connection we refer to the variability of the tongue lenght observed in colonies from several localites, to the method of transporting the pollen in the stomach, from some pots (Melliponini storage alveolus) to others (e. g. in cases of pillage), and to the observation that the species with the most populous hives are almost always the most frequent ones also.

11) Several defensive ways used for Meliponini to avoid predation are cited, but special references are made upon the camouflage of both hive (fig. 5) and hive entrance (fig. 4) and on the mimetism (see list in page). Also under the same heading we described the method of Lestrimelitta for pillage.

12) As mechanisms important for promoting genetic plasticity of hymenopteran species we cited: a) cytological variations and $b$ ) genic reserve. As to the former, duplications and numerical variations of chromosomes were studied. Diprion simile ATC was cited as example for polyploidy. Apis mellifera L. $(\mathrm{n}=16)$ also sugests polyploid origen since: a) The genus Melipona, which belongs to a related tribe, presents in all species so far studied $n=9$ chromosomes and $b$ ) there occurs formation of dyads in the firt spermatocyte division. It is sugested that the origin of the sex-chromosome of Apis mellifera L. may be related to the possible origin of diplo-tetraploidy in this species.

With regards to the genic reserve, several possible types of mutants were discussed. They were classified according to their survival indices; the heterotic and neutral mutants must 
be considered as more important for the genic reserve.

13) The mean radius from a mother to a daghter colony was estimated as 100 meters. Since the Meliponini hives swarm only once a year we may take 100 meters a year as the average dispersion of female Meliponini in ocordance to data obtained from Trigona (tetragonisca) jaty F. SMITH and Melipona marginata LEP., while other species may give different values. For males the flying distance was roughly estimated to be 10 times that for females. A review of the bibliography on Meliponini swarm was made (pg. 43 to 47 ) and new facts added.

The population desity (breeding population) corresponds in may species of Meliponini to one male and one female per 10.000 square meters. Apparently the males are more frequent than the females, because there are sometimes many thousands of males in a swarm; but for the genic frequency the individuals which have descendants are the ones computed. In the case of Apini and Meliponini, only one queen per hive and the males represented by. the spermatozoos in its spermateca are computed. In Meliponini only one male mate with the queen, while queens of Apis mellifera $\mathrm{L}$. are fecundated by an average of about 1, 5 males. (Roberts, 1944).

From the date cited, one clearly sees that, on the whole, populations of wild social bees (Meliponini) are so small that the Sewall Wright effect may become of great importance. In fact applying the Wright's formula :

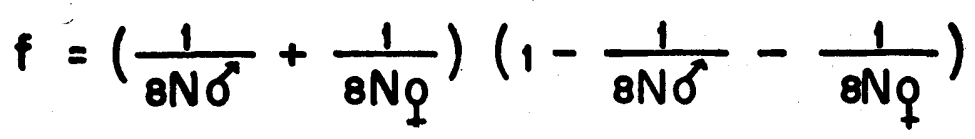

which measures the fixation and loss of genes per generation, we see that the fixation or loss of genes is of about $7 \%$ in the more frequent species, and rarer species about $11 \%$. The variation in size, tergite color, background color, etc, of Melipona marginata Lep. is atributed to this genetic drift.

A detail, important to the survival of Meliponini species, is the constance of their breeding population. This constance is due to the social organization, $i$. e., to the care given to the reproductive individuals (the queen with its sperm pack), to the way of swarming, to the food storage intended to control variations of feeding supply, etc.

14) Some species of the Meliponini are adapted to various ecological conditions and inhabit large geographical areas 
(e. g. T. (Tetragonisca jaty F. SMITH), and Trigona (Nannotrigona testaceicornis LEP.) while others are limited to narrow regions with special ecological conditions (e. g. M. fuscata melanoventer SCHWARZ). Other species still, within the same geographical region, profit different ecological conditions, as do $M$. marginata LEP. and $M$. quadrifasciata LEP.

The geographical distribuition of Melipona quadrifasciata LEP. is different according to the subspecies: a) subsp anthidiodes LEP. (represented in Fig. 7 by black squares) inhabits a region fron the North of the S. Paulo State to Northeastern Brazil, b) subspecies quadrifasciata LEP., (marked in Fig. 7 with black triangles) accurs from the South of S. Paulo State to the middle of the State of Rio Grande do Sul (South Brazil). In the margined region between these two areas of distribution, hibrid colonies were found (Fig. 7, white circles); they are shown with more details in fig. 8, while the zone of hybridization is roughly indicated in fig. 9 (gray zone). The subspecies quadrifasciata LEP., has 4 complete yellow bands on the abdominal tergites while anthidioides LEP. has interrupted ones. This character is determined by one or two genes and gives different adaptative properties to the subspecies. Figs. 10 shows certains meteorological isoclines which have aproximately the same configuration as the limits of the hybrid zone, suggesting different climatic adaptabilities for both genotypes. The existance of a border zone between the areas of both subspecies, where were found a high frequency of hybrids, is explained as follows : being each subspecies adapted to a special climatic zone, we may suppose a poor adaptation of either one in the border region, which is also a region of intermediate climatic conditions. Thus, the hybrids, having a combination of the parent qualities, will be best adapted to the transition zone. Thus, the hybrids will become heterotic and an equilibrium will be reached with all genotypes present in the population in the border region.

\section{LITERATURA CITADA}

ABỤSHADY, A. Z. - 1948 - Carniolans vs, Italians. Gleanings in Bee Culture, $76(3): 149$.

ALPATOV, W. W. 1929 - Biometrical studies on variation and races of the honey bee (Apis mellifera L.) Quart. Rev. Biol., 4: 1-58, 21 figs, 25 tabelas. 
BATEMAN, A. J. - 1949 - Pollinating agents and populations genetics. Proc. Eight Int. Congr. Gen., pg. 532.

BRIEGER, F. G. - 1942 - Coeficiente de variação e índices da variança. Bragantia, 2: 313-332.

- - 1944 - Considerações sôbre o mecanismo da evolução. An. Esc. Sup. Agr. "Luiz de Queiroz", 1: 174-211, figs. 1-9.

1946 - Limites unilaterais e bilaterais na análise estatística. Bragantia, 6: 479-545, figs. 1-6. 1948 - Contribuições à teooria da genética em populações. An. Esc. Sup. Agr. "Luiz de Queiroz"; 5: 65-160.

- 1949 - The modifier shift as an evolutionary-mechanism. Proc. Eight Int. Congr. Gen., pgs. 542-543.

Genetics (em impressão).

CASTEEL, D. B. and E. F. PHILLIPS - 1903 - Comparative variability of drones and workers of the honey bee. Biol. Bull., 6: 18-37, 4 figs., 7 táboas.

DADANT, R. H. - 1948 - The Southern Conference (The breeding program). Am. B. Journal, 88 (1): 31.

DOBZHANSKY, TH. - 1941 - Genetics and the origin of species. Revised Edition. Columbia University Press. New York.

Espécies (Conferências). 110 pgs. Bol. $n \cdot 2$ dos Cursos de Aperf. e Esp., Centro Nacional de Ensino e Pesquizas Agronómicas - Rio de Janeiro.

- 1947 - Genetics of natural populations. XIV. A response of certain gene arrengements in the trird chromosome of Drosophila pseudoobscura to natural selection. Genetics, 32: 142-160.

Carnegie Institution of Washington, Year Book $n$ 47: 193-203.

DOBZHANSKY, THEODOSIUS E SEWALL WRIGHT - 1943 - Genetics of Natural populations. X. Dispersion rates in Dros ophila pseudoobscura. Genetics 28: 304-340. 
DOZORCEVA, R. L. - 1936 - The morphology of cromosomes of the Ichneumon Pteromulus puparum. C. R. Acad. U.R.S.S. Apud Dreyfus e Breuer, 1944).

DREYFUS, A. e M. E. BREUER - 1944 - O sexo nos himenópteros arrenótocos. Bol. Fac. Fil. Cien. Let., Biologia Geral n. 5, pgs. 1-103, 74 figs.

DRORY, EDOUARD - 1873 - Nouvelles observations sur les mélipones. Le Rucher du Sud-Ouest, 1: 59-61. 30: $281-286$.

1877 - Les mélipones et les trigones. Rucher, Journ. d'Apiculture Rationnelle, 5:144-149.

DUBININ, N. P. and D. D. ROMASHOFF - 1932 - Die genetische Struktur der Art und ihre Evolution. Biol. Journ. Moscou, 1: 52-95.

EDITOR do Gleanings in Bee Culture - 1948 - Races of Bees. Gleanings in Bee Culture, 76 (1): 29.

FAIRCHILD, DAVID and O. W. BARRETT - Notes on the copulation of Bombus fervidus. Proc. Ent. Soc., Washington, 8: $13-14,1 \mathrm{pl}$.

FARRAR, C. L. - 1947 - More honey from bees. Yearbook of Agriculture, 1943-1947 - Science in Farming, pgs. 680-685. 1948 - Apparatus for artifitial insemination of queen bees. Am. B. Journ., 88 (4): 190-191, April.

FIEBRIG, KARL - 1908 - Skizzen aus dem Leben einer Melipone aus Paraguay. Zeitschr. Wiss. Insecktenbiologie, 3: 374-386, fgs. 1-3.

FISHER, R. A. - 1930 - The genetical theory of natural selection. xiv, 272 pp., Oxford, Clarenden Press.

FRISON, THEODORE H. - 1927 - The fertilization and hibernation of queens bumblebees under controlled condition. Jorn. Ec. Ent., 20:522-527.

HALDANE, J. B. S. - 1936 - The amount of heterozygosis to 

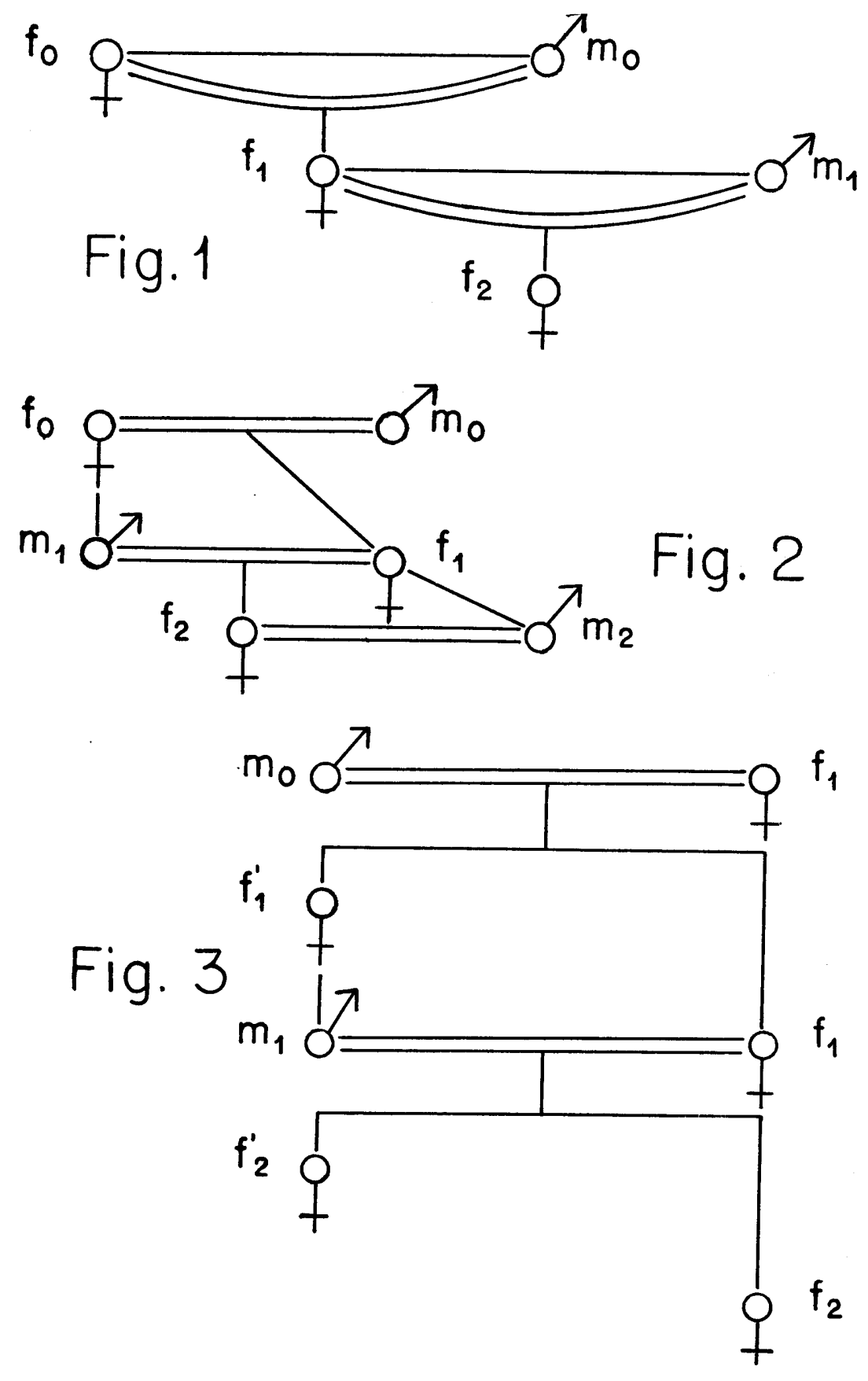


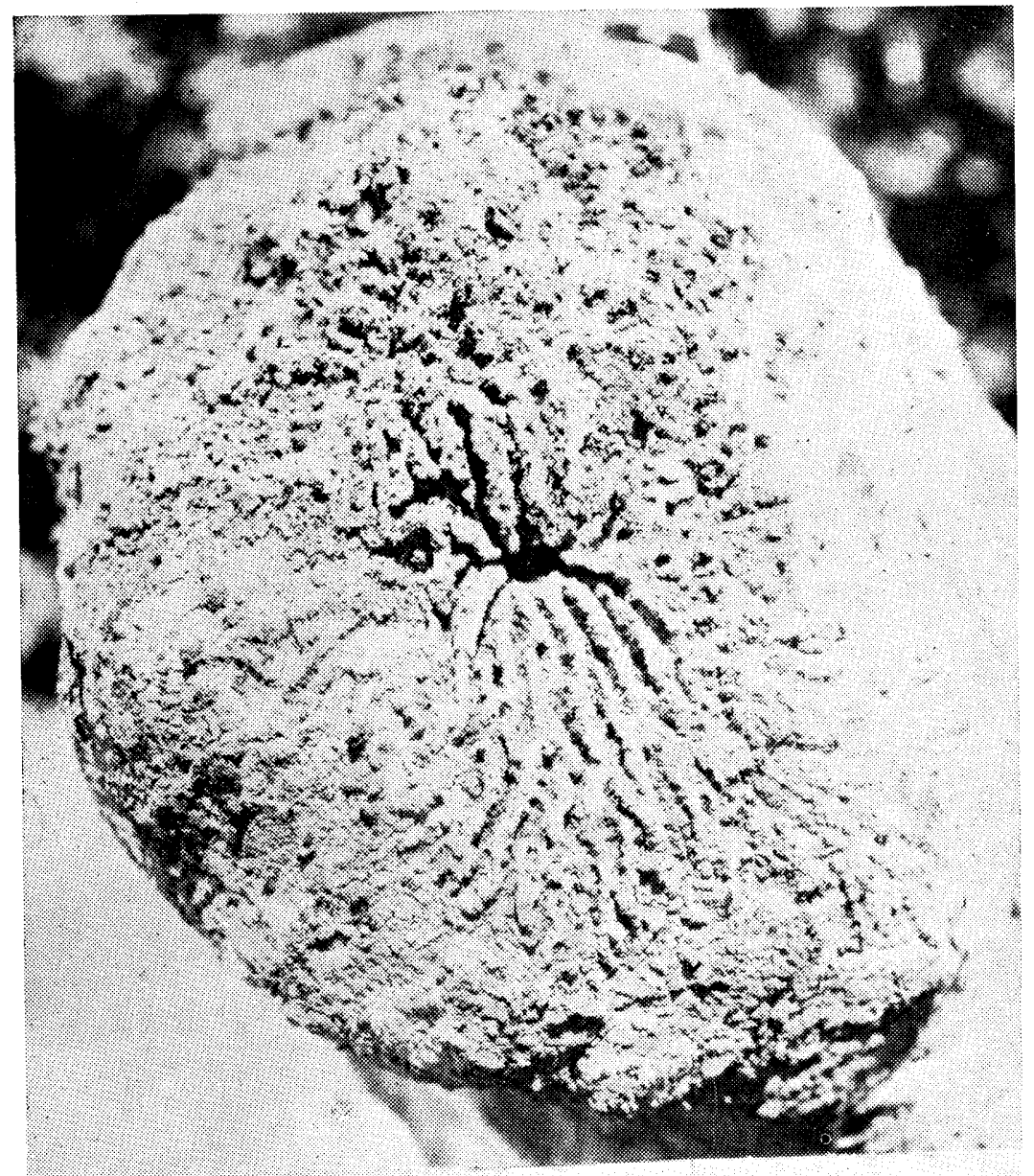

Fig. 4 

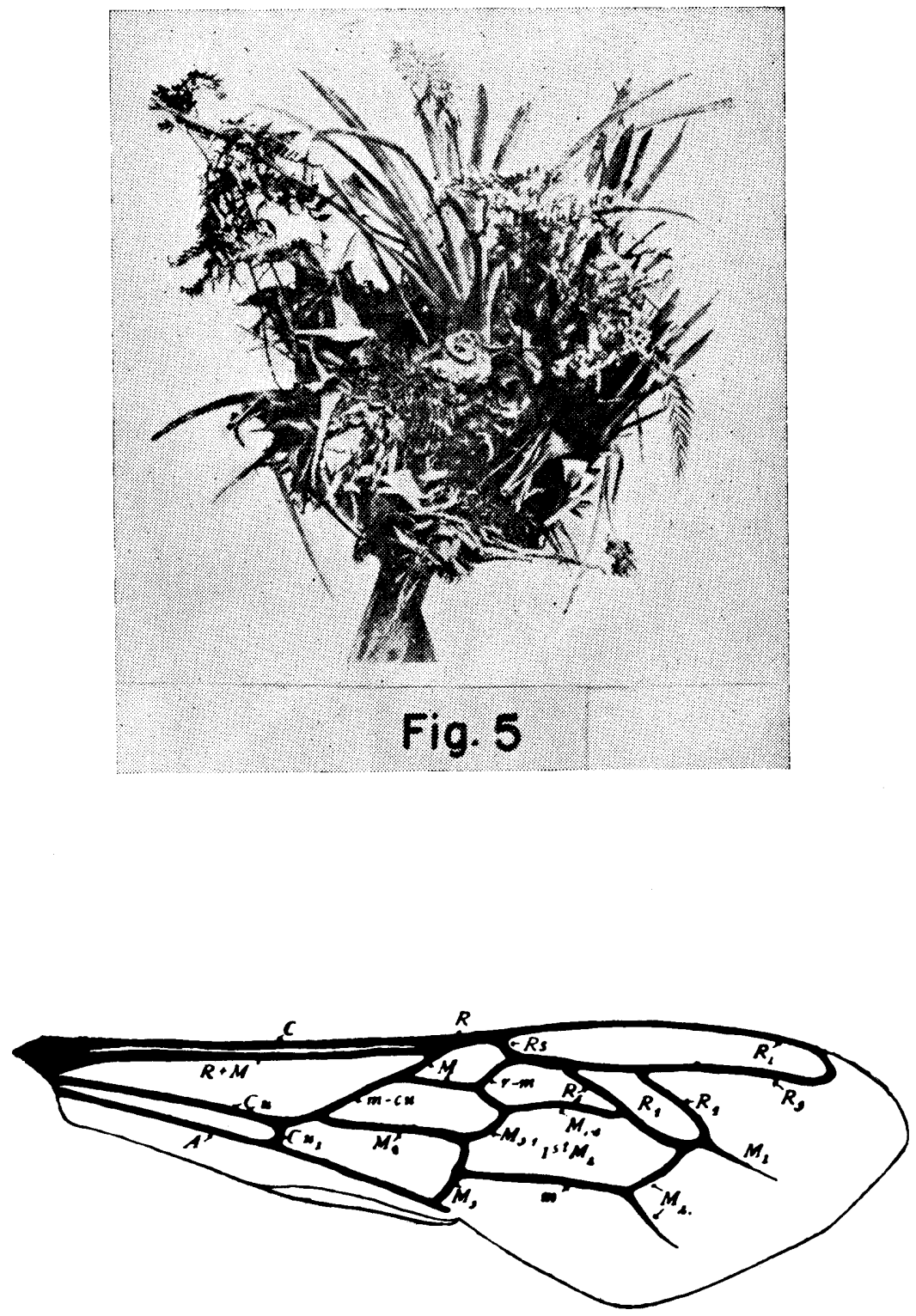

Fig. 6 


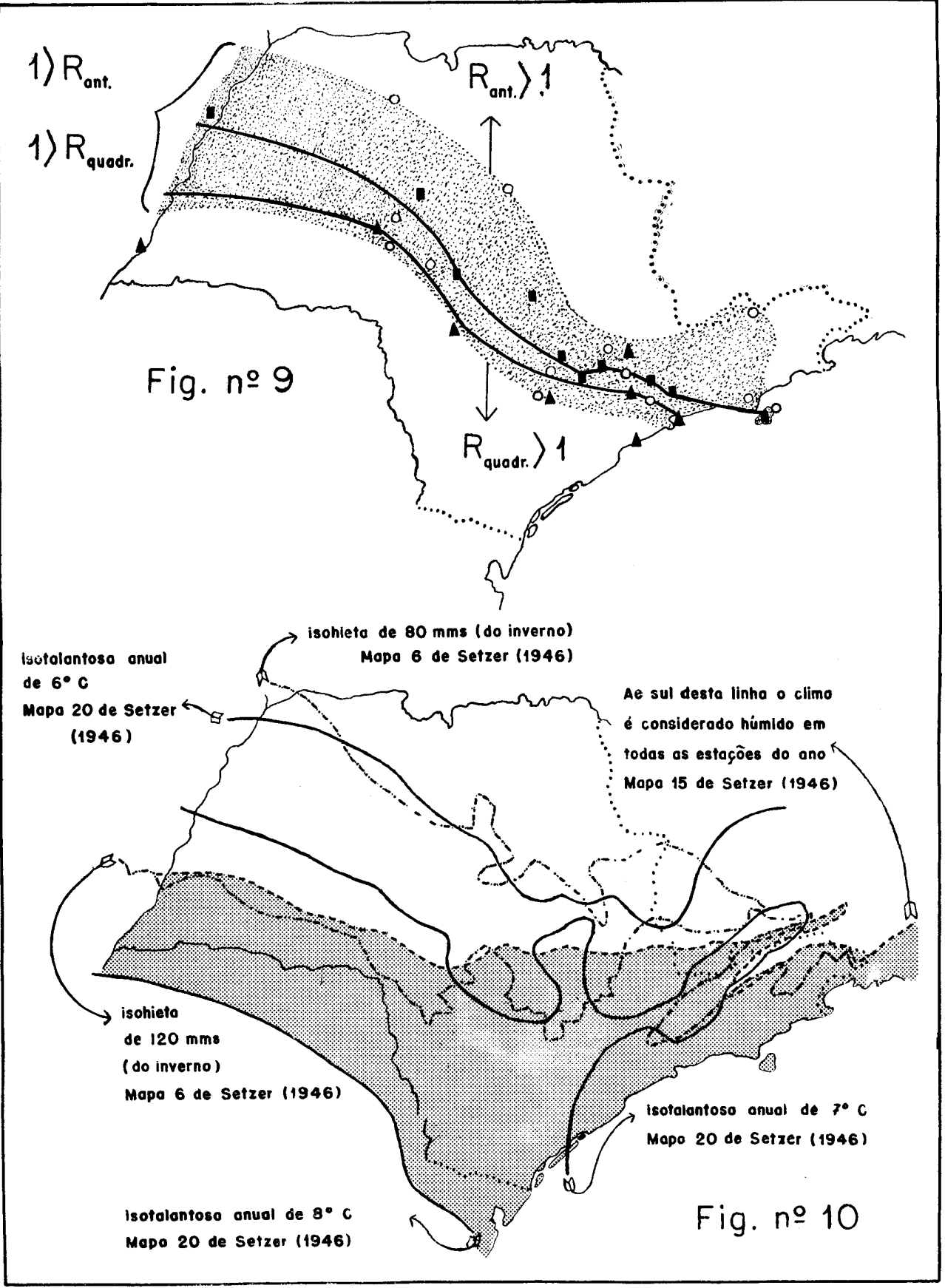




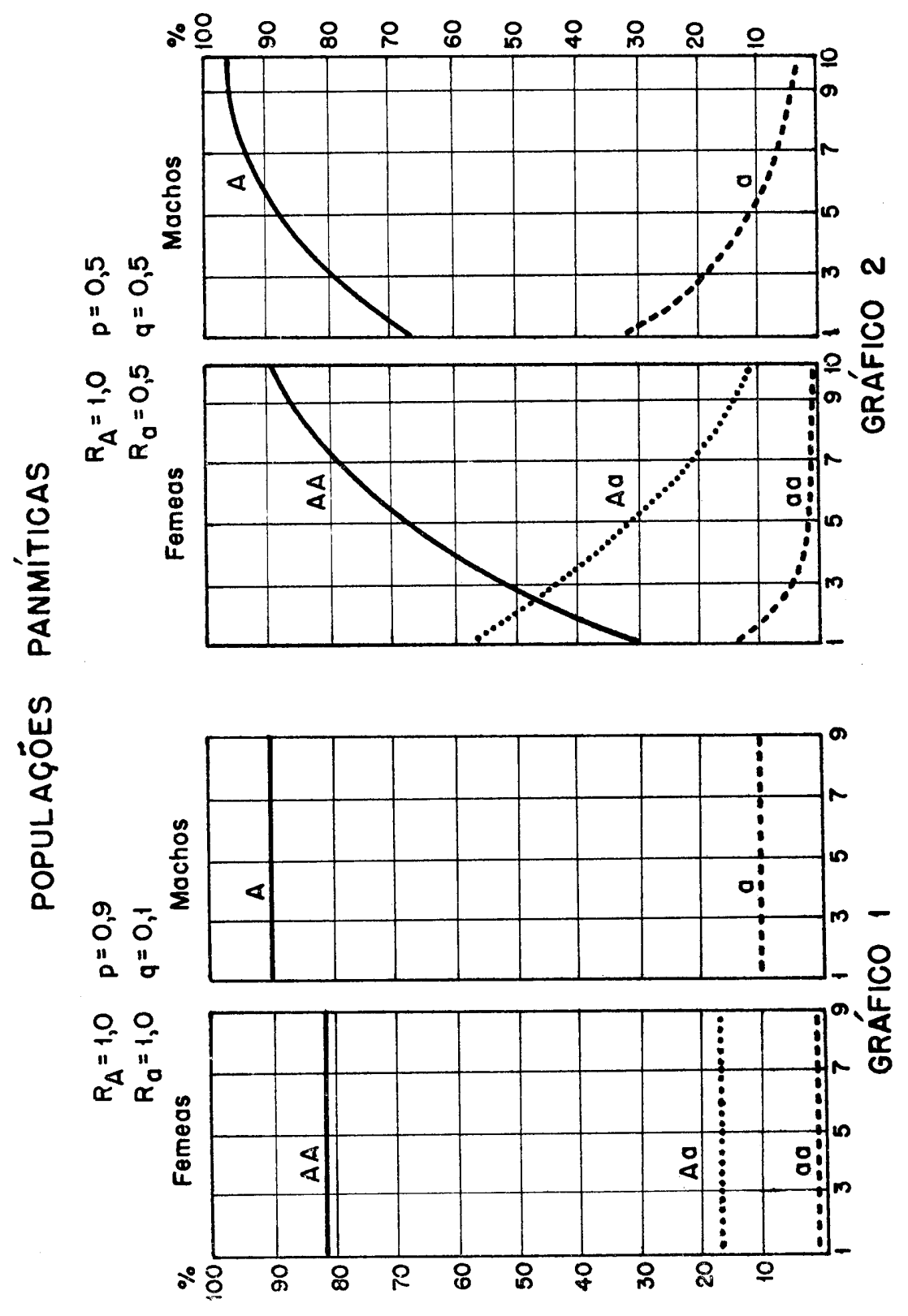




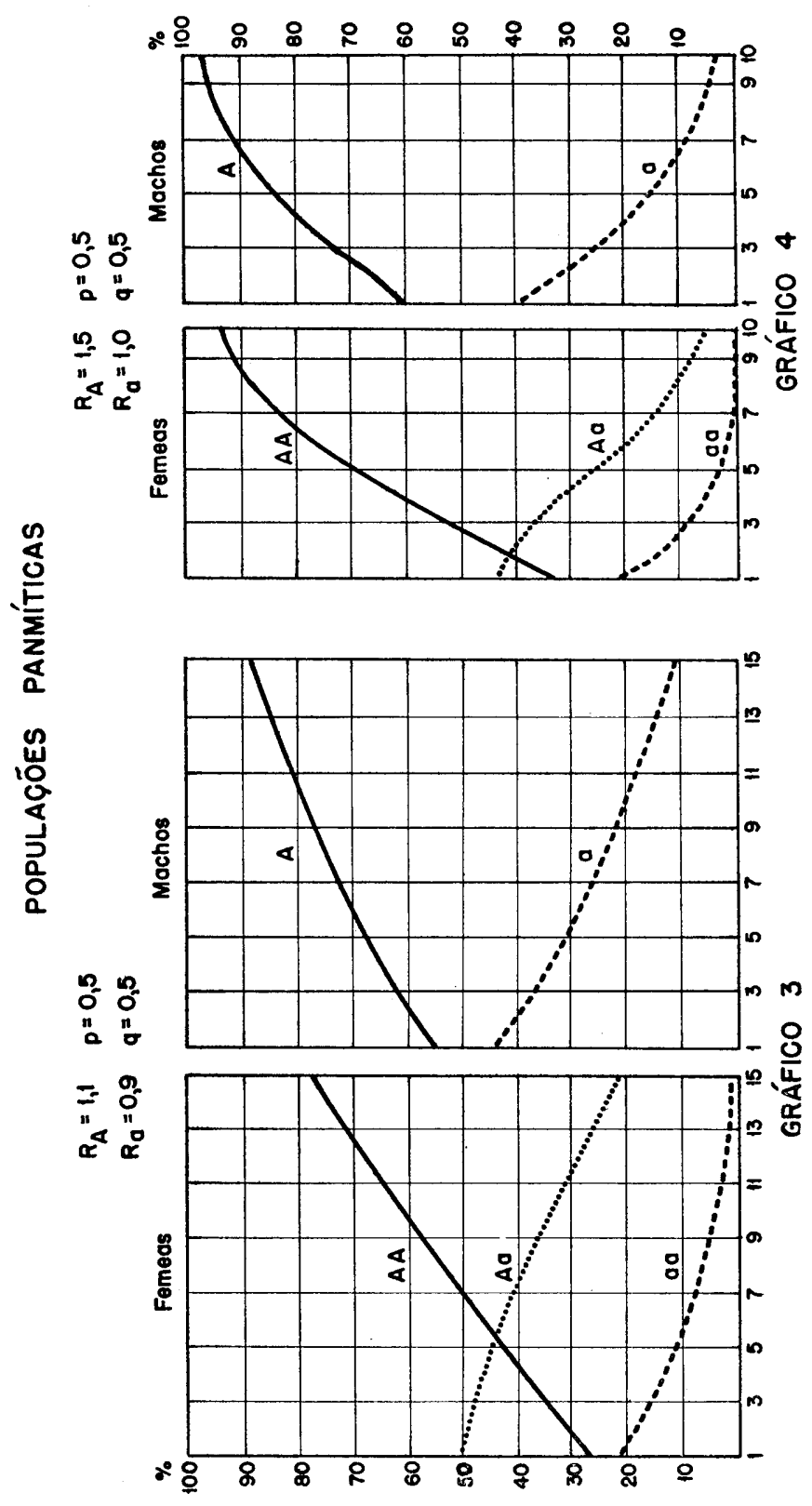




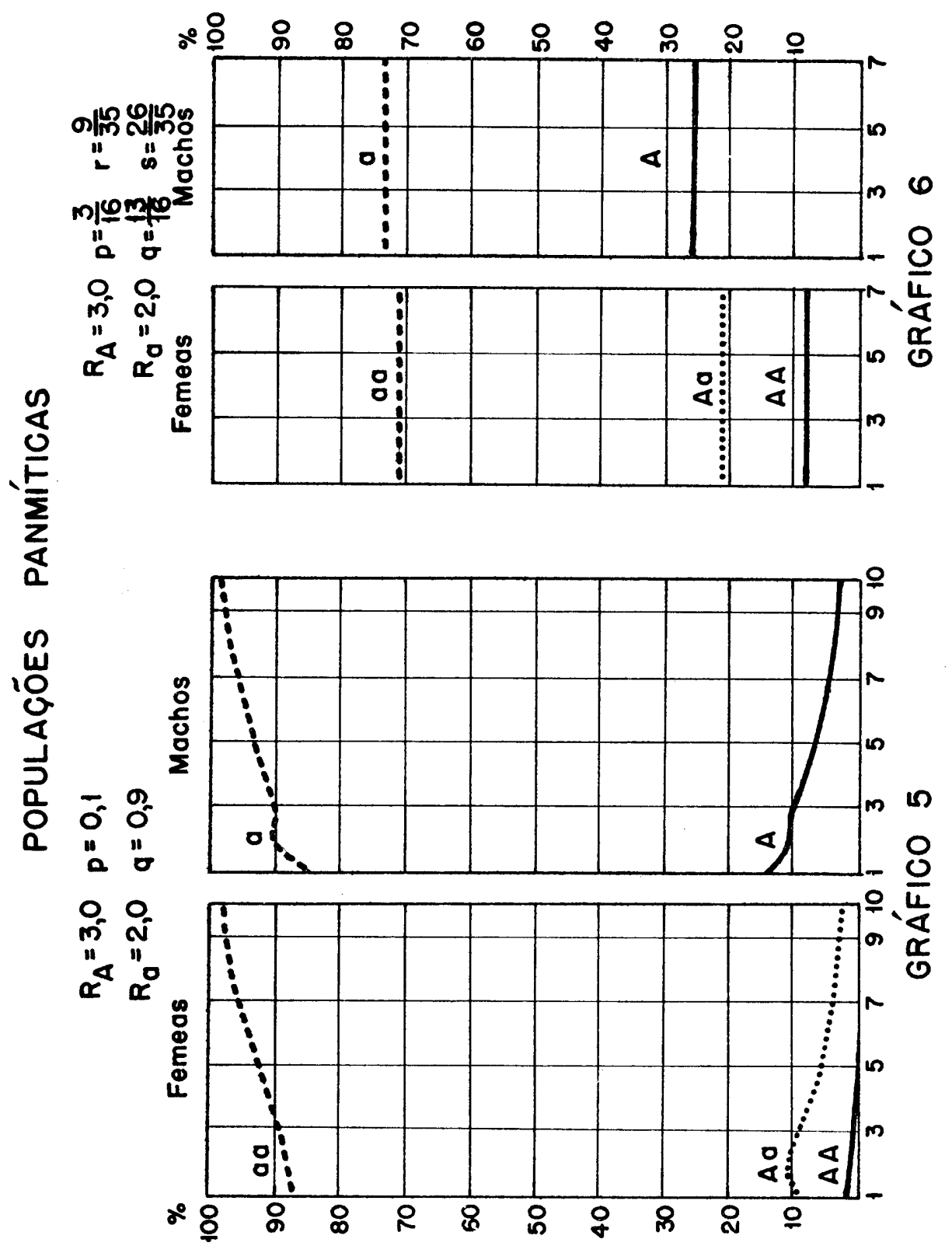




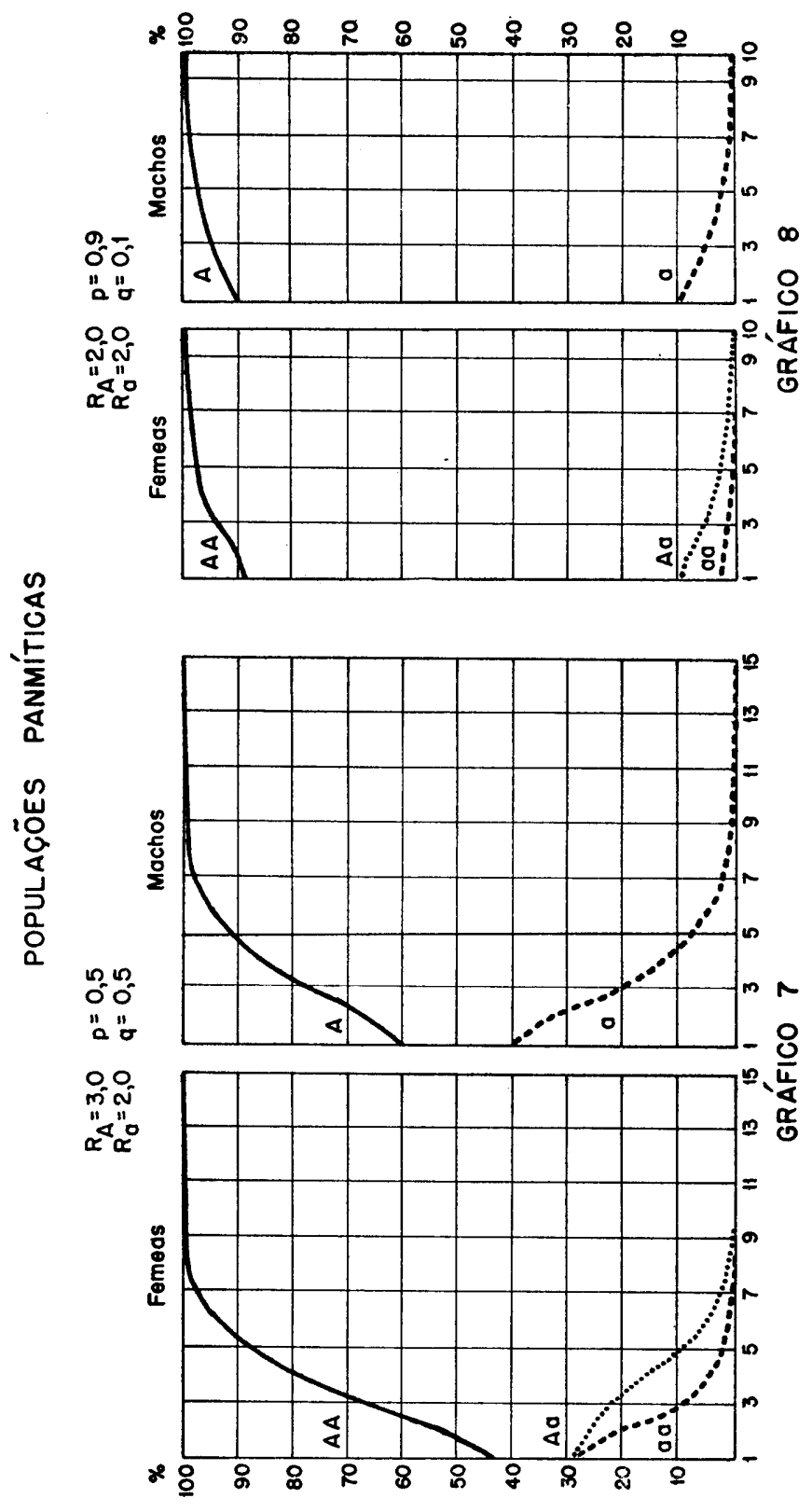




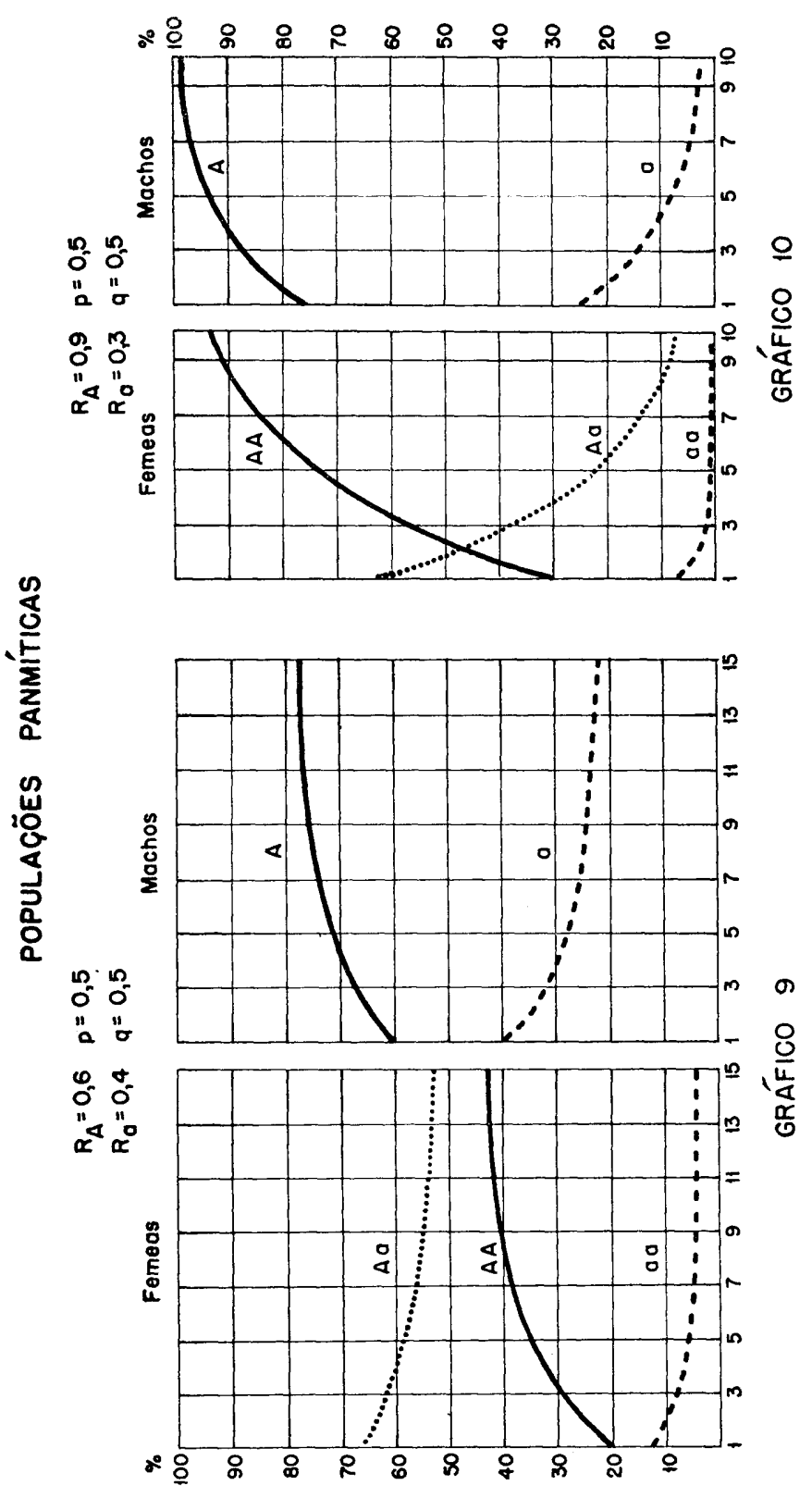




\section{POPULAÇOEES ENDOGÄMICAS}

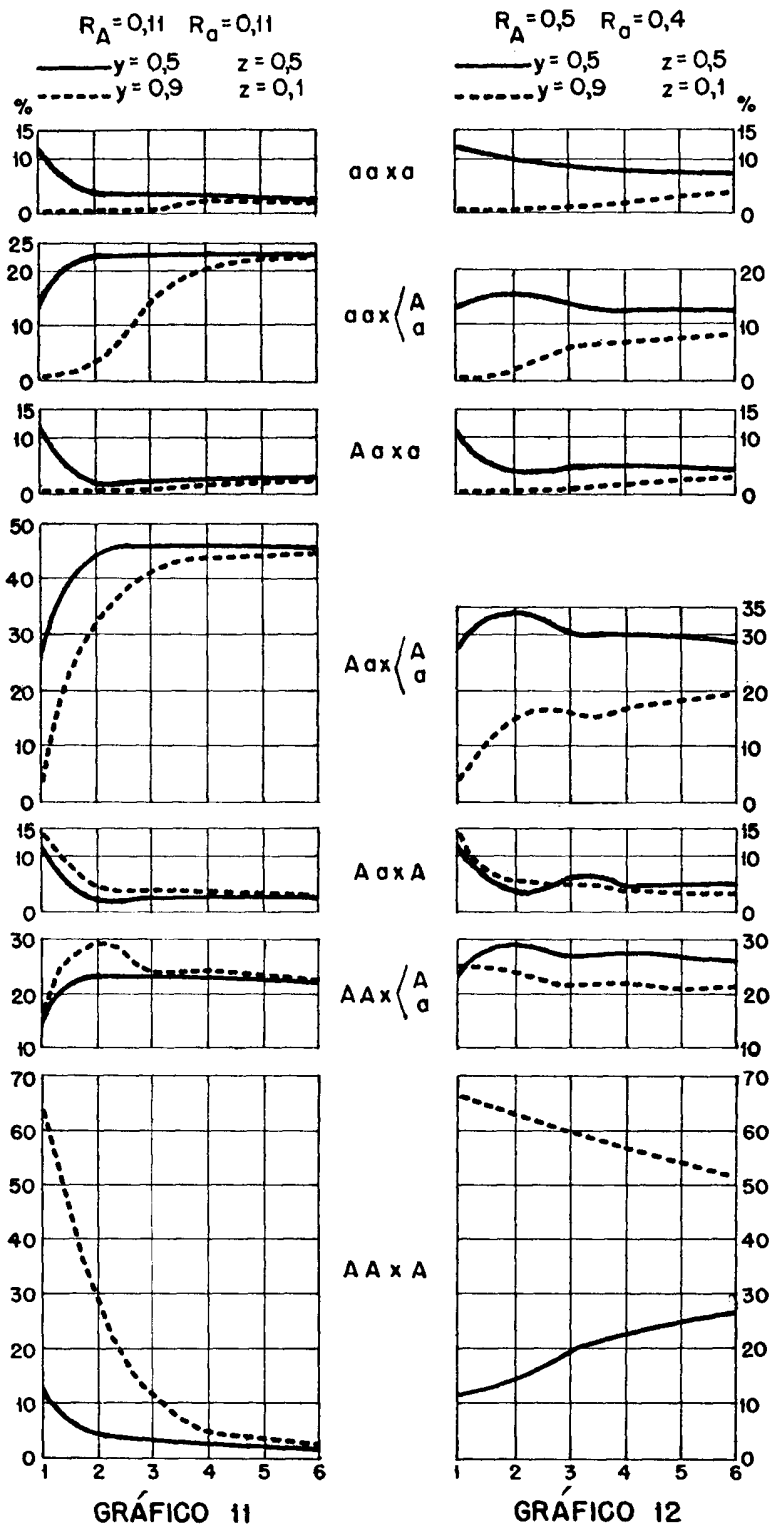


POPULAÇŌES ENDOGÂMICAS

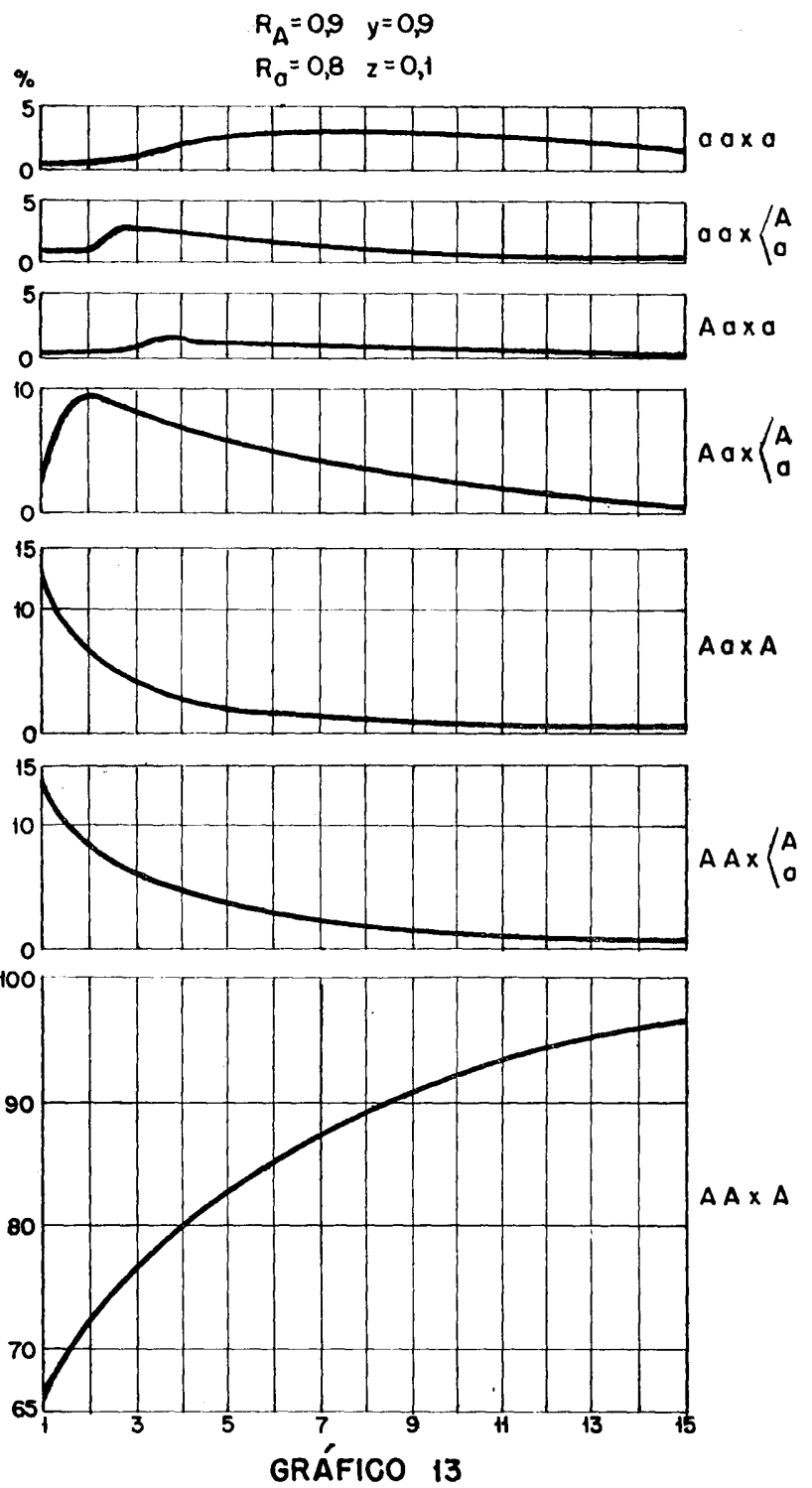


POPULAÇÕES ENDOGÂMICAS

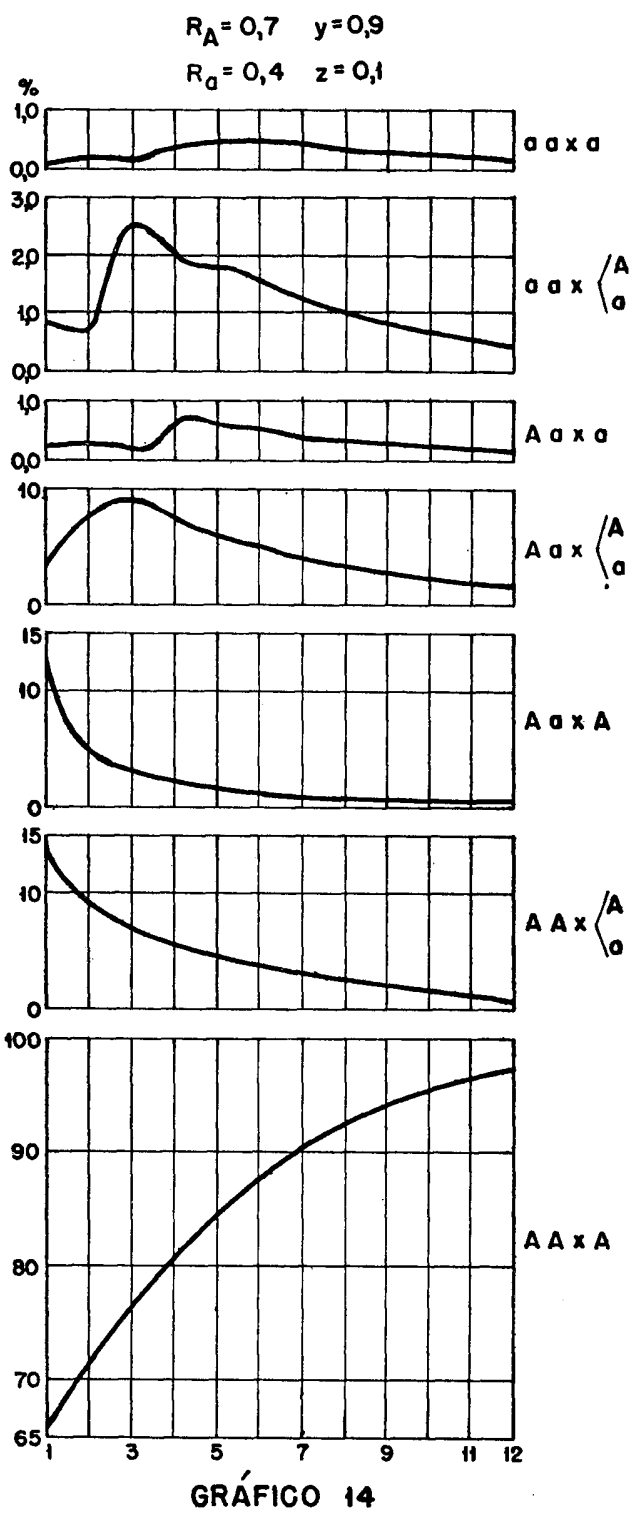


be expected in an aproximately pure line. Journ. Gen., 32: 375-391.

1937a - Some theoretical aspects of continued brothersister manting. Journ. Gen., 34: 265-274.

- $-1937 \mathrm{~b}$ - The effect of variation in fittness. An. Nat., 71: $337-349$.

HALDANE, J. B. S. e C. H. WADDINGTON - 1931 - Inbreeding and linkage. Genetics, 16: 357-374, July.

HAMBLETON, J. I. - 1947 - Gaz-treated virgin queens produce drones. Glean. B. Cult., 75 (10): 600-601, October.

HOGBEN, LANCELOT - 1946 - An Introduction tomathematical genetics. xii, 260 pgs., W. W. Norton and Company, Inc., New York.

IHERING, H. v. - 1903 - Biologia das abelhas melliferas do Brasil - Tradução de Rodolpho v. Ihering e Bruno Sampaio de Correia em 1930. Boletim de Agricultura, 31 (5 e 6) : 435-506, e 31 (7 e 8): 649-714, figs. 1-22.

KALMUS, H. e C. A. B. SMITH - 1948 - Production of pure lines in bees. Journ. Gen., 49 (2): 153-158,, October.

KEER, WARWICK E. - 1946 - Formação das castas no gênero Melipona (Illiger, 1806) - An. Esc. Sup. Agr. "Luiz de Queiroz", 3: 299-312, figs. 1-3.

- - 1947 - Estudos sôbre o gênero Melipona. i-iii, 1-67, 51 figs. Piracicaba.

- - 1948 - Estudos sôbre o gênero Melipona. An. Esc. Sup. Agr. "Luiz de Queiroz", 5: 181-276, 51 figs.

- 1950a - Evolution of the mechanism of caste determination in the genus Melipona. Evolution, 4 (1): 7-13.

- $-1950 \mathrm{~b}$ - Genetic determination of castes in the genus Melipona. Genetics, 35: 143-152, March.

KERR, WARWICK E. e WOLFGANG KRAUSER - 1950 Contribuição para o conhecimento da bionomia dos Meliponini. Fecundação da rainha em Melipona quadrifasciata Lep. (Hymenoptera, Apoidea). Dusenia, 1 (5) : 275-282.

KINSEY, A. C. - 1937 - An evolutionary analysis of insular and continental species. Proc. Nat. Acad. Sci., 23: 5-11. 
KOOPMAN, KARL F. - 1950 - Natural selection for reproductive isolation between Drosophila pseudoobscura and Drosophila persimilis. Evolution, 4 (2): 135-148.

LAIDLAW, HARRY H., Jr. - 1949 - New instruments for artificial insemination of queen bees. Am. B. Journ., 89 (12) : $566-567$.

MACKENSEN, OTTO - 1947 - Effect of carbon dioxide on initial oviposition of artificially inseminated and virgin queen bees. Jorn. Econ. Ent., 40 (3) : 344-349:

$-1948-A$ new syringe for the artificial insemination of queen bees. Am B. Journ., 88 (8): 412, August.

MAIDL, FRANZ - 1934 - Diedebensgewohnheiten und Instinkte der Staattenbildenden Insekten. pp. 316-317. Verl. v. F. Wagner, Wien.

MANNING, F. J. - 1948 - Sex-determinetion in the honey bee. 100 pgs. Stoke-on-Trent.

- 1949 - Sex-determination in the honey bee. The Microscope, May-June.

MARIANNO FILHO, JOSE' - 1910 - Sôbre os meios naturais de defesa das abelhas sem ferrão. Cha. e Qui., 1 (2): 50-53 e 2 (1) : 8-10.

MARTIN, ALBERT, Jr. - 1948 - Genetic evidence for speciation in Habrobracon juglandis Ashmead. Proc. Pennsylvavania Ac. Sc., 22: 64-67.

MAYR, E. - 1942 - Systematics and origin of species. xiv, 334 pgs. Columbia University Press. New York.

MIKHAILOFF, A. S. - 1931 - Uber die vererbung der weissawgigkeit bei der Honigbiene (Apis mellifera). Induktive Abstam v. Vererbugslehere, 59: 190-202.

MICHENER, C. D. - 1944 - Comparative external morphology, phylogeny and a classification of the bees (Hymenoptera). Bull. Am. Mus. Nat. Hist., 82 (6) : 151-326.

MICHENER, C. D. - 1946 - Notes on the habits of some Panamanian stingless bees (Hymenoptera, Apidae). Journ. New York Ent. Soc., 54: 179-197. 
MOURE, J. S., C. M. F. - 1946a - Meliponas do Brasil. Cha. e Qui., 74: 609-612.

- $-1946 \mathrm{~b}$ - Contribuição para o conhecimento dos Meliponinae (Hym., Apoidea). Rev. Ent., 17 (3): 437-443. senia, 1:

MOURE, J. S., C. M. F. e WARWICK E. KERR - 1950 - Sugestões para a modificação da sistemática do gênero Melipona - "Dusenia", 1 (2) : 105-129.

MULLER, F. 1874 - The habits of various insects. Nature (London), 10: 102-103.

MUNRO, J. A. - 1925 - Inheritance in the honey bee. Am. B. Journal, 65: 337-338 (Ap. Nolan, 1937).

NACHTSCHEIM, H. - 1913 - Cytologische Studien über die Alipio Miranda Ribeiro. Em impressão.

Geschlechtsbestimmung bei der. Hhonigbiene (Apis mellifica L.). Arch. f. Zellf., 11: 169-241.

NOGUEIRA NETO, PAULO - 1948 - Notas bionómicas sôbre os Meliponineos (Hymenoptera, Apoidea). III. A enxameagem. Rev. do Museu Nacional, Volume em homenagem a - - 1949 - Notas bionómicas sôbre Meliponineos (Hymenoptera, Apoidea). II. Sôbre a pilhagem. Papais Avulsos Dep. Zol., 9 (2) : 13-32, figs. 1-2.

NOLAN, W. J. - 1937 - Bee Breeding. Yearbook of Agriculture, U.S.D.A., pgs. 1396-1418.

PACKARD, A. S., Jr. - 1869 - List of hymenopterous and lepidoterous insects collected by the Smithsonian expedition to South America, under Prof. James Orton. - An. Rept. Trustees Peabody Acad. Sc., Salem, Mass., (1): 56-57, 59.

PIMENTEL GOMES, FREDERICO - 1950a - Sôbre algumas equações de diferenças relacionadas com a genética de Populações. An. Esc. Sup. Agr. "Luiz de Queiroz", vol. 6. Em publicação.

- $-1950 \mathrm{~b}$ - Sôbre um sistema de equações relativas a um modêlo matemático de populações de himenópteros endogâmicos. (em impressão) . 
POLHEMUUS, MARTIN S., JAY L. LUSH and WALTER C. ROTHENBUHLER - 1950 - Mating sytems in honey bees. Journ. Hered., 41 (6) : 151-155, fig. 6-7.

POULTON,, E. B. - 1933) - Proctetive adaptations of animalsespecially insects (Discussion)., Proc. Ent. Soc. Lond. 7:79-105.

ROBERTS, WILLIAM C. - 1944 - Multiple mating of queenbees proved by progeny and flight tests. Gleanings in Bee Culture 72 (6): 255-259, 303.

- -1947 - A plastic syringe for artificial insemination of honey bees. Journ. Econ. Ent., 40 (3): 445-446.

ROOT, A. I. y E. R. ROOT - $1943-\mathrm{ABC}$ y XYZ de la Apicultura. Tradução de J. L. Mubany. Libreria Hachette S. A., Buenos Aires.

SANDERSON, A. R. and D. W. HALL, - 1948 - The citology of the honey bee, Apis mellifica L., Nature; 162: 34-35.

SCHMIEDER, RUDOLPH, G. - 1938 - The sex ratio in $M e-$ littobia chalybii ASHMEAD, gametogenesis and cleavage in females and in haploid males (Hymenoptera: Chalcidoidea). Biol. Bull. 74: 256-266.

SCHMIEDER, RUDOLPH, G. and P. W. WHITING - $1947-$ - Reproductive economy in the chalcidoid wasp Melittobia. Genetics, 32:29-37.

SCHWARZ, H. F. - 1932 - The genus Melipona. Bull. Amer. Mus. Nat. Hist., 63: 231-460, figs. 1-2, pls. 1-10.

- 1938 - The stingless bees (Meliponidae) of British Guiana and some related forms. Bull. Am. Mus. Nat. Hist., 74: 437-508.

Bull. Am. Mus. Nat. Hist., 76: 83-141, figs. 1-16.

- - 1948 - Stingless bees (Meliponidae) of the Western Hemisphere. Bull. Am. Mus. Nat. Hist., 90: i - xviii, 1-546, figuras esquemáticas 1-87, estampas 1-8, táboas 1-5.

SETZER, JOSE' - 1946 - Contribuição para o estudo do clima do Estado de São Paulo. Separata do Boletim D.E.R., Vols. 9 a 11, pgs. 1-239. 
SHOEMAKER, HUST - 1947 - Multiplo mating in the queen honeybee. Am. B. Journ., 87 (1): 19.

SMITH, G. S. - 1941 - A new form of spruce sawfly identified by means of its citology and parthenogenesis. Sc. Agr., 21 (5) : 245-305.

STREISINGER, GEORGE - 1948 - Experiments on sexual isolation in Drosophila. IX. Behavior of males with etherized females. Evolution, 2 (2) : 187-188.

STUCKI, H. - 1936 - Hat uns das Aderbild des Bienenflügels wichtiges zu Sagen ? Schweiz. Bienen-Ztg., 59: 37-40.

THOMPSON, A. V. - 1948 - Carniolans vs. leather-colored Italians - a study in production. Gleanings in Bee Culture, 76 (1): 10-11.

WATSON, L. R. - 1927a - Controlled mating in honeybees. 50 pgs., Hamilton, Illinois.

- $-1927 \mathrm{~b}$ - Controlled mating in tho honeybee. Iowa State Apiarist Rept., 1927: 36-41.

- 1928 - Controlled mantig in honeybee. Quart. Rev. Biol., 3 (3) : 376-390.

WHITE, M. J. D. - 1945 - Animal cytology and Evolution. viii, 375 figs. University Press, Cambridge.

WHITING, P. W. - 1940 - Multiples alleles in sex-determination of Habrobracon. Journ. Morph., 66: 323-355.

- -1947 - Some experiments with Melittobia and other wasps. Journ. Hered., 38 (1) : 11-20, figs. 6-9.

WINGE, O. - 1934 - The experimental alteration of sex chromosomes into autosomes and vice-versa, as illustrated by Lebistes. Compt. Rend. Trav. Lab. Calsberg, 21 (1): 1-50.

WRIGHT, SEWALL - 1931 - Evolution in mendelian populations. Genetics, 16: 97-159.

114-138.

WRIGHT, SEWALL and THEODOSIUS DOBZHANSKY 1946 - Genetic of natural populations. XII. Experimental 
reproduction of some of the changes caused by natural selection in certain populations of Drosophila peseudobscura. Genetics, 31 (2): 125-256.

\section{EXPLICAÇÃO DAS FIGURAS}

Fig. 1-Esquema de populações com reprodução por cruzamento entre mãe e filho (redesenhada de Kalmus e Smith, 1948).

Fig.2 - Esquema de populações com reprodução por cruzamento entre irmão e irmã (redesenhada de Kalmus e Smith, 1948).

Fig. 3-Esquema de populações com reprodução por cruzamento entre tia e sobrinho (redesenhada de Kalmus e Smith, 1948).

Fig. 4-Orifício de entrada de uma colónia de $M$. quadrifasciata anthidioides LEP., mostrando as formações de barro e dejecções que servem para confundi-la com defeitos da casca da árvore, após ser infeccionada com organismos vegetais.

Fig. 5- Ninho de Trigona (Partamona) testacea helleri FRIE$\mathrm{SE}$, disfarçado entre bromeliaceas. (Figura 13 de Ihering, 1903, reedição de 1930 , pg. 485).

Fig. 6-Esquema da asa anterior de Apis mellifera LINNAEUS, segundo a fig. 1 de Castel e Phillips 1903, pg. 20.

Fig. 7-Mapa da América do Sul mostrando a distribuição geográfica da espécie Melipona quadrifasciata LEP. As 4 linhas grossas foram executadas passando por localidades onde constatámos a não existência da dita espécie.

Fig. 8- Mapa do Estado de São Paulo e regiões vizinhas mostrando, com mais detalhe, a zona em que se encontram os híbridos naturais entre as subespécies Melipona quadrifasciata anthidioides LEP. e Melipona quadrifasciata quadrifasciata LEP. 
Fig. 9-Esquema do Estado de São Paulo com a zona de hibridação demarcada.

Fig. 10 - Esquema do Estado de São Paulo mostrando as isotalantosas anuais de $6^{\circ} \mathrm{C}, 7^{\circ} \mathrm{C}$ e $8^{\circ} \mathrm{C}$, as isohietas do inverno, de 80 e $120 \mathrm{mms}$., e a linha do sul da qual o clima é considerado úmido em tôdas as estações do ano. Segundo Setzer (1946) mapas 6, 15 e 20.

\section{EXPLICAÇÃO DOS GRAFICOS}

Os Gráficos 1 a 10 representam as frequências relativas de um par de aléles durante sucessivas gerações de uma população panmítica de himenópteros. Para êstes gráficos, foram desconsideradas as migrações e mutações. A frequência dos genotipos das fêmeas foi colocada á direita e a dos machos á esquerda; essa separação tornou-se necessária em virtude de os machos serem haploides e exibirem dois genotipos ( $\mathrm{A}$ e a) e as fêmeas diploides com três genotipos ( $\mathrm{AA}, \mathrm{Aa}$ e aa). No eixo vertical colocámos o número de ordem das sucessivas gerações. Usamos para todas as curvas a seguinte notação; linha cheia - para os genotipos AA e A, linha pontilhada - para o heterozigoto Aa, e linha interrompida - para os genotipos aa e a. As populações estão representadas nos gráficos com suas frequências obtidas após a seleção. Assim, para calcular o equilíbrio não podemos usar a equação :

q $q=\mathrm{p}^{2}(\mathrm{AA})+2 \mathrm{pq}(\mathrm{Aa})+\mathrm{q}^{2}(\mathrm{aa}) ; \delta^{\pi}=\mathrm{r}(\mathrm{A})+\mathrm{s}(\mathrm{a})$, mas sim a equação :

$$
\begin{array}{r}
q q=\operatorname{prRA}(\mathrm{A})+[\mathrm{ps}+\mathrm{qr}\rceil(\mathrm{Aa})+\mathrm{qsRa}(\mathrm{aa}) ; \sigma^{\top} \sigma^{\star} \\
=\mathrm{pRA}(\mathrm{A})+\mathrm{qRa}(\mathrm{a})
\end{array}
$$

Gráfico 1-Gens neutros. Verifica-se que a frequência final é igual a frequência inicial.

Os gráficos 2 a 4 referem-se a gens subviáveis ou superviáveis, recessivos, intermediárias ou dominantes, conforme o mutante seja o gen $a$ ou $A$.

Gráfico 2-O valor de sobrevivência dos genotipos $A A$ e $A$ é igual ao heterozigoto $(\mathrm{RA}=1)$ e o do gen $a$ é $R a=0,5$. 
Qualquer que seja a frequência inicial do gen menos viável (diferente de $100 \%$ ), será eliminado.

Gráfico 3-O valor de sobrevivência do aléle $A$ é maior que 1 e do aléle $a$ menor que 1 . Como no gráfico anterior, o gen mais viável eliminará o seu aléle, qualquer que seja a sua frequência inicial.

Gráfico 4-O valor de sobrevivência do gen mais viável é $R A=1,5$ e a do seu aléle é $R a=1$. Observa-se a rápida eliminação do gen $a$.

Os gráficos 5 a 8 referem-se a gens de isolamento.

Gráfico 5-O heterozigoto $A a$ é menos viável que os demais genotipos. Para os valores de sobrevivência $R A \equiv 3 \mathrm{e}$ $\mathrm{Ra}=2$ o equilíbrio seria alcançado sòmente se a proporção entre os gens, desde o início, fôr :

$$
\mathrm{p}=\frac{3}{16}, \mathrm{q}=\frac{13}{16} ; \mathrm{r}=\frac{9}{35} \text { e } \mathrm{s}=\frac{26}{35} .
$$

Como nêste gráfico 5 a frequência do gen $A$ está abaixo do equilíbrio $(\mathrm{p}=0,1)$ observa-se que, mesmo sendo mais viável, será eliminado.

Gráfico 6-Mesmo valores de sobrevivência que no gráfico 5, porém todos os genotipos possuem suas frequências iguais às frequências do equilíbrio. Enquanto essa condição fôr mantida todos os aléles permanecerão na população. Tal condição só poderá existir na natureza em regiões limítrofes entre duas subspécies.

Gráfico 7 - Os valores de sobrevivência são iguais aos do Gráfico 5 , porém a frequência inicial do aléle $a$ está abaixo do ponto de equilíbrio. Verifica-se a rápida eliminação do dito gen.

Gráfico-8 Este gráfico ilustra o caso particular de gens de isolamento com o mesmo valor de sobrevivência. O equilíbrio teórico é obtido sòmente quando há na população, desde o início, $50 \%$ de cada aléle. Desde que um seja mais frequente que o outro, como supuzemos aquí para o gen $A$, o outro será eliminado. 
Os gráficos 9 e 10 representam a variação da frequência sofrida por um pạ de aléles heteróticos em sucessivas gerações.

Gráfico 9-Ilustra o caso em que os valores de sobrevivência de ambos aléles são inferiores a 1 (gens heteróticos) porém não diferem além do permitido pela fórmula 11. Com os valores de sobrevivência $R A=0,60$ e $R a=0,40$ o equilíbrio será alcançado quando tivermos uma população com as seguintes frequências relativas entre seus genotipos:

$$
\begin{aligned}
q O & =45,04 \%(\mathrm{AA})+51,56 \%(\mathrm{Aa})+3,40 \%(\mathrm{aa}) \\
& =78,46 \%(\mathrm{~A})+21,54(\mathrm{a}) .
\end{aligned}
$$

Gráfico 10 - Ilustra o caso de gens heteróticos que diferem entre si mais do que o permïte a fórmula 11. Taís gens não contribuem para originar espécies polimórficas entre os Hymenoptera, pois o de maior valor de sobrevivência suplantará seu aléle. Nếste easo o valor máximó que RA poderia ter quando $\mathrm{Ra}=0,30$ seria $\mathrm{RA}=0,71$. Como fizemos $\mathbf{R A}=0,90$ verificamos qué o gen a será eliminado rápidamente da população.

Os gráficos 11 a 14 representam as frequências relativás entre os diversos tipos de cruzamento possiveis quandô existe em uma população himenópteros endogâmicos um par de aléles $A$ e a. O sistema de endogamia esquematizado nesses gráfićos foi o de acasalamento entre irmãos; por ser um dos poucos sistemas que existe na natureza. No eixó hórizontal colocámós o número de ordem das sucessivas geraçôes, e no èixo vertical as frequências relativas em porcentagens: Para não embaralhar o gráfico com muitas curvas colocámos cada curva, correspondente a um determinado tipo de cruzamento, em um l retângulo quadriculado, escrevendo á sua direita, fora do gráfico, o tipo de cruzamento, ao qual essa curva corresponde A única excepção a êsse sistema é o gráfico 12 , onde para economia de espaço eserevemos os tipos de cruzamento á esquerda ou seja os gráficos 11 e 12, para servir a ambos. Comb vemos no III capítulo da 1a. parte denominamos as frequências dos diversos tipos de cruzamento por pn, qn, rn, sn, tn, un, e vn. Para dar uma idéia mais objetiva da frequência de cada gen na população usamos as letras y e $z$, onde y é a frequência inicial do gen $A$ e corresponde a fórmula : 


$$
\mathrm{y}=\mathrm{pn}+\mathrm{qn}+\frac{1}{2}(\mathrm{rn}+\mathrm{sn}+\mathrm{tn}),
$$

e z é a frequência inicial do gen $a$ e corresponde a fórmula :

$$
\mathrm{q}=\mathrm{vn}+\mathrm{un}+\frac{1}{2}(\mathrm{rn}+\mathrm{sn}+\mathrm{tn}) .
$$

Gráfico 11 - Gens heteróticos. Tanto RA como Ra são iguais a 0,11 , e as frequências que deverão ser atingidas no equilíbrio acham-se escritas no Quadro II. Para melhor ilustrar a tendência de aproximar-se rápidamente ao equilíbrio utilizámos duas frequencias iniciais, sendo uma representada por linhas cheias e outras por linhas interrompidas.

Gráfico 12 - Também nêste gráfico temos um par de aléles heteróticos, porém RA não é igual a $\mathrm{Ra}$ como no Gráfico 11 , mas diferem dentro dos limites permitidos pela fórmula 3,09 de Pimentel Gomes (pg. )) e são ambos inferiores a 0,75 . Verifica-se que, tanto em uma (linhas cheias) como em outra (linhas interrompidas) frequência inicial que usámos, a população tende para um equilíbrio com todos os tipos de cruzamento presentes.

Gráfico 13 - Os índices de sobrevivência, $\mathrm{RA}=0,9, \mathrm{Ra}=0,8$, diferem menos entre si do que os índices do Gráfico 12 , porém são superiores ao limite 0,75 . Verifica-se que a classe dos heterozigotos diminue rápidamente e que o resultado final será uma população pura para o gen A.

Gráfico 14 - Ilustra o caso em que os índices de sobrevivência são inferiores a 0,75 porém, diferem mais entre si do que o permite a fórmula 3,09 (pg. . ). Para um índices $\mathrm{Ra}=0,4$, como o dêste gráfico, o valor máximo permitido pela fórmula para RA é 0,54 . Verifica-se que com $R A=0,7$ o gen menos viável será eliminado rápidamente da população. 


\section{Quadro I- Himenópteros endogâmicos}

\begin{tabular}{|c|c|c|c|c|c|c|c|}
\hline Q & \multicolumn{2}{|c|}{$\mathrm{AA}$} & \multicolumn{3}{|c|}{$\mathrm{Aa}$} & \multicolumn{2}{|c|}{$a a$} \\
\hline 0 & A & Aea & A & Aea & $a$ & Aea & $a$ \\
\hline$P_{t}$ & & $\frac{1}{4}$ & & $-\frac{2}{4}$ & & $\frac{1}{4}$ & \\
\hline$P_{2}$ & $\frac{1}{8}$ & $\frac{1}{8}$ & $\frac{1}{8}$ & - & $<\frac{1}{8}$ & & $\frac{1}{8}$ \\
\hline$P_{3}$ & 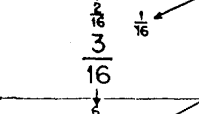 & $\frac{2}{16}{ }^{k^{2}}$ & $\frac{1}{16}$ & $\underbrace{\frac{1}{6}} \frac{4^{6}}{16}$ & $<\frac{1}{16} \underbrace{\frac{10}{16}}$ & $C_{10}^{\frac{10}{60}} \frac{2}{16}$ & {$\left[\begin{array}{ll}\frac{1}{3} \\
\frac{3}{16}\end{array}\right.$} \\
\hline$P_{4}$ & 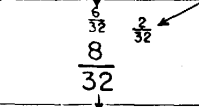 & $\frac{3^{32}}{\mathrm{kn}^{2}}$ & $\frac{2}{32}$ & 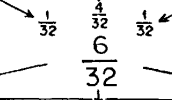 & $\sum^{\frac{2}{32}}$ & $\frac{3}{32}$ & 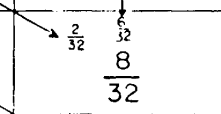 \\
\hline$P_{5}$ & $\frac{19}{64}$ & $\frac{5^{\frac{z^{2}}{60}}}{64}$ & $\frac{3}{64}$ & $=$ & $\frac{3}{64}^{{ }^{20}}$ & $\frac{5}{64}$ & ${ }^{\circ} \frac{10}{64}$ \\
\hline$P_{6}$ & 年 $\frac{43}{128}$ & $\frac{8}{128}$ & $\frac{5}{128}$ & $\frac{16}{128}$ & $\frac{5}{128}$ & $\frac{8}{128}$ & $\frac{43}{128}$ \\
\hline$P_{7}$ & $\frac{94}{256}$ & $\frac{13}{256}$ & $\frac{8}{256}$ & $\frac{26}{256}$ & $\frac{8}{256}$ & $\frac{13}{256}$ & $\frac{94}{256}$ \\
\hline$P_{8}$ & $\frac{201}{512}$ & $\frac{21}{512}$ & $\frac{13}{512}$ & $\frac{42}{512}$ & $\frac{13}{512}$ & $\frac{21}{5: 2}$ & $\frac{201}{512}$ \\
\hline$P_{n}$ & 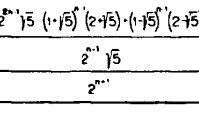 & 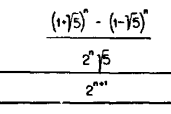 & 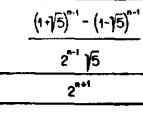 & 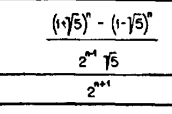 & 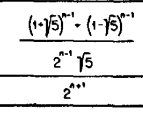 & 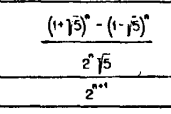 & 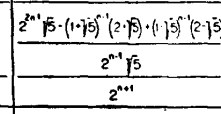 \\
\hline$P_{\infty}$ & $\frac{1}{2}$ & $\circ$ & 0 & $\circ$ & 0 & o & $\frac{1}{2}$ \\
\hline
\end{tabular}




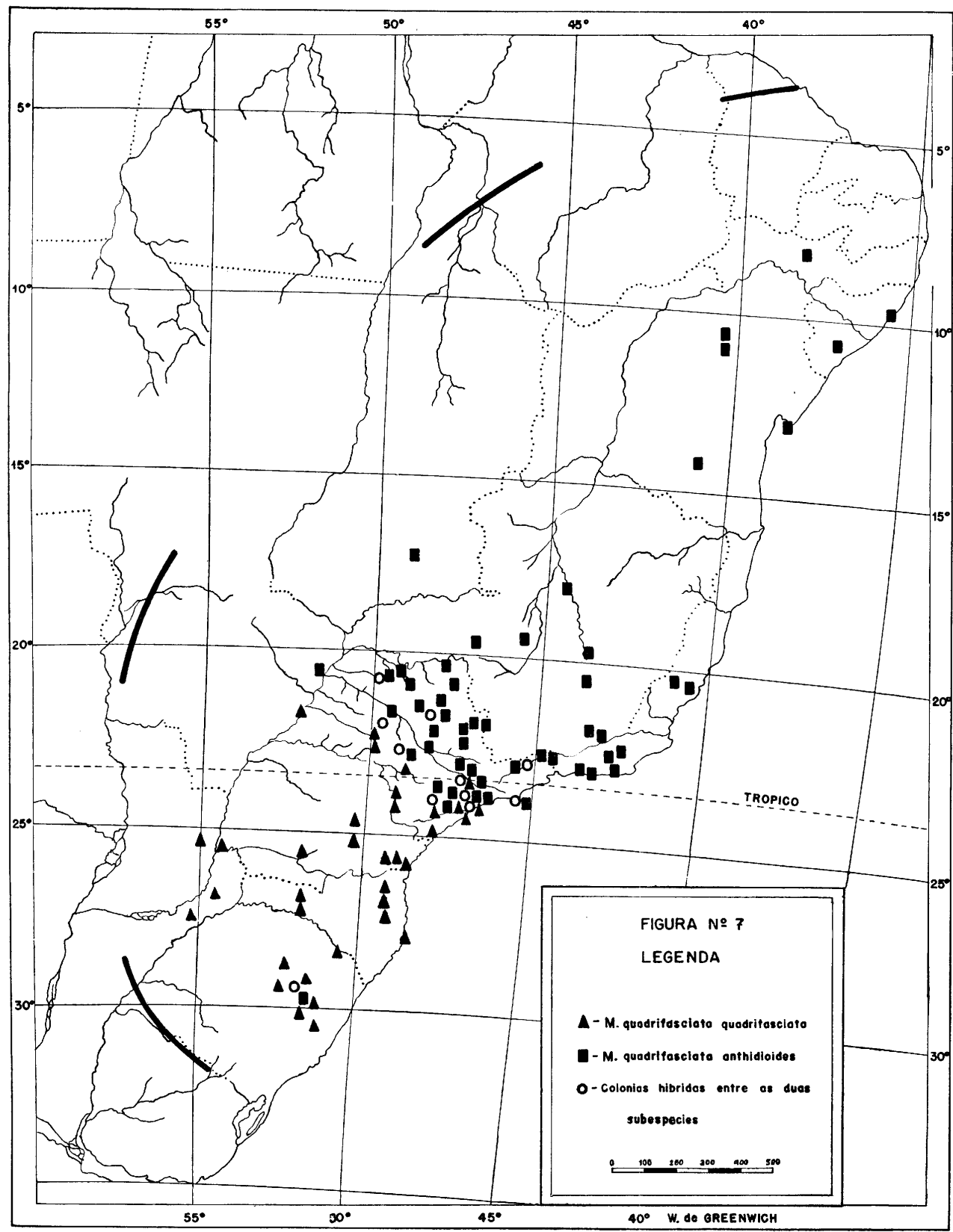




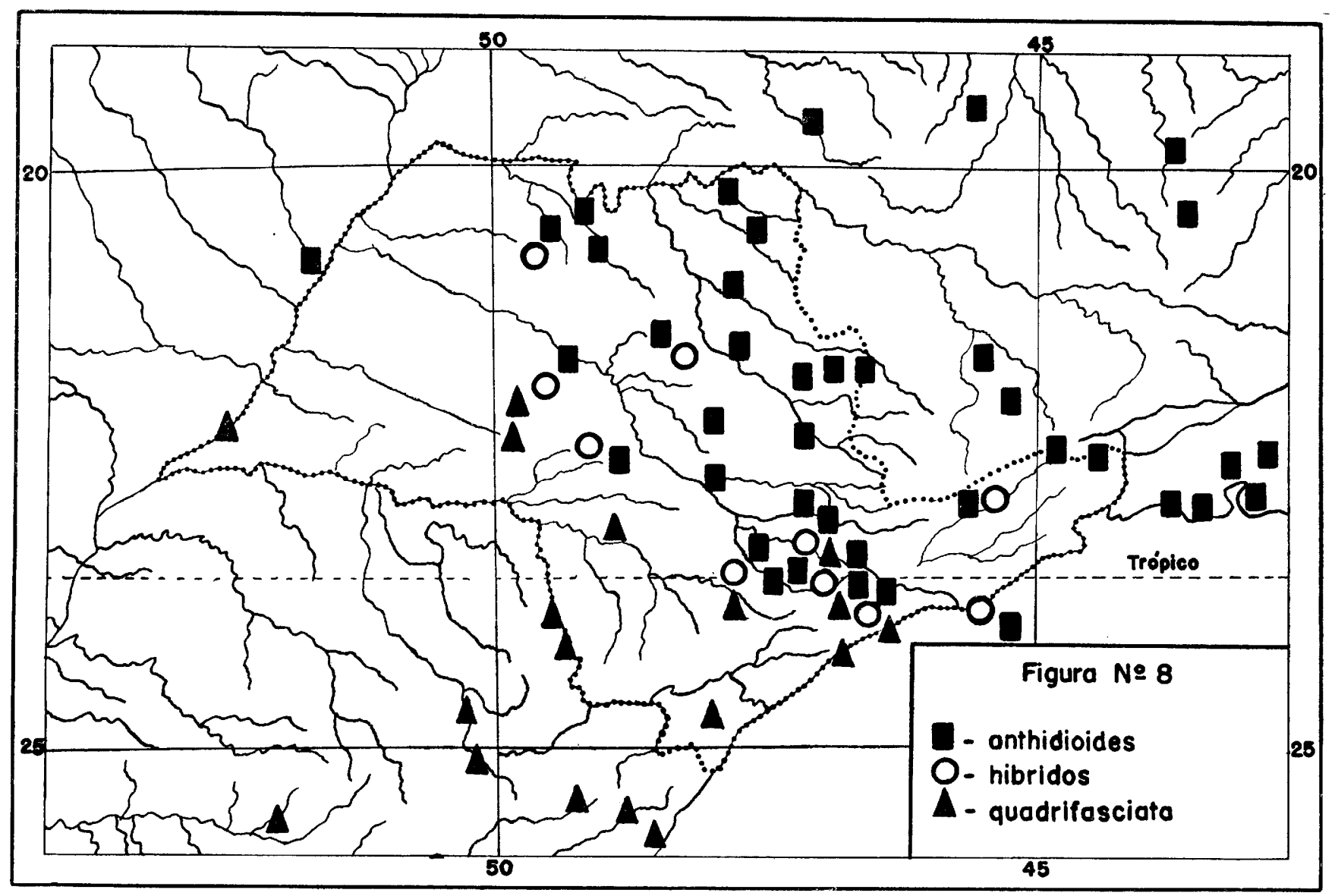




\section{ER R A T A}

Warwick Estevam Kerr,

An. E. S. A. "Luiz de Queiroz", $8: 219-354$

Devido ao fato de o autor ter estado em viagem de estudos pelos Estados Unidos durante o período em que as provas dêste trabalho ficaram prontas, um certo número de enganos foi impresso, o que conta pelo tamanho desusado desta errata. Mesmo assim, não serão mencionados enganos gráficos, quer no texto em português como no sumário em inglês, por serem fàcilmente dicerníveis pelo leitor.

\begin{tabular}{lll}
\hline Pág. Linha ONDE SE LE LEIA-SE \\
\hline
\end{tabular}

$273 \quad 17$

Apidade

Apidae

233

$2 \frac{2 p \cdot R_{A} R_{A}^{\prime}+q\left(R_{A}^{\prime}+R_{d}^{\prime}\right)}{2 q \cdot R_{0} R_{0}^{\prime}+q\left(R_{A}^{\prime}+R_{0}^{\prime}\right)}=1$

$$
\frac{2 p \cdot R_{A} R_{A}^{\prime}+q\left(R_{A}^{\prime}+R_{a}^{\prime}\right)}{2 q \cdot R_{a} R_{a}^{\prime}+p\left(R_{A}^{\prime}+R_{a}^{\prime}\right)}=1
$$

$235 \quad 29$

$S(a) \frac{26}{35}$

239

$$
6 \quad P=\frac{1-R_{A}}{2-R_{a}-R_{A}}
$$

$241 \quad 14$

espermatica

242

$$
3 \quad R_{v}=R_{v}^{3}+t^{\prime}(10)
$$

246

26

$$
\frac{2^{\left(2^{n-1)}\right.} \sqrt{5}(1+\sqrt{5})^{n}(2+\sqrt{5}) \cdot(1+\cdot \sqrt{5})^{n}(2 \cdot \sqrt{5})}{2^{2^{n}} \sqrt{5}}(17) .
$$

246

$$
27=\frac{(1+\sqrt{5})^{n}-(1-\sqrt{5})^{n}}{2^{2^{n}} \sqrt{5}}(18)
$$

$24628=\frac{(1 \cdot \sqrt{5})^{n-1}-(1-\sqrt{5})^{n-1}}{2^{2^{n}} \sqrt{5}}(19)$ espermateca

$$
R_{v}=\left(R_{v_{3}}\right)^{\dagger}
$$

$$
\begin{gathered}
S(a)=\frac{26}{35} \\
D=\frac{1-R_{0}}{2-R_{a}-R_{A}}
\end{gathered}
$$

$\frac{2^{2 n-1} \sqrt{5}(1+\sqrt{5})^{n}(2 \cdot \sqrt{5}) \cdot(1-\sqrt{5})^{n}(2-\sqrt{5})}{2^{2 n} \sqrt{5}}(17)$

$=\frac{(1+\sqrt{5})^{n}-(1-\sqrt{5})^{n}}{2^{\sqrt[n]{n+1}} \sqrt{5}}(18)$

$=\frac{(1 \cdot \sqrt{5} \cdot)^{n-1}-(1-\sqrt{5})^{n-1}}{2^{2 n} \sqrt{5}}(19)$ 
Pág. Linha

$247 \quad 26$

$24920 \quad$ qn $+1=\frac{1}{2}$ qn etc. .

\section{LEIA-SE}

A"

250 entre as linhas 5 e 6 faltou o seguinte :

$$
f(x)=q_{1}+q_{2} x+q_{3} x^{2}+q_{4} x^{4}+\ldots \ldots
$$

logo tem - se

$-\frac{1}{2} x f(x)=-\frac{1}{2} q_{1} x-\frac{1}{2} q_{2} x^{2}-\frac{1}{2} q_{3} x^{3}-\ldots$.

e também :

$-\frac{1}{4} x f(x)=-\frac{1}{4} q_{1} x^{2}-\frac{1}{4} q_{2} x^{3}-\frac{1}{4} q_{3} x^{4}-\ldots$

Dêsses três resultados, obtem-se por adição:

250 entre as linhas 20 e 21 faltou um traço sob todo o polinômio, indicando que a linha 21 representa a soma das 18,19 e 20.

$25423 \quad \Sigma=\frac{a B^{2}}{2 r}(34) \quad \sum=\frac{q B^{2}}{2 r}(34)$

$257 \quad 7 \quad \therefore 2 \mathrm{~B}-2 \mathrm{R} 2=\mathrm{RU}$ $\therefore 2 \mathrm{~B}-2 \mathrm{R} 2=\mathrm{R}+\mathrm{R} \mathrm{U}$

$257 \quad 14 \quad \mathrm{R}=-\frac{-1+\mathrm{V} \overline{1+4 \mathrm{~B}}}{2}$ 2 (49) $\mathrm{R}=$ $-1 \pm V \overline{1+4 B}$

$257 \quad 17 \quad R=\frac{-1 \sqrt{1+4 B}}{2}$

$$
R=\frac{-1+\sqrt{1+4 B}}{2}
$$

259

$$
p=\frac{1}{2} \cdot \frac{-1+\sqrt{1+4 B}}{2(2-\sqrt{1-4 B}}(55)
$$

$$
p=\frac{1}{2} \cdot \frac{-1+\sqrt{1+4 B}}{2-\sqrt{1+4 B}} \text { (55) }
$$

$260 \quad 15 \quad \frac{1}{4,45} 0,22472$

$$
\frac{1}{4,45}=0,22472
$$


263

$$
\begin{aligned}
& \text { Substituir todos os valores entre as linhas } 7 \text { e } 13 \text { por : } \\
& \begin{array}{llll}
\mathrm{Ra}=0,00 & \mathrm{RA}=0,00 & \mathrm{Ra}=0,50 & \mathrm{RA}<0,61 \\
\mathrm{Ra}=0,10 & \mathrm{RA}<0,27 & \mathrm{Ra}=0,60 & \mathrm{RA}<0,67 \\
\mathrm{Ra}=0,20 & \mathrm{RA}<0,38 & \mathrm{Ra}=0,70 & \mathrm{RA}<0,73 \\
\mathrm{Ra}=0,30 & \mathrm{RA}<0,47 & \mathrm{Ra}=0,74 & \mathrm{RA}<0,75 \\
\mathrm{Ra}=0,40 & \mathrm{RA}<0,54 &
\end{array}
\end{aligned}
$$

$267 \quad 6 \quad 2-\mathrm{n}$

$267 \quad 7$

$267 \quad 10$

$267 \quad 18$

29

.287

17

$$
(1-2-n)
$$$$
(1-2-n) m
$$$$
(0,8090) \mathrm{n}
$$$$
(0,6830) \mathrm{n}
$$

2-n

$(1-2-n)$

$(1-2-n) m$

$(0,8090) \mathrm{n}$

$(0,6830) \mathrm{n}$

$297 \quad 41 \quad$ Eliminar tôda a linha

303

Linhas 23,33 a 39 e pág. 304, linhas 1 a 18 :

NOTA : Em 1951 o autor, em colaboração com Dr. H. Ris (Ris e Kerr, 1952) fizeram novas lâminas de Apis mellifcra L., uma parte colorida com Hematoxilina e outra con $x_{\perp}$ Feulgen e verificararn que o suposto cromosoma sexual não se colore ccm Feulgen, o que sugere não ser êle uma cromosoma, mas sim um corpúsculo cuja natureza será estudada futuramente. Tarnbém um trabalho recente de Rothenbuler et al. (1951) demonstrou que em uma linhagem de abelhas, os ginandromorfos eram produzidos por polispermia, sendo a parte masculina o produto do desenvolvimento do nucleo de espermatozoide. Esse fato também veio trazer mais uma incompatibilidade com a teoria de Manning.

$\begin{array}{rrrr}307 & 19 & 15 & 237 \text { e } 238 \\ 307 & 22 & 16 & 238 \\ 307 & 32 & 75 & 313 \\ 311 & 22 & \therefore \text { êrro }=5,66 & \therefore \text { êrro } \%=5,66 \\ 311 & 25 & \therefore \text { êrro }=1,46 & \therefore \text { êrro } \%=1,46 \\ 311 & 28 & \therefore \text { êrro }=16,44 & \therefore \text { êrro } \%=16,44 \\ 311 & 31 & \therefore \text { êrro }=6,98 & \therefore \text { êrro } \%=6,98\end{array}$


Entre as linhas 28 e 29 faltou o seguinte:

Essas fórmulas, todavia, aplicam-se sòmente para populações diploides, sendo que para as populações de himenópteros nos utilizaremos das fórmulas de Wright para gens ligados ao sexo (que seguem o mesmo esquema que os himenópteros) que são as seguintes :

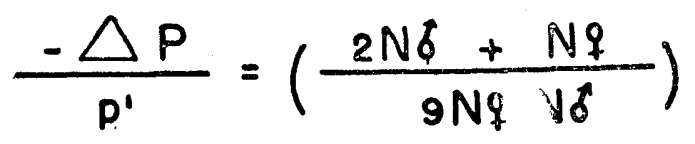

que para populações com igual números de femeas e machos torna-se

$$
-\frac{\Delta \mathrm{P}}{\mathrm{p}^{\prime}}=\frac{\mathrm{l}}{3 \mathrm{~N}}
$$

$323 \quad 30$ por ser mais exata :

por o número de $\delta^{\star} \delta^{\star}$ e $q ?$ nos Meliponini ser diferente :

$323 \quad 31$ substituir por :

$$
\frac{-\Delta P}{p^{\prime}}=\frac{2 \times 157,08+1,57}{9 \times 157,08 \times 1,57}=0,222
$$

$\begin{array}{lr}324 & 2 \\ 324 & 7 \\ 326 & 40 \\ 334 & 33\end{array}$

$$
7.39 \%
$$

$11.5 \%$

Iherdig
$22,2 \%$

$23, \%$

Ihering

$335 \quad 30$

Vale a mesma observação que fizemos acima para as páginas 303 e 304

$335 \quad 31$

$7 \%$

$22 \%$

$340 \quad 23$

$11 \%$

$23 \%$

page

pages 295 te 299

34034 idêntica observação que fizemos para as páginas 303 e 304 .

34125 Substituir a fórmula dada por:

$$
\frac{-\Delta P}{p^{\prime}}=\left(\frac{2 N^{\top}+N^{-}}{9 N^{\top}+N^{\top}}\right)
$$

$341 \quad 27$

$341 \quad 28$

347

354

354

13

25
$7 \%$
$22 \%$
$11 \%$
$23 \%$
A linh

(pag. ))

(pg. 263)

pag. )

pg. 263) 